\title{
Checklist of ectoparasites of cricetid and heteromyid rodents in México
}

\author{
Jessica E. Light ${ }^{1 *}$, Lance A. Durden ${ }^{2}$, Barry M. OConnor ${ }^{3}$, Whitney C. Preisser ${ }^{1}$, Roxana Acosta ${ }^{4}$ and Ralph P. Eckerlin ${ }^{5}$ \\ ${ }^{1}$ Department of Wildlife and Fisheries Sciences, Texas A\&M University, College Station, 77843, Texas, U.S.A. Email: jlight2@tamu. \\ edu (JEL); wcpreisser@gmail.com (WCP). \\ ${ }^{2}$ Department of Biology, Georgia Southern University, Statesboro, 30458, Georgia, U.S.A. Email: Idurden@georgiasouthern.edu (LAD). \\ ${ }^{3}$ Department of Ecology and Evolutionary Biology, Museum of Zoology, University of Michigan, Research Museums Center, Ann \\ Arbor, 48108, Michigan, U.S.A. Email: bmoc@umich.edu (BMOC). \\ ${ }^{4}$ Museo de Zoología, Departamento de Biología Evolutiva, Facultad de Ciencias, Universidad Nacional Autónoma de México, \\ 04510, Ciudad de México, México. Email: roxana a2003@yahoo.com.mx (RA). \\ ${ }^{5}$ Mathematics, Science, Technology and Business Division, Northern Virginia Community College, Annandale, 22003, Virginia, \\ U.S.A. Email: reckerlin@nvcc.edu (RPE). \\ ${ }^{*}$ Corresponding author
}

\begin{abstract}
We present an updated checklist of ectoparasite species (including mites, ticks, lice, and fleas) infesting cricetid and heteromyid rodents (Rodentia: Cricetidae and Heteromyidae) in México. For each parasite species, we include information on parasite taxonomy, host associations, collection localities, citations from the literature, and museum collections, when available. We recorded more than 172 mite, 114 flea, 22 tick, and 22 louse species from a minimum of 110 host species ( 82 cricetid and 28 heteromyid species) distributed across 31 states in México. This work represents the most up-to-date and comprehensive checklist of ectoparasite species parasitizing cricetid and heteromyid rodents in México.

Presentamos una lista actualizada de especies de ectoparásitos (ácaros, garrapatas, piojos y pulgas) que infestan roedores cricétidos y heterómidos (Rodentia: Cricetidae y Heteromyidae) en México. Para cada especie de parásito, incluimos información sobre la taxonomía de los parásitos, asociaciones con el hospedero, localidades de colecta, citas de la literatura y colecciones de museo, cuando están disponibles. Registramos más de 172 especies de ácaros, 114 pulgas, 22 garrapatas y 22 piojos de un mínimo de 110 especies de hospederos (82 especies de cricétidos y 28 heterómidos) distribuidas en 31 estados de México. Este trabajo representa la lista más actualizada y completa de las especies de ectoparásitos que parasitan a los roedores cricétidos y heterómidos en México
\end{abstract}

Key words: Cricetidae; fleas; Heteromyidae; Ixodida; lice; ticks; México; mites; Phthiraptera: Siphonaptera.

(c) 2020 Asociación Mexicana de Mastozoología, www.mastozoologiamexicana.org

\section{Introduction}

Of the 2,552 described species of rodents (Rodentia) worldwide (Burgin et al. 2018), over 240 species are distributed in México and 110 of those are Mexican endemics (CebaIlos and Arroyo-Cabrales 2012; Ramírez-Pulido et al. 2014). The families Cricetidae and Heteromyidae are particularly diverse in México, with approximately 150 and 40 species, respectively, representing the majority of the Mexican rodent fauna (Ceballos 2014; Burgin et al. 2018). Being so diverse, representatives of these rodent families are generally well-studied in México (e. g., Rogers et al. 2011; Fernández et al. 2012; Fernández et al. 2014; Porter et al. 2017). Notably, there have been many attempts to characterize the parasite fauna of cricetid and heteromyid rodents. Surveys of the ectoparasites (mites, ticks, lice, fleas) of Cricetidae and Heteromyidae began early and have resulted in several checklists, some for all ectoparasites (e. g., Whitaker and Morales-Malacara 2005) and others for each taxonomic group. For example, for lice Sánchez-Montes et al. (2013) and Sánchez-Montes et al. (2018) provide excellent reviews of sucking lice and chewing lice, respectively, from
México (although we note that no cricetid or heteromyid rodents are known to have chewing lice). Ferris (1951), Kim et al. (1986), and Durden and Musser (1994a, 1994b) also are good references for general host-louse lists. Hoffmann (1990) is an excellent reference summarizing the chigger (Acari: Trombiculidae) fauna from México. For fleas, useful checklists and information are included in Hopkins and Rothschild (1966), Barnes et al. (1977), Muñiz et al. (1981), Morales-Muciño and Llorente-Bousquets (1985), Morales and Llorente (1986), Ayala-Barajas et al. (1988), PonceUlloa and Llorente (1996), Acosta and Morrone (2003), Acosta et al. (2008), and Acosta (2014). Lastly, the parasite chapters in "Biology of the Heteromyidae" (Whitaker et al. 1993), "Biology of Peromyscus (Rodentia)" (Whitaker 1968) and "Biology of New World Microtus" (Timm 1985) are also good lists of all host-parasite associations (with references to original literature) for the Heteromyidae, Peromyscus, and Microtus, respectively. Preisser and Falcón-Ordaz (2019) also present a comprehensive list of all cricetid and heteromyid endoparasites known to date. All of these checklists are important for any parasitologist to 
have available when trying to identify ectoparaties of cricetid and heteromyid rodents. Given the diversity of these rodent families in México, a comprehensive list of all ectoparasties of Cricetidae and Heteormyidae is warranted, which we provide below.

To produce our checklist summarizing all major ectoparasite groups from cricetid and heteromyid species across México, we consolidated information from previously published checklists and searched for new host-parasite records. In our search of new records, we collected host-parasite records using Web of Science, using the following search terms: cricetid*/heteromyid* AND flea*/tick*/mite*/louse/ lice AND Mexico. The ectoparasite records are grouped by phylum and arranged alphabetically at the order, family, genus, and species levels. For each parasite species, we included data on taxonomic authority, host associations, collection localities, citations from the literature, and museum collections, when available. Some parasite records are newly reported here after examination of specimens in the U. S. National Tick Collection, Georgia Southern University, Statesboro, Georgia, and The Acarology Laboratory, Museum of Biological Diversity, The Ohio State University. Parasite species listed as "sp." from different localities, host species, or publications may represent different species. The host genera Chaetodipus, Dipodomys, Heteromys, and Perognathus belong to the family Heteromyidae. All other host genera belong to Cricetidae. Note that we follow the mammal taxonomy of Burgin et al. (2018) where the heteromyid genus Liomys is now recognized as Heteromys. Thus, all previous "Liomys" host associations listed below are recorded under the genus Heteromys. Abbreviations for the museum records are as follows: $\mathrm{AMNH}=$ American Museum of Natural History, New York, New York, United States (U. S.). $\mathrm{BYU}=$ Brigham Young University Flea Collection, Monte L. Bean Life Science Museum, Provo, Utah, U. S. CAIM, ISET, Indre = Colección de Artrópodos con Importancia Médica of the Instituto de Diagnóstico y Referencia Epidémiologi$\cos$ (formerly Instituto de Salubridad y Enfermedades Tropicales), Ciudad de México, México. $\mathrm{CMNH}=$ The Carnegie Museum of Natural History, Pittsburgh, Pennsylvania, U. S. CNAC = Colección Nacional de Ácaros, Instituto de Biología, Universidad Nacional Autónoma de México, Ciudad de México, México CNC = Canadian National Collections of Insects, Arachnids and Nematodes, Ottawa, Ontario, Canada. $\mathrm{CPFC}, \mathrm{LAFC}=$ Laboratorio de Acarología, Facultad de Ciencias, Universidad Nacional Autónoma de México, Ciudad de México, México. ENCB = Escuela Nacional de Ciencias Biológicas, Ciudad de México, México. FMNH = Division of Insects, Field Museum of Natural History, Chicago, Illinois, U. S. GML = Gorgas Memorial Laboratory, Panama, Panama. IBUNAM = Instituto de Biología, Universidad Nacional Autónoma de México, Ciudad de México, México. KU, SEMC, SNOW = Snow Entomological Museum, University of Kansas, Kansas, U. S. (Emerson Collection. The K.C. Emerson collection is now at Oklahoma State University in Stillwater, Oklahoma). MNHN = Muséum National
d'Histoire Naturelle, Paris, France. MHNCM = Museo de Historia Natural de la Ciudad de México, Ciudad de México, México. MWH = Personal Collection of Michael W. Hastriter, Monte L. Bean Life Science Museum, Provo, Utah, U. S. MZFC = Museo de Zoología Alfonso L. Herrera, Facultad de Ciencias, Universidad Nacional Autónoma de México, Ciudad de México, México. NMNH, USNM = National Museum of Natural History, Smithsonian Institution, Washington, D.C., U. S. NHM, BMNH = Department of Entomology, Natural History Museum, London, England OSAL = The Acarology Laboratory, Museum of Biological Diversity, The Ohio State University, Columbus, Ohio, U. S. PRICE INSTITUTE = Price Institute for Phthirapteran Research at the University of Utah, Salt Lake City, Utah, U. S. REL = Personal Collection of Robert E. Lewis, Now in the FMNH. RML = Rocky Mountain Laboratory, Hamilton, Montana, U. S. (the RML no longer has collections and all ectoparasites have been transferred to the USNM or USNTC) RPE = Personal Collection of Ralph Eckerlin, Northern Virginia Community College, Annandale, Virginia, U. S. USNTC = United States National Tick Collection, Institute of Coastal Plain Science, Georgia Southern University, Statesboro, U. S. ZISP = Zoological Institute, Russian Academy of Sciences, Saint-Petersburg, Russia.

Across nearly all (31) states in México, we document a minimum of 172 mite, 114 flea, 22 tick, and 22 louse species from at least 110 host species ( 82 cricetid and 28 heteromyid species). No ectoparasites were recorded from Aguascalientes. Across the 31 states with ectoparasites, mites, ticks, lice, and fleas are found in 27, 25, 23, and 29 of these states, respectiviely. Twenty Mexican states are documented here as having all four ectoparasite groups. Of the 82 cricetid species represented on our checklist, 53 , 25,31 , and 59 species are parasitized by mites, ticks, lice, and fleas, respectively, and 5 host species are parasitized by all four ectoparasite groups. Of the 28 heteromyid species represented on our checklist, 28, 9, 12, and 10 species are parasitized by mites, ticks, lice, and fleas, respectively, and 5 host species are parasitized by all four ectoparasite groups.

Our numbers of ectoparasite species and host associations are likely underestimates for a variety of reasons. For one, not all hosts and parasites were identified to species; thus, several undetermined parasites may represent new species or immature stages (e. g., for ticks) that were not, or could not, be identifed to species. Additionally, many cricetid and heteromyid species are not included in this checklist. With additional investigations, it is likely that more host associations will be uncovered, some of which may include new ectoparasite species. Despite these almost certain underestimates in our findings, there also is the possibility of incorrect, and thus inflated numbers of, associations due to ectoparasite contamination. During specimen processing, ectoparasites can easily become dislodged from their hosts becoming associated with the incorrect host by process of human error. Thus, we strongly encourage researchers to process each host specimen individually and carefully to avoid potential contamination (e. g., Cook 1954). 
Assembling checklists for parasites clearly reveals that more associations certainly exist; they simply are not documented and published. A potential way to document more host-parasite associations is to take all available data from host specimens in the field, including their parasites, resulting in a "holistic" or "extended" specimen (Cook et al. 2016; 2017; Webster 2017; Cook and Light 2019). Although there are exceptions (e. g., Wenzel and Tipton 1966), field mammalogists collecting specimens, especially recently, have often ignored parasite collection despite their importance (Gardner 1996; Hoberg 2002; Cook and Light 2019). We strongly advocate for the collection of holistic specimens in the field, and then deposition of these materials in the appropriate repositories as these specimens will provide much needed data about parasite faunas and distribution of those faunas such that subsequent studies can be conducted (Bell et al. 2018; Preisser and Falcón-Ordaz 2019). Lastly, we note that our checklist is almost entirely the result of summarization of the literature. However, our search of the U.S. National Tick Collection at Georgia Southern University alone resulted in a minimum of 6 previously undescribed host-parasite associations and 9 new state records. Similary, examination of the Acarology Laboratory at The Ohio State University resulted in 6 new state records and 1 new mite species and host association. Natural history collections likely hold untold numbers of additional parasite records. Therefore, future checklists should examine natural history collections holdings, which will likely result in additional host-parasite associations and locality records.

\author{
Phylum: Arthropoda von Siebold, 1848 \\ Class: Arachnida Lamarck, 1801 \\ Subclass: Acari Leach, 1817 \\ Superorder: Parasitiformes Reuter, 1909 \\ Order: Ixodida Leach, 1815
}

Family: Argasidae Koch, 1844

Argas brevipes Kohls, Hoogstraal, and Clifford, 1961

BAJA CALIFORNIA SUR: 205 km N of La Paz: Peromyscus sp. nest (USNTC). Specimens in collections: USNTC.

Argas sp.

NUEVO LEÓN: Sierra de San Antonio Peña Nevada: Peromyscus maniculatus (Tijerina-Medina et al. 2006). No specimens in collections.

\section{Ornithodoros nicollei Mooser, 1932}

COLIMA: near Colima: Hodomys alleni (Brumpt et al. $\underline{1939}$ i Cooley and Kohls 1944; Hoffmann 1962). Unknown if specimens are in collections. SONORA: Tiburón Island, Sausal Valley: Neotoma sp. (Kohls et al. 1965). Specimens in collections: USNTC. UNKNOWN LOCALITY: Hodomys alleni, Neotoma sp. (Davis 1943; Hoffmann 1962; Kohls et al. 1965). Unknown if specimens are in collections.

\section{Ornithodoros parkeri Cooley, 1936}

BAJA CALIFORNIA: near Santiago: Neotoma sp. nest (Kohls et al. 1965). Specimens in collections: USNTC.

\section{Ornithodoros talaje (Guérin-Méneville, 1849)}

(synonym: Ornithodoros dugesi Mazzotti, 1943)

BAJA CALIFORNIA SUR: $30 \mathrm{~km} \mathrm{~W}$ of La Paz; 22 miles S of La Paz: Neotoma bryanti. 98 km NW of La Paz; 4 miles W of Puerto Viejo: Neotoma sp. nest. (USNTC). Specimens in collections: USNTC. COAHUILA: near Sabinas: Neotoma micropus, Neotoma sp. nest (Mazzotti 1943; Kohls et al. 1965). Unknown if specimens are in collections. Canyon de la Fragua; 94 miles N of Saltillo: Neotoma sp. (USNTC). Specimens in collections: USNTC. NUEVO LEÓN: 9 miles $\mathrm{N}$ of Santiago: Neotoma sp. nest. (USNTC). Specimens in collections: USNTC. SAN LUIS POTOSÍ: Bocas: Neotoma leucodon nest (Mazzotti 1949; Hoffmann 1962). 78 miles N of San Luis Potosí: Neotoma sp. (USNTC). Specimens in collections: USNTC. Note: Neotoma albigula was recognized as the original host. However, according to Bradley and Mauldin (2016), N. albigula from the eastern part of Mexico is now recognized as N. leucodon. SINALOA: 12 miles $\mathrm{N}$ of Los Mochis; 31 miles $\mathrm{N}$ of Los Mochis; 5 miles $\mathrm{S}$ of Culiacán: Neotoma sp. nest. (USNTC). Specimens in collections: USNTC. SONORA: 1 mile E of Kino: Dipodomys deserti. Cholla Valley: Neotoma sp. nest. S end of Tiburón Island; Kino Nuevo; 8 miles E of Kino: Neotoma albigula. 5 miles $\mathrm{N}$ of HERMOSILLO: 8 miles W of Hermosillo; 3 miles N of Guaymas; 13 miles $\mathrm{N}$ of Guaymas; 13 miles $\mathrm{E}$ of Esperanza; 11 miles N of Navajoa: Neotoma sp., Neotoma sp. nest. (USNTC). Specimens in collections: USNTC.

\section{Ornithodoros turicata Dugès, 1876}

BAJA CALIFORNIA SUR: 17 miles S of La Paz; 4 miles W of Puerto Viejo: Neotoma sp. nest. (USNTC). Specimens in collections: USNTC.

\section{Ornithodoros (Alectorobius) sp. (near tuttlei)}

BAJA CALIFORNIA SUR: Isla Espiritu Santo, Mpio. de La Paz: Peromyscus eva (Estébanes-González and Cervantes 2005). Specimens in collections: MZFC. Note: Peromyscus eremicus was recognized as the original host. However, P. eremicus from the southern parti of the Baja California peninsula is now recognized as P. eva (Álvarez-Castañeda et al. 2010).

\section{Ornithodoros sp.}

MORELOS: 5 miles $\mathrm{N}$ of El Pachon cave: Neotoma sp. (USNTC). Specimens in collections: USNTC. UNKNOWN LOCALITY: Peromyscus difficilis (Hoffmann et al. 1989; Whitaker and Morales-Malacara 2005). Specimens in collections: Unknown; Hoffmann collection is in the CNAC.

Ixodidae Koch, 1844

Amblyomma inornatum Banks, 1909 
DURANGO: Sigmodon hispidus (Eads and Borom 1975; Guzmán-Cornejo et al. 2011). Specimens in collections: USNTC. Note: S. hispidus is not distributed in Durango according to Ceballos (2014). Possible alternative hosts include S. arizonae, S. fulviventer, or S. leucotis Ceballos (2014). Note: Eads and Borom (1975) cite Hoffmann (1962) who indicates that adult $A$. inornatum have been taken in the Mexican states of Coahuila, Morelos, Sinaloa, and Veracruz. Eads and Borom (1975) referred to an unpublished record in the USNTC (RML50471) of a single nymph that has been identified as "probably" Amblyomma inornatum. GUERRERO: Agua de Obisop: Sigmodon hispidus (USNTC). Specimens in collections: USNTC. Note: S. hispidus is not distributed in Guerrero according to Ceballos (2014). Possible alternative hosts include S. alleni, S. leucotis, or S. mascotensis (Ceballos (2014). SINALOA: 28.5 miles N of Los Mochis: Neotoma sp. (USNTC). Specimens in collections: USNTC.

\section{Amblyomma maculatum Koch, 1844}

TABASCO: Jonuta: Oryzomys sp., Sigmodon sp. (USNTC). Specimens in collections: USNTC. Note: Oryzomys sp. was recorded in the original literature but may represent Handleyomys sp.

\section{Amblyomma sp.}

CHIAPAS: $9 \mathrm{~km} \mathrm{~S}$ of Las Margagitas: Peromyscus boylii (USNTC). Specimens in collections: USNTC. Note: P. boylii is not distributed in Chiapas according to Ceballos (2014). DURANGO: $2.9 \mathrm{~km}$ SE of Atotonilco: Dipodomys ordii (USNTC). Specimens in collections: USNTC. TABASCO: Frontera: Hodomys alleni (recorded as Neotoma alleni; USNTC). Specimens in collections: USNTC. Note: H. alleni is not distributed in Tabasco according to Ceballos (2014) YUCATÁN: Heteromys gaumeri (Quintero et al. 2001; Guzmán-Cornejo et al. 2011). Specimens in collections: CNAC. UNKNOWN LOCALITY: Heteromys guameri, H. salvini (Genoways 1973; Whitaker and Morales-Malacara 2005). No specimens in collections.

Amblyomma sp. 1 and Amblyomma sp. 2

JALISCO: Chamela Biological Station: Heteromys pictus (Gómez-Rodríguez et al. 2015). Specimens in collections: CNAC. Note: Other ticks and hosts are reported in GómezRodríguez et al. (2015) from Chamela Biological Station; however, the paper is constructed in such a way that it is not possible to determine host-tick associations.

\section{Dermacentor albipictus (Packard, 1869)}

NUEVO LEÓN: Sierra de San Antonio Peña Nevada: Peromyscus boylii, P. maniculatus, Heteromys irroratus (GuzmánCornejo et al. 2016; Tijerina-Medina et al. 2006). No specimens in collections. Note: $P$. boylii is not distributed in Nuevo León according to Ceballos (2014).

\section{Dermacentor parumapertus Neumann, 1901}

DURANGO: $2.9 \mathrm{~km}$ SE of Atotonilco: Dipodomys merriami (USNTC). Specimens in collections: USNTC. SONORA: 5 miles N of Guamos: Dipodomys merriami (USNTC). Specimens in collections: USNTC.

\section{Dermacentor sp.}

BAJA CALIFORNIA SUR: San José del Cabo: Dipodomys sp. (USNTC). Specimens in collections: USNTC. DURANGO: $2.9 \mathrm{~km}$ SE of Atotonilco: Dipodomys merriami, D. ordii, Perognathus flavus (USNTC). Specimens in collections: USNTC. SAN LUIS POTOSÍ: El Salto Falls: Oryzomys sp., Sigmodon hispidus (USNTC). Specimens in collections: USNTC. Note: $S$. hispidus is not distributed in San Luis Potosi according to Ceballos (2014). A possible alternative host includes S. leucotis Ceballos (2014). Note: Oryzomys sp. was recorded in the original literature but may represent Handleyomys sp. SONORA: 89.5 miles S of Benjamin Hill: Peromyscus boylii (USNTC). Specimens in collections: USNTC.

\section{Ixodes angustus Neumann, 1899}

CHIAPAS: Cerro Tzontehuitz, 13 km NE of San Cristóbal de las Casas; San Juan Chamula: Reithrodontomys microdon, Microtus guatemalensis (Estébanes-González and Cervantes 2005; Guzmán-Cornejo et al. 2007). No specimens in collections. COAHUILA: Sabinas: Neotoma sp. nest (Hoffmann 1962; Guzmán-Cornejo et al. 2007). Specimens in collections: USNTC. OAXACA: 3 km SE of Totontepec, Totontepec: Peromyscus melanocarpus. $1 \mathrm{~km} \mathrm{~N}$ of Esperanza, Santiago Comaltepec, Distrito Ixtlán: Handleyomys alfaroi (recorded as Oryzomys alfaroi; Estébanes-González and Cervantes 2005; Guzmán-Cornejo et al. 2007). No specimens in collections. Note: Guzmán-Cornejo et al. (2007) call into question all tick identifications made by Estébanes-González and Cervantes (2005); the host-tick associations from these authors may be incorrect. UNKNOWN LOCALITY: Neotoma sp. (Hoffmann 1962; Whitaker and Morales-Malacara 2005). Specimens in collections: Unknown; Hoffmann collection is in the CNAC.

Ixodes cookei Packard, 1869

NUEVO LEÓN: 10.9 km S, 10.8 km E of San Josecito: Peromyscus sp. (Montiel-Parra et al. 2007; Guzmán-Cornejo et al. 2007). Specimens in collections: CNAC.

Ixodes eadsi Kohls and Clifford, 1964.

PUEBLA: $6 \mathrm{~km}$ E of Totimehuacán: Heteromys sp. (Guzmán-Cornejo et al. 2007). Specimens in collections: CNAC. ZACATECAS: 1 mile $\mathrm{N}$ of Santa Rosa: Heteromys irroratus (USNTC). Specimens in collections: USNTC.

Ixodes granulatus Supino, 1897

OAXACA: $1 \mathrm{~km} \mathrm{S,} 0.5 \mathrm{~km}$ W of Vista Hermosa, Santiago 
Comaltepec: Peromyscus mexicanus. 11 km SW of La Esperanza to San Isidro, Santiago Comaltepec: Handleyomys chapmani (recorded as Oryzomys chapmani; EstébanesGonzález and Cervantes 2005; Guzmán-Cornejo et al. 2007). No specimens in collections. Note: Guzmán-Cornejo et al. (2007) call into question all tick identifications made by Estébanes-González and Cervantes (2005) and note that $I$. granulatus is an exclusively SE Asian species.

Ixodes minor Neumann, 1902

SAN LUIS POTOSÍ: 8 miles W of El Naranjo: Sigmodon hispidus (USNTC). Specimens in collections: USNTC. Note: $S$. hispidus is not distributed in San Luis Potosi according to Ceballos (2014). A possible alternative host includes S. leucotis Ceballos (2014). TAMAULIPAS: Acuña: Sigmodon hispidus (USNTC). Specimens in collections: USNTC.

\section{Ixodes rubidus Neumann, 1901}

SINALOA: $5 \mathrm{~km}$ NE of Santa Lucia: Peromyscus boylii (USNTC). Specimens in collections: USNTC. Note: P. boylii is not distributed in Sinaloa according to Ceballos (2014).

Ixodes sinaloa Kohls and Clifford, 1966

COLIMA: El Cobano; 25 miles SE of San Antonio: Heteromys irroratus (USNTC). Specimens in collections: USNTC. GUERRERO: 1.4 miles E of El Cobano: Heteromys pictus (USNTC). Specimens in collections: USNTC. JALISCO: Chamela Biological Station: Heteromys pictus (Keirans and Jones 1972; Gómez-Rodríguez et al. 2015). Specimens in collections: CNAC. 10 miles NW of San Patricio; $4 \mathrm{~km} \mathrm{~W}$ of Tuxpan: H. pictus (USNTC). Specimens in collections: USNTC. NAYARIT: $32 \mathrm{~km}$ SE of Tepic: Oryzomys couesi (Kohls and Clifford 1966; Guzmán-Cornejo et al. 2007). O. palustris (Keirans and Jones 1972; Whitaker and Morales-Malacara 2005). Specimens in collections: USNTC. Note: O. palustris is not distributed in Nayarit according to Ceballos (2014). SINALOA: $5 \mathrm{~km}$ SW of San Ignacio; $1 \mathrm{~km}$ SE of Sana Lucia; $1 \mathrm{~km}$ NE of Santa Lucia; $4.8 \mathrm{~km}$ NE of Copala; $6.4 \mathrm{~km} \mathrm{SW}$ of Copala: Heteromys pictus (Kohls and Clifford 1966; Keirans and Jones 1972; Guzmán-Cornejo et al. 2007). Specimens in collections: USNTC.

Ixodes spinipalpis Hadwen and Nuttall, 1916

GUERRERO: Omiltemi; 1.6 km NW of Omiltemi: Peromyscus sp. (Guzmán-Cornejo et al. 2007). Specimens in collections: CNAC. MORELOS: Zempoala: Peromyscus sp. (GuzmánCornejo et al. 2007). Specimens in collections: CNAC. VERACRUZ: 0.8 km NE of Las Minas: Peromyscus sp. (GuzmánCornejo et al. 2007). Specimens in collections: CNAC.

Ixodes tancitarius Cooley and Kohls, 1942

MICHOACÁN: Cerro Tancítaro: Reithrodontomys sp. (Cooley and Kohls 1942; Hoffmann 1962; Whitaker and
Morales-Malacara 2005; Guzmán-Cornejo et al. 2007). Specimens in collections: USNTC. VERACRUZ: $0.8 \mathrm{~km}$ NE of Las Minas: Reithrodontomys sp. (Guzmán-Cornejo et al. 2007). Specimens in collections: CNAC.

\section{Ixodes woodi Bishopp, 1911}

COAHUILA: Sabinas: Neotoma micropus (Robbins and Keirans 1987; 1992; Guzmán-Cornejo et al. 2007). Specimens in collections: USNTC. MORELOS: Zempoala: Neotoma sp. (Guzmán-Cornejo et al. 2007). Specimens in collections: CNAC.

\section{Ixodes sp.}

CAMPECHE: 7.5 km SW of Escárcega: Sigmodon hispidus, Heteromys gaumeri (USNTC). Specimens in collections: USNTC. Note: S. hispidus is not distributed in Campeche according to Ceballos (2014). A possible alternative host includes S. toltecus Ceballos (2014). CHIAPAS: Tzontehuitz, Volcán Tacana: Reithrodontomys sumichrasti (USNTC). Specimens in collections: USNTC. COLIMA: EI Cobano: Heteromys irroratus (USNTC). Specimens in collections: USNTC. CIUDAD DE MÉXICO: Zacayuca: Peromyscus gratus (recorded as P. truei; USNTC). Specimens in collections: USNTC. GUERRERO: Omilteme: Neotoma mexicana (USNTC). Specimens in collections: USNTC. HIDALGO: $4 \mathrm{~km}$ E of San Felipe Orizatlan: Baiomys taylori. Pachuca: Peromyscus difficilis (USNTC). Specimens in collections: USNTC. JALISCO: Chamela Biological Station: Heteromys pictus (Gómez-Rodríguez et al. 2015). Specimens in collections: CNAC. MICHOACÁN: Tancitaro: Peromyscus hylocetes (USNTC). Specimens in collections: USNTC. NUEVO LEÓN: Sierra de San Antonio Peña Nevada: Peromyscus boylii (Tijerina-Medina et al. 2006). No specimens in collections. Note: P. boylii is not distributed in Nuevo León according to Ceballos (2014). PUEBLA: Matamoros: Baiomys musculus. Mata Maras: Baiomys sp. (USNTC). Specimens in collections: USNTC. TAMAULIPAS: Matamoros: Perognathus merriami (USNTC). Specimens in collections: USNTC. VERACRUZ: Texolo: Peromyscus mexicanus, Sigmodon sp. (USNTC). Specimens in collections: USNTC. YUCATÁN: 7.5 km W of Escárcega: Ototylomys phyllotis. 2 km $\mathrm{N}$ of Piste: Peromyscus yucatanicus (USNTC). Specimens in collections: USNTC. UNKNOWN LOCALITY: Peromyscus difficilis (Hoffmann et al. 1989; Whitaker and Morales-Malacara 2005). Handleyomys alfaroi (recorded as Oryzomys alfaroi), Microtus guatemalensis, P. melanocarpus, Reithrodontomys microdon (Guzmán-Cornejo et al. 2007). Heteromys guameri, H. pictus. (Genoways 1973; Whitaker and Morales-Malacara 2005). Specimens in collections: Unknown; Hoffmann collection is in the CNAC.

\footnotetext{
Phylum: Arthropoda von Siebold, 1848

Class: Arachnida Lamarck, 1801 Subclass: Acari Leach, 1817

Superorder: Parasitiformes Reuter, 1909
} 
Order: Mesostigmata Canestrini, 1891

Family: Ameroseiidae Evans, 1961

Ameroseius bassolsae (Vargas and Polaco, 2001)

UNKNOWN LOCALITY: Dipodomys nelsoni (Vargas and Polaco 2001). Unknown if specimens are in collections.

Sertitympanum contiguum Elsen and Whitaker, 1985

UNKNOWN LOCALITY: Dipodomys nelsoni (VargasSandoval et al. 1991). Unknown if specimens are in collections.

Dermanyssidae Kolenati, 1851

Liponyssoides sanguineus (Hirst, 1914)

ESTADO DE MÉXICO: Tonatico: Neotoma mexicana. Barrientos: Baiomys taylori (Hoffmann et al. 1972). Tlapacoya: Peromyscus difficilis (Bassols 1981). Unknown if specimens are in collections. PUEBLA: San Pedro Atlixco: Peromyscus sp. (Hoffmann et al. 1972). Unknown if specimens are in collections.

Laelapidae Berlese, 1892

Subfamily: Laelapinae Berlese, 1892

Androlaelaps (Androlaelaps) grandiculatus Eads, 1951

BAJA CALIFORNIA SUR: Isla Espíritu Santo, Mpio. La Paz: Chaetodipus spinatus (Estébanes-González and Cervantes 2005). Specimens in collections: IBUNAM. San José del Cabo and Loreto: C. spinatus (Bassols 1981). Unknown if specimens are in collections. SAN LUIS POTOSÍ: 12 km S, 1.5 km E Sta. Ma. del Río: Chaetodipus nelsoni. $1 \mathrm{~km}$ E Huizache; $5 \mathrm{~km}$ SW Núñez: C. penicillatus (Bassols 1981). Unknown if specimens are in collections. Note: C. penicillatus is not distributed in San Luis Potosí according to Ceballos (2014).

\section{Androlaelaps (Androlaelaps) leviculus Eads, 1951}

CIUDAD DE MÉXICO: La Venta: Peromyscus sp. (Bassols 1981). Specimens in collections: MHNCM. OAXACA: Salina Cruz: Heteromys pictus (Bassols 1981). Specimens in collections: MHNCM. SAN LUIS POTOSÍ: Sta. Ma. del Río: Onychomys torridus (Bassols 1981). Specimens in collections: MHNCM. Note: O. torridus is not distributed in San Luis Potosí according to Ceballos (2014). SONORA: 12 km NE Puerto Peñasco: Dipodomys sp. (Bassols 1981). Specimens in collections: MHNCM.

\section{Androlaelaps (Androlaelaps) setosus Fox, 1946}

CIUDAD DE MÉXICO: Churubusco: Microtus sp. (Bassols 1981). Unknown if specimens are in collections. GUERRERO: Cocula: Osgoodomys banderanus nest (Bassols 1981). Unknown if specimens are in collections. SAN LUIS POTOSÍ: 31 km NE El Salto. Reithrodontomys sp. (Bassols 1981). Unknown if specimens are in collections.
Androlaelaps (Androlaelaps) sinuosa Furman, 1954

BAJA CALIFORNIA SUR: San Ignacio El Arco: Chaetodipus rudinoris, Dipodomys sp. Desierto de Magdalena: Perognathus sp. (Bassols 1981). Unknown if specimens are in collections. Note: Chaetodipus baileyi was recognized as the original host. However, according to Riddle et al. (2000), C. baileyi from the Baja California peninsula are now recognized as C. rudinoris.

Androlaelaps (Haemolaelaps) casalis (Berlese, 1887)

COLIMA: Playa de Oro: Heteromys pictus, $H$. spectabilis (Estébanes-González et al. 2011). Specimens in collections: IBUNAM. Note: $H$. spectabilis is not distributed in Colima according to Ceballos (2014). ESTADO DE MÉXICO: Carretera Tepic-San Blas, km 20: Heteromys pictus (Bassols 1981). Unknown if specimens are in collections. Jalisco: Chamela Biological Station: Heteromys pictus (Gómez-Rodríguez et al. 2015). Specimens in collections: CNAC. NAYARIT: Carretera Tepic-San Blas, km 20: Heteromys pictus (Bassols 1981). Unknown if specimens are in collections. SAN LUIS POTOSÍ: Rancho "El Estribo," 10 km SE of El Naranjo, Mpio. Ciudad del Maíz: Sigmodon hispidus (Estébanes-González and Cervantes 2005). Specimens in collections: IBUNAM. Note: S. hispidus is not distributed in San Luis Potosí according to Ceballos (2014). A possible alternative host includes S. leucotis Ceballos (2014).

\section{Androlaelaps (Haemolaelaps) fahrenholzi (Berlese, 1911)}

CHIAPAS: $16 \mathrm{~km}$ SW Tapachula: Heteromys salvini. Tzontchuitz: Peromyscus zarhynchus (Bassols 1981). Specimens in collections: MHNCM. COLIMA: Playa de Oro: Baiomys musculus, Nyctomys sumichrasti (Estébanes-González et al. 2011). Specimens in collections: IBUNAM. CIUDAD DE MÉXICO: El Zarco; Bosque de Chapultepec: Microtus mexicanus. $2.5 \mathrm{~km}$ W Parres: Neotomodon alstoni. $1.6 \mathrm{~km} \mathrm{E}, 800 \mathrm{~m} \mathrm{~S}$ Acopilco; 5 km Meyehualco: Peromyscus difficilis. Contreras: P. melanotis. La Venta: Peromyscus sp. El Guarda: Reithrodontomys sp. (Bassols 1981). Specimens in collections: MHNCM. ESTADO DE MÉXICO: $11 \mathrm{~km} N$ Barrientos: Baiomys taylori. Teotihuacán: Heteromys irroratus. Río Frío: Microtus mexicanus nest. Río Frío Llano Grande, cerca de Ojotongo; Lagunas de Zempoala: Neotomodon alstoni. Naucalpan de Juárez: Microtus sp. Lagunas de Zempoala: Neotoma sp. Popocatépetl, 200 m W Paso de Cortés: Peromyscus maniculatus. Iztaccíhuatl: P. melanotis. Río Frío Llano Grande: P. melanotis, Peromyscus sp. (Bassols 1981). Specimens in collections: MHNCM. GUERRERO: 6 km W Colotlipa: Oryzomys palustris (Bassols 1981). Specimens in collections: MHNCM. Note: O. palustris is not distributed in Guerrero according to Ceballos (2014). HIDALGO: Xoxali: Peromyscus melanophrys, P. gratus (recorded as P. truei), Dipodomys ordii. Parque Nacional El Chico: Microtus mexicanus (Bassols 1981). Specimens in collections: MHNCM. MORELOS: Tepoztlán: Baiomys musculus (Bassols 1981). Specimens in collections: MHNCM. JALISCO: 1 km S Acatlán: Heteromys irroratus (Bassols 1981). Specimens in collections: 
MHNCM. OAXACA: 3 km SE of Totontepec, Mpio. Totontepec: Peromyscus melanocarpus (Estébanes-González and Cervantes 2005). Specimens in collections: IBUNAM. $12 \mathrm{~km} \mathrm{NW}$ Tehuantepec: Heteromys pictus. Llano de las Flores: Microtus mexicanus. 7 km SW Suchixtepec; 16 km SW Suchixtepec: $P$. boylii, Reithrodontomys sumichrasti. Huajuapan de León: $P$. gratus (recorded as P. truei; Bassols 1981). Specimens in collections: MHNCM. Note: P. boylii is not distributed in Oaxaca according to Ceballos (2014). SONORA: Puerto Peñasco; Rancho Noche Buena; Guaymas: Dipodomys sp. 12 km NE Puerto Peñasco: Onychomys sp. (Bassols 1981). Specimens in collections: MHNCM. SAN LUIS POTOTSÍ: Rancho "El Estribo," 10 km SE of El Naranjo, Mpio. Ciudad del Maíz: Sigmodon hispidus (Estébanes-González and Cervantes 2005). Specimens in collections: IBUNAM. Note: S. hispidus is not distributed in San Luis Potosí according to Ceballos (2014). A possible alternative host includes S. leucotis (Ceballos 2014). VERACRUZ: 18 km NW of Teocelo, Mpio. Ixhuacán; $5 \mathrm{~km}$ W of Naolinco, Mpio. Naolinco: Microtus quasiater (Estébanes-González and Cervantes 2005). Specimens in collections: IBUNAM. Cofre de Perote: Neotomodon alstoni, Peromyscus sp. 4 km N Jilotepec: Peromyscus leucopus. San Andrés Tuxtla: Heteromys pictus (Bassols 1981). Specimens in collections: MHNCM.

\section{Eubrachylaelaps circularis (Ewing, 1933)}

CHIAPAS: Peromyscus levipes (recorded as P. boylii levipes), $P$. oaxacensis (Furman 1955b). Unknown if specimens are in collections. Presa Raudales: P. mexicanus. Tzontehuitz: P. zarhynchus, Reithrodontomys sumichrasti. 16 km SWTapachula:Sigmodon hispidus (Bassols 1981). Specimens in collections: MHNCM. Note: S. hispidus are not distributed in Chiapas according to Ceballos (2014). Possible alternative hosts include S. hirsutus, S. mascotensis, S. toltecus, or S. zanjonensis (Ceballos 2014). Similarly, P. levipes in not distributed in Chiapas according to Ceballos (2014). Possible alternative hosts include P. aztecus, P. beatae, P. guatamalensis, P. gymnotis, P. leucopus, P. melanophrys, P. mexicanus, P. oaxacensis, or P. zarhynchus (Ceballos 2014). CIUDAD DE MÉXICO: Ciudad de México: Peromyscus sp., Neotomodon sp. (Furman 1955b). Unknown if specimens are in collections. Note: Neotomodon sp. likely refers to Neotomodon alstoni, as this is the only species in the genus ( $\mathrm{N}$. orizabae and $N$. perotensis were synonymized with $N$. alstoni). $5 \mathrm{~km}$ Meyehualco; 1.6 km E Acopilco: Peromyscus difficilis. La Venta: $P$. hylocetes. Contreras: P. melanotis. Pedregal de San Ángel, Ciudad Universitaria: P. gratus (recorded as P. truei; Bassols 1981). Specimens in collections: MHNCM. ESTADO DE MÉXICO: $1 \mathrm{~km}$ N Barrientos: Baiomys taylori. Popocatépetl: Microtus sp., Peromyscus melanotis. Lagunas de Zempoala: P. maniculatus (Bassols 1981). Specimens in collections: MHNCM. GUERRERO: Omiltemi: Peromyscus megalops (Bassols 1981). Specimens in collections: MHNCM. JALISCO: Huascato: Heteromys irroratus (Bassols 1981). Specimens in collections: MHNCM. OAXACA: 6 $\mathrm{km}$ E of Esperanza, Mpio. Santiago Comaltepec, Distrito de Ixtlán; Cerro Zempoatepetl, 4 km E of Santa María Yacochi, Mpio. Tlahuitoltepec; 8 km S of Esperanza, Mpio. Santiago Comaltepec; 3 km E of Santa María Yacochi, Mpio. Tlahuitoltepec: Pero- myscus melanocarpus. Cerro Zempoatépetl, $4.5 \mathrm{~km} \mathrm{~N}$ of Santa María Yacochi, Mpio. Tlahuitoltepec: P. melanocarpus, Oryzomys couesi, Habromys lepturus. $3 \mathrm{~km}$ SE of Totontepec, Mpio. Totontepec: P. aztecus, P. melanocarpus, Reithrodontomys mexicanus. $1 \mathrm{~km}$ S of Vista Hermosa, Mpio. Santiago Comaltepec: $P$. melanocarpus, P. mexicanus. $11 \mathrm{~km}$ SW of Esperanza, San Isidro, Mpio. Santiago Comaltepec: Handleyomys alfaroi (recorded as O. alfaroi; Estébanes-González and Cervantes 2005). Specimens in collections: IBUNAM. Cerro Guiengola: Peromyscus sp. Llano de las Flores: R. sumichrasti (Bassols 1981). Specimens in collections: MHNCM. PUEBLA: 10 km San Martín Texmelucan, Mpio. San Martín Texmelucan: Peromyscus maniculatus (Estébanes-González and Cervantes 2005). Specimens in collections: IBUNAM. Atlixco: P. difficilis. (Bassols 1981). Specimens in collections: MHNCM.

\section{Eubrachylaelaps debilis Jameson, 1950}

CIUDAD DE MÉXICO: Peromyscus sp. (Furman 1955b). Unknown if specimens are in collections. ESTADO DE MÉXICO: $11 \mathrm{~km} \mathrm{~N}$ de Barrientos: Baiomys taylori. San Cayetano: Peromyscus maniculatus. Iztaccíhuatl: P. melanotis. Vertiente occidental del Popocatépetl: Peromyscus sp. (Bassols 1981). Unknown if specimens are in collections. MICHOACÁN: Peromyscus sp. (Furman 1955b). Unknown if specimens are in collections.

\section{Eubrachylaelaps jamesoni Furman, 1955}

CHIAPAS: Cerro del Cañón del Sumidero, 19 km from Tuxtla Gutiérrez: Peromyscus mexicanus (Furman 1955b). Specimens in collections: USNM.

\section{Eubrachylaelaps martini Jameson, 1951}

CIUDAD DE MÉXICO: Ajusco: Neotomodon alstoni (Jameson 1951). Specimens in collections: USNM. Km 42 between Ciudad de México and Cuernavaca; Parres: N. alstoni. La Venta, 2 km SW caseta de policía: Peromyscus maniculatus (Furman 1955b). Unknown if specimens are in collections. ESTADO DE MÉXICO: Llano Grande; Río Frío; Carretera a Cuernavaca km 41-43: Neotomodon alstoni. Zoquiapan: Peromyscus sp. (Furman 1955b). Unknown if specimens are in collections. MICHOACÁN: Peromyscus hylocetes (Jameson 1951). Specimens in collections: USNM. MORELOS: Tepoztlán: Baiomys musculus (Bassols 1981). Specimens in collections: MHNCM. VERACRUZ: Cofre de Perote: Neotomodon alstoni (Furman 1955b). Unknown if specimens are in collections.

\section{Eubrachylaelaps rotundus Fonseca, 1937}

GUERRERO: Omiltemi: Peromyscus megalops (Bassols 1981). Specimens in collections: MHNCM. OAXACA: $8 \mathrm{~km}$ $\mathrm{S}$ of Esperanza, Mpio. Santiago Comaltepec: Peromyscus melanocarpus. $11 \mathrm{~km}$ SW of Esperanza, San Isidro, Mpio. Santiago Comaltepec: Handleyomys alfaroi (recorded as Oryzomys alfaroi; Estébanes-González and Cervantes 2005). 
Specimens in collections: IBUNAM. $7 \mathrm{~km}$ SW Suchixtepec: P. boylii (Bassols 1981). Specimens in collections: MHNCM. Note: $P$. boylii is not distributed in Oaxaca according to Ceballos (2014).

\section{Eubrachylaelaps spinosus Furman, 1955}

COLIMA: Playa de Oro: Osgoodomys banderanus (Estébanes-González et al. 2011). Specimens in collections: IBUNAM. GUERRERO: 4 km N Zacatula; Cocula; Gruta de Juxtlahuaca; Colotlipa: Osgoodomys banderanus (recorded as Peromyscus banderanus). Cacahuamilpa: Peromyscus sp. (Bassols 1981). Unknown if specimens are in collections. JALISCO: Chamela Biological Station: Heteromys pictus (Gómez-Rodríguez et al. 2015). Specimens in collections: CNAC, IBUNAM. MICHOACÁN: 4 mi E Apatzingán: Peromyscus sp. (Furman 1955b). Specimens in collections: FMNH, MNHM, NHM, USNM.

\section{Gigantolaelaps boneti Bassols de Barrera, 1970}

CHIAPAS: $10 \mathrm{~km} \mathrm{~N}, 15 \mathrm{~km}$ E de Raudales: Handleyomys melanotis (recorded as Oryzomys melanotis; Bassols 1981). Specimens in collections: MHNCM. Note: H. melanotis is not distributed in Chiapas according to Ceballos (2014). GUERRERO: Omiltemi: Oligoryzomys fulvescens (recorded as Oryzomys fulvescens; Bassols 1981). Specimens in collections: MHNCM. OAXACA: 1 km S Vista Hermosa, Mpio. Santiago Comaltepec: Peromyscus mexicanus. $11 \mathrm{~km} \mathrm{~N}$ Esperanza, San Isidro, Mpio. Santiago Comaltepec; 1 km N Esperanza, Mpio. Santiago Comaltepec, distrito de Ixtlán: Handleyomys alfaroi (recorded as Orzyomys alfaroi). $11 \mathrm{~km}$ SW Esperanza, San Isidro, Mpio. Santiago Comaltepec: $H$. alfaroi (recorded as O. alfaroi), Megadontomys cryophilus. Km 134 Tuxtepec-Oaxaca, 13 km W of Atepec, Mpio. Atepec: P. melanocarpus. Cerro Zempoaltepetl $4.5 \mathrm{~N}$ of Santa María Yacochi, Mpio. Tlahuitoltpec: O. couesi (EstébanesGonzález and Cervantes 2005). Specimens in collections: IBUNAM. San Juan Lachao: Handleyomys alfaroi (recorded as Oryzomys alfaroi; Bassols de Barrera 1970; Bassols 1981). Specimens in collections: ENCB, MHNCM. VERACRUZ: El Cedeño, Jalapa: Peromyscus sp. (Bassols 1981). Specimens in collections: MHNCM.

\section{Laelaps kochi Oudemans, 1936}

CIUDAD DE MÉXICO: El Zarco; Bosque de Chapultepec: Microtus mexicanus (Bassols 1981). Specimens in collections: MHNCM. HIDALGO: Cerro las Ventanas; Parque Nacional El Chico: Microtus mexicanus (Bassols 1981). Specimens in collections: MHNCM. VERACRUZ: $18 \mathrm{~km}$ NW of Teocelo, Mpio. Ixhuacán; 5 km W of Naolinco, Mpio. Naolinco: Microtus quasiater. Baderillas 6 km NW of Xalapa, Mpio. Xalapa: Peromyscus furvus (Estébanes-González and Cervantes 2005). Specimens in collections: IBUNAM. Jilotepec: P. leucopus (Bassols 1981). Specimens in collections: MHNCM.

\section{Laelaps nuttalli Hirst, 1915}

OAXACA: 6 km E of Esperanza, Mpio. Santiago Comaltepec, distrito Ixtlán; $11 \mathrm{~km}$ SW of Esperanza to San Isidro, Mpio. Santiago Comaltepec: Peromyscus melanocarpus, Handleyomys alfaroi (recorded as Oryzomys alfaroi). $1 \mathrm{~km} \mathrm{~S}$ of Vista Hermosa, Mpio. Santiago Comaltepec: P. mexicanus. $1 \mathrm{~km} \mathrm{~N}$ of Esperanza, Mpio. Santiago Comaltepec, distrito Ixtlan: H. alfaroi (recorded as O. alfaroi; Estébanes-González and Cervantes 2005). Specimens in collections: IBUNAM. VERACRUZ: $18 \mathrm{~km}$ NW of Teocelo, Mpio. Ixhuacán; $5 \mathrm{~km}$ W of Naolinco, Mpio. Naolinco: Microtus quasiater (EstébanesGonzález and Cervantes 2005). Specimens in collections: IBUNAM. Note: Laelaps nuttalli is a specific parasite of Rattus sp. The host associations above may be accidental occurrences or misidentifications.

\section{Laelaps oryzomydis Pratt and Lane, 1953}

COLIMA: Playa de Oro: Oryzomys couesi, Handleyomys melanotis (recorded as O. melanotis; Estébanes-González et al. 2011). Specimens in collections: IBUNAM. Laelaps pilifer Tipton, Altman and Keegan, 1966. OAXACA: $11 \mathrm{~km} \mathrm{SW}$ of Esperanza to San Isidro, Mpio. Santiago Comaltepec: Handleyomys alfaroi (recorded as Oryzomys alfaroi; EstébanesGonzález and Cervantes 2005). Specimens in collections: IBUNAM.

\section{Steptolaelaps heteromys Bassols, 1975}

CHIAPAS: Tapachula: Heteromys salvini (Bassols 1981). Unknown if specimens are in collections. OAXACA: $1 \mathrm{~km} \mathrm{~N}$ of Esperanza, Mpio. Santiago Comaltepec, distrito Ixtlán: Heteromys desmarestianus. $11 \mathrm{~km}$ SW of Esperanza to San Isidro, Mpio. Santiago Comaltepec: Handleyomys alfaroi (recorded as Oryzomys alfaroi). (Estébanes-González and Cervantes 2005). Specimens in collections: IBUNAM.

\section{Steptolaelaps liomydis (Grant, 1947)}

BAJA CALIFORNIA SUR: San José del Cabo: Chaetodipus spinatus (Bassols 1981). Specimens in collections: MHNCM. CHIAPAS: Tuxtla; Río San Gregorio at Pan-American Highway: Heteromys pictus (Furman 1955a). Unknown if specimens are in collections. CHIHUAHUA: La Cieneguilla: Heteromys irroratus (Bassols 1981). Specimens in collections: MHNCM. COLIMA: Playa de Oro: Heteromys pictus, $H$. spectabilis (EstébanesGonzález et al. 2011). Specimens in collections: IBUNAM. Note: $H$. spectabilis is not distributed in Colima according to Ceballos (2014). CIUDAD DE MÉXICO: Cerro Zacatepec: Peromyscus gratus (recorded as P. truei; Bassols 1981). Specimens in collections: MHNCM. ESTADO DE MÉXICO: Teotihuacán, 7.6 km S de Jiménez: Heteromys irroratus. 2 km N Tlalnepantla: Heteromys sp. (Bassols 1981). Specimens in collections: MHNCM. GUERRERO: 4 km NE Colotlipa: Heteromys pictus. Cocula: Heteromys sp. (Bassols 1981). Specimens in collections: MHNCM. JALISCO: Rancho "Laurel," $1.5 \mathrm{~km} \mathrm{~S}$ of Contla, Mpio. Tamazula de Gordiano; Rancho "La Lagunita," 5 km SW 
of Epenche, Mpio. Mazamita: Heteromys spectabilis (EstébanesGonzález and Cervantes 2005). Specimens in collections: IBUNAM. Chamela Biological Station: H. pictus (Gómez-Rodríguez et al. 2015). Specimens in collections: CNAC. Encarnación de Diaz: H. irroratus (Grant 1947). Unknown if specimens are in collections. Acatlán: Heteromys sp. (Bassols 1981). Specimens in collections: MHNCM. Note: Additional specimens reported in Furman (1955a), but specimens were lost. MICHOACÁN: Pátzcuaro: Heteromys irroratus (Furman 1955a). Unknown if specimens are in collections. NAYARIT: Km 20 Carretera TepicSan Blas: Heteromys pictus (Bassols 1981). Specimens in collections: MHNCM. OAXACA: Cerro San Felipe; Monte Albán: Heteromys irroratus (Furman 1955a). Unknown if specimens are in collections. $7.6 \mathrm{~km}$ NE de Tehuantepec; 9 km NE de Tehuantepec; Cerro Guiengola; 8 km NE Salina Cruz: H. pictus. San Juan Lachao: Oligoryzomys fulvescens (Bassols 1981). Specimens in collections: MHNCM. PUEBLA: Totimihuacán: Heteromys sp. (Bassols 1981). Specimens in collections: MHNCM. SAN LUIS POTOSÍ: Rancho “El Estribo," 10 km SE of El Naranjo, Mpio. Cuidad del Maíz: Sigmodon hispidus (Estébanes-González and Cervantes 2005). Specimens in collections: IBUNAM. Note: S. hispidus is not distributed in San Luis Potosí according to Ceballos (2014). A possible alternative host includes S. leucotis Ceballos (2014). 12 km SE Santa María del Rio: Heteromys irroratus. 2 km NE El Salto: Reithrodontomys sp. (Bassols 1981). Specimens in collections: MHNCM. VERACRUZ: San Andrés Tuxtla: Heteromys pictus (Furman 1955a). Unknown if specimens are in collections. Catemaco; $14 \mathrm{~km}$ NE Catemaco: $H$. pictus (Bassols 1981). Specimens in collections: MHNCM.

Subfamily: Haemogamasinae

Brevisterna utahensis (Ewing, 1933)

HIDALGO: Xoxafí: Peromyscus melanophrys (Hoffmann et al. 1972). Unknown if specimens are in collections.

\section{Eulaelaps stabularis (Koch, 1836)}

OAXACA: 16 km SW de Suchixtepec: Peromyscus boylii (Hoffmann et al. 1972). Unknown if specimens are in collections. Note: $P$. boylii is not distributed in Oaxaca according to Ceballos (2014).

\section{Haemogamasus ambulans (Thorrell, 1872)}

CIUDAD DE MÉXICO: E. Zarco: Microtus mexicanus (Bassols 1981). Specimens in collections: MHNCM. ESTADO DE MÉXICO: Salazar: Microtus sp. Río Frío: M. mexicanus (Bassols 1981). Specimens in collections: MHNCM. VERACRUZ: $5 \mathrm{~km} \mathrm{~W}$ of Naolinco, Mpio. Naolinco: Microtus quasiater (Estébanes-González and Cervantes 2005). Specimens in collections: IBUNAM.

Haemogamasus keegani (Jameson, 1952)

CIUDAD DE MÉXICO: 8.4 mi E Amecameca: Peromyscus melanotis (Jameson 1952). Unknown if specimens are in collections.
Haemogamasus liponyssoides Ewing, 1925

CHIAPAS: No data. Known hosts are mainly small rodents, likely cricetid and heteromyid rodents (Radovsky 1960). Unknown if specimens are in collections.

\section{Ischyropoda armatus Keegan, 1951}

BAJA CALIFORNIA SUR: Santo Domingo; Desierto de Magdalena: Chaetodipus sp. (Hoffmann et al. 1972). Specimens in collections: Unknown; Hoffmann collection is in the CNAC. HIDALGO: Xoxafí: Dipodomys ordii (Hoffmann et al. 1972). Specimens in collections: Unknown; Hoffmann collection is in the CNAC. SAN LUIS POTOSÍ: Santa María del Río: Onychomys sp. (Hoffmann et al. 1972). Specimens in collections: Unknown; Hoffmann collection is in the CNAC.

\section{Ischyropoda spiniger Keegan, 1951}

BAJA CALIFORNIA SUR: San José del Cabo: Chaetodipus spinatus. Estero Salinas; Bahía Magdalena: C. arenarius (Hoffmann et al. 1972). Specimens in collections: Unknown; Hoffmann collection is in the CNAC.

\section{Hirstionyssinae}

Echinonyssus alvarezi (Bassols-Batalla et al., 1991; QuinteroMartinez, Moreno-Moreno and Vessi-Lobato, 1991)

CHIAPAS: Palenque: Peromyscus mexicanus (BassolsBatalla et al. 1991). Specimens in collections: ENCB.

\section{Echinonyssus galindoi (Strandtmann and Yunker, 1966)}

CIUDAD DE MÉXICO: Contreras: Peromyscus melanotis. Bosque de Chapultepec: Microtus mexicanus (Bassols 1981). Specimens in collections: MHNCM. ESTADO DE MÉXICO: San Cayetano; Ajusco: Peromyscus maniculatus. Iztaccíhuatl: P. melanotis. Zoquiapan: Peromyscus sp. Naucalpan de Juárez: Microtus sp. (Bassols 1981). Specimens in collections: MHNCM. GUERRERO: Omiltemi: Peromyscus megalops (Bassols 1981). Specimens in collections: MHNCM. HIDALGO: Cerro las Ventanas; Parque Nacional El Chico: Microtus mexicanus. (Bassols 1981). Specimens in collections: MHNCM. MORELOS: Derrame del Chichinautzin: Peromyscus difficilis (Bassols 1981). Specimens in collections: MHNCM. OAXACA: $1 \mathrm{~km} \mathrm{~N}$ of Esperanza, Mpio. Santiago Comaltepec, distrito Ixtlán: Reithrodontomys mexicanus (Estébanes-González and Cervantes 2005). Specimens in collections: IBUNAM. Llano de las Flores: Habromys lepturus (recorded as Peromyscus lepturus; Bassols 1981). Specimens in collections: MHNCM. PUEBLA: Chiautzingo: Peromyscus maniculatus, P. melanotis, Reithrodontomys chrysopsis, Heteromys irroratus (Ramírez et al. 1980). Unknown if specimens are in collections. NE Chignahuapan: P. boylii, P. leucopus, $R$. sumichrasti. Ahuazotepec: P. maniculatus, $R$. megalotis (Bassols-Batalla et al. 1991). Specimens in collections: ENCB. Note: P. boylii is not distributed in Puebla according to Ceballos (2014). 
Echinonyssus hilli (Jameson, 1950)

BAJA CALIFORNIA SUR: Loreto: Chaetodipus spinatus (Bassols et al. 1976). Unknown if specimens are in collections.

\section{Echinonyssus incomptis (Strandtmann and Morlan,} 1953).

PUEBLA: San Cristóbal el Seco: Dipodomys phillipsi (Hoffmann et al. 1972). Specimens in collections: Unknown; Hoffmann collection is in the CNAC. SONORA: Caborca: Dipodomys sp. (Bassols 1981). Unknown if specimens are in collections.

Echinonyssus isabelae Estébanes and Smiley, 1977

VERACRUZ: 18 km NW of Teocelo, Mpio. Ixhuacán; $5 \mathrm{~km} \mathrm{~W}$ of Naolinco, Mpio. Naolinco: Microtus quasiater (Estébanes-González and Cervantes 2005). Specimens in collections: IBUNAM.

Echinonyssus liomys (Herrin and Yunker, 1973)

MICHOACÁN: Caleta de Campos: Heteromys pictus (Bassols-Batalla et al. 1991). Unknown if specimens are in collections. NAYARIT: San Blas: Heteromys pictus (Bassols-Batalla et al. 1991). Unknown if specimens are in collections.

Echinonyssus microchelae (Strandtmann and Yunker, 1966)

COLIMA: Playa de Oro: Heteromys pictus, H. spectabilis (Estébanes-González et al. 2011). Specimens in collections: IBUNAM. Note: $\mathrm{H}$. spectabilis is not distributed in Colima according to Ceballos (2014). PUEBLA: Pahuatlán: Peromyscus leucopus (Bassols-Batalla et al. 1991). Unknown if specimens are in collections.

Echinonyssus neotomae (Eads and Hightower, 1951)

MORELOS: Cerro del Chichinautzin: Neotoma mexicana (Bassols 1981). Unknown if specimens are in collections.

Echinonyssus teresae Estébanes and Smiley, 1997

OAXACA: Llano de las Flores, Km 132; Tuxtepec-Oaxaca, Mpio. Atepec; $11 \mathrm{~km} \mathrm{SW}$ of Esperanza to San Isidro, Mpio. Santiago Comaltepec: Microtus mexicanus (EstébanesGonzález and Cervantes 2005). Specimens in collections: IBUNAM.

\section{Echinonyssus triacanthus (Jameson, 1950)}

SONORA: Caborca: Dipodomys sp. (Bassols 1981). Unknown if specimens are in collections.

Echinonyssus utahensis (Allred and Beck, 1966)

BAJA CALIFORNIA: San Quintín: Peromyscus fraterculus (Herrin 1970). Specimens in collections: Collection of F. J. Radovsky, whereabouts unknown. Note: P. fraterculus is not distributed in Baja California according to Ceballos
(2014). ESTADO DE MÉXICO: El Zarco: Microtus mexicanus (Hoffmann et al. 1972). Specimens in collections: Unknown; Hoffmann collection is in the CNAC.

Macrochelidae Vitzthum, 1930

Macrocheles hechti Machado, 1964

CIUDAD DE MÉXICO: El Zarco: Reithrodontomys megalotis (Hoffmann et al. 1972). Specimens in collections: Unknown; Hoffmann collection is in the CNAC.

\section{Macrocheles sp.}

CIUDAD DE MÉXICO: El Zarco: Microtus mexicanus, Reithrodontomys megalotis (Bassols 1981). Unknown if specimens are in collections. HIDALGO: Cerro Las Ventanas, Parque Nacional El Chico: Microtus mexicanus (Bassols 1981). Unknown if specimens are in collections. SAN LUIS POTOSÍ: Rancho "El Estribo," 10 km SE of El Naranjo, Mpio. Ciudad del Maíz: Sigmodon hispidus (Estébanes-González and Cervantes 2005). Specimens in collections: IBUNAM. Note: S. hispidus is not distributed in San Luis Potosí according to Ceballos (2014). A possible alternative host includes S. leucotis (Ceballos 2014).

Macronyssidae Oudemans, 1936

Ornithonyssus bacoti (Hirst, 1913)

COLIMA: Playa de Oro: Oryzomys couesi (EstébanesGonzález et al. 2011). Specimens in collections: IBUNAM. SAN LUIS POTOSÍ: Rancho "El Estribo," 10 km SE of El Naranjo, Mpio. Ciudad del Maíz: Sigmodon hispidus (EstébanesGonzález and Cervantes 2005). Specimens in collections: IBUNAM. Note: S. hispidus is not distributed in San Luis Potosí according to Ceballos (2014). A possible alternative host includes S. leucotis (Ceballos 2014).

\section{Ornithonysus sp.}

JALISCO: Chamela Biological Station: Heteromys pictus (Gómez-Rodríguez et al. 2015). Specimens in collections: CNAC.

Acariformes Zachvatkin, 1952

Trombidiformes Reuter, 1909

Suborder Prostigmata Kramer, 1877

Myobiidae Mégnin, 1877

Radfordia megadontomys Bochkov and Guzmán-Cornejo, 2014

GUERRERO: Puerto del Gallo, Gral. Heliodoro Castillo: Megadontomys thomasi (Bochkov and Guzmán-Cornejo 2014). Specimens in collections: CNAC.

Radfordia peromyscus Bochkov and Guzmán-Cornejo, 2014 GUERRERO: Puerto del Gallo, General Heliodoro Cas- 
tillo: Peromyscus megalops (Bochkov and Guzmán-Cornejo 2014). Specimens in collections: CNAC, ZISP.

\section{Radfordia subuliger Ewing, 1938}

GUERRERO: Puerto del Gallo, General Heliodoro Castillo: Peromyscus beatae, Reithrodontomys sumichrasti (Bochkov and Guzmán-Cornejo 2014). Unknown if specimens in collections: Unknown, possibly CNAC. JALISCO: San Gabriel, Puerto El Floripondio: Reithrodontomys sumichrasti (Bochkov and Guzmán-Cornejo 2014). Unknown if specimens in collections: Unknown, possibly CNAC.

\section{Radfordia sp.}

OAXACA: Cerro Zempoaltépetl, $5 \mathrm{~km} \mathrm{~N}$ of Santa María Yacochi, Mpio. Tlahuitoltepec: Peromyscus sp. (EstébanesGonzález and Cervantes 2005). Specimens in collections: IBUNAM.

\section{Scutacaridae Oudemans, 1916}

Imparipes cupes Delfinado and Baker, 1978

BAJA CALIFORNIA SUR: Isla Espíritu Santo, Zona Sur, Mpio. La Paz: Chaetodipus spinatus. (Estébanes-González and Cervantes 2005). Specimens in collections: IBUNAM.

Tetranychidae Donnadieu, 1875

Pseudobryobia drummondi (Ewing, 1826)

VERACRUZ: 5 km W of Naolinco, Mpio. Naolinco: Peromyscus levipes (Estébanes-González and Cervantes 2005). Specimens in collections: IBUNAM. Note: This is an accidental occurrence as $P$. drummondi is a plant feeding mite.

Superfamily: Trombiculoidea Ewing, 1944

Trombiculidae Ewing, 1944

Trombiculinae Ewing, 1944

Crypticula jacalae (Loomis and Webb, 1972)

HIDALGO: 13 km NE Jacala: Peromyscus boylii (Loomis and Webb 1972). Specimens in collections: FMNH, OSAL, USNM.

Euschoengastoides annectens Loomis, 1971

SONORA: 1 km NE Álamos: Chaetodipus artus. 13 km SSE Álamos: Peromyscus fraterculus, C. artus, C. pernix. $16 \mathrm{~km} \mathrm{SE}$ Álamos; 22 km W Álamos: C. pernix. La Aduana: C. goldmani. 6 km N Navojoa: P. fraterculus, C. goldmani (Loomis 1971). Specimens in collections: FMNH, OSAL, USNM.

\section{Euschoengastoides arizonae Loomis, 1971}

BAJA CALIFORNIA: 48 km S San Felipe: Chaetodipus penicillatus (Loomis 1971). Specimens in collections: $F M N H$, USNM. BAJA CALIFORNIA SUR: 24 km S El Arco: Chaetodipus rudinoris (Loomis 1971). Specimens in collections:
FMNH, USNM. Note: Chaetodipus baileyi was recognized as the original host. However, according to Riddle et al. (2000), C. baileyi from the Baja California peninsula are now recognized as C. rudinoris. CHIHUAHUA: $106 \mathrm{~km}$ S Hidalgo del Parral: Dipodomys ordii (Loomis 1971). Specimens in collections: FMNH, USNM. COAHUILA: 27 km E Cuatro Ciénegas: Chaetodipus hispidus (Loomis 1971). Specimens in collections: FMNH, USNM. SONORA: 15 km SW Agua Prieta: Chaetodipus intermedius, C. penicillatus, Dipodomys merriami. 18 km W Álamos: D. merriami. 13 km W Álamos: Heteromys pictus. $3 \mathrm{~km}$ SSE Álamos; $6 \mathrm{~km}$ SSE Álamos: C. goldmani. 13 km SSE Álamos: Peromyscus fraterculus, C. artus, C. pernix. Carbo; 8 km NW Guaymas; 8 km NW Guaymas: $C$. penicillatus. 21 km E Carbo; 8 km W El Novillo; 58 km N Quitovac: C. baileyi. El Novillo: C. goldmani, C. pernix. $15 \mathrm{~km} \mathrm{NW}$ Guaymas: Onychomys torridus, P. fraterculus, C. penicillatus. 10 km S Hermosillo: P. fraterculus. Bahia Kino: C. intermedius. La Aduana; 3 km W Macuzari: C. pernix. 8 km S Naco: $O$. leucogaster, D. merriami. 81 km SE San Luis: C. penicillatus, D. merriami. 24 km W Sonoyta: O. torridus. Tajitos: C. intermedius, C. penicillatus (Loomis 1971). Specimens in collections: FMNH, USNM. Note: O. leucogaster is not distributed in Sonora according to Ceballos (2014).

\section{Euschoengastoides expansellus Loomis, 1971}

SINALOA: 22 km N Culiacán: Chaetodipus artus, C. pernix, Heteromys pictus. $18 \mathrm{~km}$ S Guamuchil: C. pernix. $13 \mathrm{~km}$ NW Guamuchil: C. artus (Loomis 1971). Specimens in collections: FMNH, OSAL, USNM. SONORA: 97 km S Navojoa: Chaetodipus goldmani (Loomis 1971). Specimens in collections: FMNH, USNM.

Euschoengastoides imperfectus (Brennan and Jones, 1954)

BAJA CALIFORNIA: $3 \mathrm{~km} \mathrm{~N}$ Puertecitos: Chaetodipus formosus (Loomis 1971). Specimens in collections: FMNH, USNM. SONORA: 25 km WSW Agua Prieta: Chaetodipus intermedius, C. penicillatus (Loomis 1971). Specimens in collections: $F M N H$, USNM.

Euschoengastoides loomisi (Crossley and Lipovsky, 1954)

COAHUILA: No data. Known hosts are mainly small rodents, likely cricetid and heteromyid rodents (Loomis 1956). Specimens in collections: SEMC.

\section{Euschoengastoides neotomae Loomis, 1971}

BAJA CALIFORNIA: Punta Banda: Peromyscus fraterculus. Isla de Salsipuedes: P. interparietalis. 13 km SE El Rosarito: Neotoma bryanti (Loomis 1971). Specimens in collections: FMNH, USNM. Note: P. eremicus was recognized as the original host. However, P. eremicus from the northern part of the Baja California peninsula is now recognized as $P$. fraterculus (Álvarez-Castañeda et al. 2010). P. guardia was recorded as the original host from Isla de Salsipuedes; however, P. guardia is not known to occur on this island and the most likely 
host is $P$. interparietalis (Ceballos 2014). N. lepida was recognized as the original host. However, all Neotoma from the Baja California peninsula are now recognized as N. bryanti (Patton et al. 2007). BAJA CALIFORNIA SUR: $11 \mathrm{~km} \mathrm{~N}$ Comandú; 5 km N San Antonio; 3 km S San Antonio: Peromyscus eva. 24 km S El Arco: P. eva, Chaetodipus rudinoris. 27 km W Santa Rosalía: C. rudinoris (Loomis 1971). Specimens in collections: FMNH, USNM. Note: C. baileyi was recognized as the original host. However, according to Riddle et al. (2000), C. baileyi from the Baja California peninsula are now recognized as $C$. rudinoris. P. eremicus from the northern part of the Baja California peninsula is now recognized as P. eva (Patton et al. 2007). SONORA: 13 km NW Cananea: Peromyscus boylii. El Novillo; 8 km N Guaymas: P. fraterculus. 15 km NW Guaymas: Neotoma albigula. 10 km S Hermosillo: N. albigula, P. fraterculus, Chaetodipus penicillatus. $18 \mathrm{~km} \mathrm{NE}$ Imuris: C. baileyi, C. penicillatus. $11 \mathrm{~km} \mathrm{S,} 3 \mathrm{~km}$ W Naco: $N$. albigula, P. boylii (Loomis 1971). Specimens in collections: FMNH, USNM.

Euschoengastoides opimus Loomis, 1971

BAJA CALIFORNIA: 10 km S Puertecitos: Chaetodipus formosus (Loomis 1971). Specimens in collections: USNM.

\section{Euschongastoides ryckmani (Brennan, 1966)}

SONORA: Isla Tiburón, Cholla Valley: Chaetodipus sp. (Brennan 1966). Unknown if specimens are in collections. 15 km NW Guaymas: C. penicillatus (Loomis 1971). Specimens in collections: USNM.

\section{Euschoengastoides tanigoshii Loomis, 1971}

SONORA: 21 km E Carbo: Chaetodipus baileyi. El Novillo: Peromyscus fraterculus. $18 \mathrm{~km}$ NE Imuris: P. boylii, C. penicillatus. 8 km S Naco: P. boylii. 11 km S, 3 km W Naco: C. intermedius, C. penicillatus (Loomis 1971). Specimens in collections: OSAL, USNM.

\section{Euschoengastoides tumidus Loomis, 1971}

CHIHUAHUA: 15 km WSW San Buenaventura: Neotoma albigula (Loomis 1971). Specimens in collections: USNM. DURANGO: 72-96 km N Casco: Dipodomys ordii (Loomis 1971). Specimens in collections: USNM. ESTADO DE MÉXICO: 6 km E, 3 km S Amecameca: Peromyscus melanotis (Loomis 1971). Specimens in collections: USNM. NAYARIT: 7-9 km E San Blas; 14 km E San Blas; 11 km E Ixtlán del Río: Heteromys pictus (Loomis 1971). Specimens in collections: USNM. SINALOA: 22 km N Culiacán: Chaetodipus artus, C. pernix, Heteromys pictus. $25 \mathrm{~km}$ E Culiacancito; $25 \mathrm{~km} \mathrm{~N}$ Mazatlán: C. pernix. Río Piaxtla, 88 km N Mazatlán: Onychomys torridus, Peromyscus fraterculus, C. artus, C. pernix. 27 km NW San Blas: C. goldmani (Loomis 1971). Specimens in collections: USNM. SONORA: 13 km NW Cananea: Peromyscus boylii. El Novillo: P. fraterculus. 18 km NE Imuris: Chaetodipus penicillatus. 11 km S, 3 km N Álamos; 13 km W Álamos:
Neotoma albigula. 16 km E Álamos: C. pernix. 13 km SSE Álamos: N. albigula, Peromyscus fraterculus, C. artus, C. pernix (Loomis 1971). Specimens in collections: OSAL, USNM.

\section{Euschoengastoides wadei Loomis, 1969}

CAMPECHE: 7.5 km W Escárcega: Ototylomys phyllotis (Loomis 1969). Specimens in collections: OSAL, SEMC. YUCATÁN: 2 km N Pisté: Ototylomys phyllotis (Loomis 1969). Specimens in collections: SEMC.

\section{Euschoengastoides webbi Loomis, 1971}

BAJA CALIFORNIA: 1 km NW Arrastras: Peromyscus fraterculus, Chaetodipus fallax, Dipodomys merriami. $8 \mathrm{~km} \mathrm{~N}$ San Felípe: C. spinatus (Loomis 1971). Specimens in collections: OSAL, USNM. Note: P. eremicus was recognized as the original host. However, P. eremicus from the northern part of the Baja California peninsula is now recognized as $P$. fraterculus (Álvarez-Castañeda et al. 2010). BAJA CALIFORNIA SUR: 27 km W Santa Rosalía: Chaetodipus rudinoris (Loomis 1971). Specimens in collections: USNM. Note: Chaetodipus baileyi was recognized as the original host. However, according to Riddle et al. (2000), C. baileyi from the Baja California peninsula are now recognized as $C$. rudinoris.

\section{Euschoengastoides sp.}

JALISCO: Chamela Biological Station: Heteromys pictus (Gómez-Rodríguez et al. 2015). Specimens in collections: CNAC.

Eutrombicula alfreddugesi (Oudemans, 1910)

CAMPECHE: 7.5 km W Escárcega: Handleyomys melanotis (recorded as Orzyomys melanotis), Ototylomys phyllotis, Sigmodon hispidus. 103 km SE Escárcega: S. hispidus (Loomis 1969). Specimens in collections: FMNH. Note: H. melanotis and S. hispidus are not distributed in Campeche according to Ceballos (2014). A possible alternative host includes $S$. toltecus (Ceballos 2014). CHIAPAS: Carretera Panamericana; Río San Gregorio; Neotoma mexicana (Hoffmann 1990). Specimens in collections: Unknown; Hoffmann collection is in the CNAC. CHIHUAHUA: Barranca del Río Guachochic: Peromyscus maniculatus (Hoffmann 1990). Specimens in collections: Unknown; Hoffmann collection is in the CNAC. MICHOACÁN: 3 km N Pátzcuaro: Sigmodon hispidus (Hoffmann 1990). Specimens in collections: Unknown; Hoffmann collection is in the CNAC. Note: S. hispidus is not distributed in Michoacán according to Ceballos (2014). Possible alternative hosts include $S$. alleni, S fulviventer, or S. mascotensis (Ceballos 2014). OAXACA: 12 km NE Oaxaca: Reithrodontomys fulvescens (Hoffmann 1990). Specimens in collections: Unknown; Hoffmann collection is in the CNAC. QUINTANA ROO: 4 km NNE Felipe Carrillo Puerto: Handleyomys melanotis (recorded as Oryzomys melanotis), Ototylomys phyllotis. Pueblo Nuevo X-Can: Ototylomys phyllotis (Loomis 1969). Specimens in collections: FMNH. Note: $H$. melanotis is not distributed in Quintana Roo according to 
Ceballos (2014). SAN LUIS POTOSÍ: Región de Bocas: Neotoma micropus (Hoffmann 1990). Specimens in collections: Unknown; Hoffmann collection is in the CNAC. VERACRUZ: $18 \mathrm{~km}$ NW Teocelo, Mpio. Ixhuacán: Microtus quasiater (Estébanes-González and Cervantes 2005). Specimens in collections: IBUNAM. YUCATÁN: Chichén Itzá: Otonyctomys hatti. 2 km E Chichén Itzá: Handleyomys melanotis (recorded as Oryzomys melanotis). Pisté: Peromyscus melanotis (Loomis 1969). Specimens in collections: FMNH. Note: H. melanotis and P. melanotis are not distributed in Yucatán according to Ceballos (2014).

Eutrombicula batatas (Linnaeus, 1758)

GUERRERO: Orzyomys couesi (OSAL). Specimens in collections: OSAL. OAXACA: 12 km NE Oaxaca: Oryzomys palustris (Hoffmann 1990). Specimens in collections: Unknown; Hoffmann collection is in the CNAC. Note: $O$. palustris is not distributed in Oaxaca according to Ceballos (2014). TAMAULIPAS: Orzyomys sp. (OSAL). Specimens in collections: OSAL. VERACRUZ: Tres Valles: Sigmodon sp. (Estébanes-González and Cervantes 2005). Specimens in collections: IBUNAM. YUCATÁN: 3 km N Pisté: Sigmodon hispidus (Loomis 1969). Specimens in collections: FMNH. Note: S. hispidus is not distributed in Yucatán according to Ceballos (2014). A possible alternative host includes $S$. toltecus (Ceballos 2014).

Hexidionis (Hexidionis) allredi (Brennan and Beck, 1956)

BAJA CALIFORNIA: Las Arrastras: Neotoma bryanti. Isla Tiburón: Dipodomys sp. (Brennan 1966). Unknown if specimens are in collections. Neotoma bryanti (OSAL). Specimens in collections: OSAL. Note: Neotoma lepida was recognized as the original host. However, all Neotoma from the Baja California peninsula are now recognized as N. bryanti (Patton et al. 2007). SONORA: 6 km N Navojoa: Neotoma albigula. $13 \mathrm{~km}$ SSE Álamos: N. albigula, Onychomys torridus, Peromyscus fraterculus, Chaetodipus artus, C. goldmani. $10 \mathrm{~km}$ S Hermosillo: N. albigula, P. fraterculus. $3 \mathrm{~km} \mathrm{~S}$ El Novillo: C. goldmani (Lucas and Loomis 1968). Specimens in collections: FMNH.

Hexidionis (Hexidionis) jessiemae (Gould, 1956)

BAJA CALIFORNIA: Las Arrastras; Isla Tiburón: Chaetodipus sp. (Brennan 1966). Specimens in collection: Unknown, possibly USNM.

Hexidionis (Hexidionis) macropus Loomis and Lucas, 1970

BAJA CALIFORNIA SUR: La Burrera: Peromyscus eva (Loomis and Lucas 1970). Specimens in collections: OSAL. Note: $P$. eremicus was recognized as the original host. However, P. eremicus from the southern part of the Baja California peninsula is now recognized as P. eva (ÁlvarezCastañeda et al. 2010).
Hexidionis (Hexidionis) navojoae Lucas and Loomis, 1968

SONORA: 6 km N Navojoa: Neotoma albigula, Chaetodipus pernix. 13 km SSE Álamos; 3 km S El Novillo: Peromyscus fraterculus. 8 km W La Estrella: C. baileyi. $10 \mathrm{~km}$ S Hermosillo: P. fraterculus, C. penicillatus (Lucas and Loomis 1968). Specimens in collections: FMNH, OSAL, USNM.

Hexidionis (Zosteridionis) breviseta (Loomis and Crossley, 1963)

NUEVO LEÓN: 8 km N, 5 km W La Gloria: Perognathus merriami (Loomis and Crossley 1963). Specimens in collections: SMEC.

Hexidionis (Zosteridionis) deserti Loomis and Lucas, 1970

BAJA CALIFORNIA: 18 km de San Felipe: Dipodomys merriami (Loomis and Lucas 1970). Unknown if specimens are in collections. SONORA: 34 km SE San Luis:Dipodomys merriami. $6 \mathrm{~km} N$ Puerto Peñasco; $2.5 \mathrm{~km}$ SE San Luis: D. deserti (Loomis and Lucas 1970). Unknown if specimens are in collections.

Hexidionis (Zosteridionis) doremi (Brennan and Beck, 1956)

SONORA: Known hosts are heteromyid rodents (Lucas and Loomis 1968). Specimens in collections: FMNH.

Hexidionis (Zosteridionis) harveyi Loomis and Lucas, 1970

SONORA: 15.3 km SW Agua Prieta: Dipodomys merriami. Specimens in collections: OSAL.

Hexidionis (Zosteridionis) polytechnica (Hoffmann, 1963)

ESTADO DE MÉXICO: Ojotongo; Lagunas de Zempoala: Reithrodontomys sp. (Hoffmann 1963). Specimens in collections: Unknown; Hoffmann collection is in the CNAC.

\section{Hoffmannina haramotoi Brennan and Goff, 1977}

OAXACA: $1 \mathrm{~km}$ N of Esperanza, Mpio. Santiago Comaltepec, distrito Ixtlán; $8 \mathrm{~km} \mathrm{~S}$ of Esperanza, Mpio. Santiago Comaltepec: Handleyomys alfaroi (recorded as Oryzomys alfaroi). $11 \mathrm{~km} \mathrm{SW}$ of Esperanza to San Isidro, Mpio. Santiago Comaltepec: $H$. alfaroi (recorded as O. alfaroi), Microtus mexicanus, M. oaxacensis, Megadontomys cryophilus, Peromyscus melanocarpus, Reithrodontomys mexicanus, Heteromys desmarestianus. Llano de las Flores, Km 132, Tuxtepec, Mpio. Atepec: M. mexicanus (Estébanes-González and Cervantes 2005). Specimens in collections: IBUNAM.

\section{Hoffmannina suriana (Hoffmann, 1954)}

CAMPECHE: 7.5 km W Escárcega: Peromyscus leucopus, P. yucatanicus (Loomis 1969). Specimens in collections: FMNH. CHIAPAS: Cerro del Cañón del Sumidero; 19 km NW Tuxtla Gutiérrez: Peromyscus mexicanus (Hoffmann 1954). Specimens in collections: Unknown; Hoffmann collection is 
in the CNAC. MORELOS: Volcán Popocatépetl, 1 km SW San Pedro Atlixco: Peromyscus difficilis (Hoffmann 1990). Specimens in collections: Unknown; Hoffmann collection is in the CNAC. OAXACA: 3 km SW Totontepc, Mpio. Totontepec: Peromyscus melanocarpus. Cerro Zempoaltépetl, $5 \mathrm{~km} \mathrm{~N}$ Santa María Yacochi, Mpio. Tlahuitoltepec: Microtus umbrosus (Estébanes-González and Cervantes 2005). Specimens in collections: IBUNAM.

Hyponeocula arenicola (Loomis, 1954)

BAJA CALIFORNIA: 16 km S Paso de San Matías; 12 km S, 42 km E San Vicente; Valle Trinidad; 77 km SE Ensenada: Dipodomys simulans (Tanigoshi and Loomis 1974). Specimens in collections: FMNH, SMEC. Note: Dipodomys agilis was recognized as the original host. However, all D. agilis from the Baja California peninsula are now recognized as $D$. simulans (Sullivan and Best 1997; Patton and Álvarez-Castaneda 1999). COAHUILA: 18 km N Tanque Álvarez: Dipodomys nelsoni (Tanigoshi and Loomis 1974). Specimens in collections: FMNH, SMEC. DURANGO: 29 km SSW Tepehuanes: Sigmodon leucotis (Tanigoshi and Loomis 1974). Specimens in collections: FMNH, SMEC. SONORA: $15 \mathrm{~km}$ WSW Agua Prieta: Chaetodipus intermedius, C. penicillatus, Dipodomys merriami. 8 km S Naco: D. merriami (Tanigoshi and Loomis 1974). Specimens in collections: FMNH, SMEC.

Hyponeocula deserticola Tanigoshi and Loomis, 1974

SONORA: 3 km S El Novillo: Chaetodipus goldmani. A lo largo del Río Yaqui: Known rodent hosts are heteromyid rodents (Tanigoshi and Loomis 1974). Specimens in collections: FMNH.

Hyponeocula imitator Tanigoshi and Loomis, 1974

BAJA CALIFORNIA: 11 km N San Felipe: Dipodomys merriami (Tanigoshi and Loomis 1974). Specimens in collections: FMNH. SONORA: 8 km N Guaymas: Chaetodipus penicillatus, Dipodomys merriami. 14 km NW Guaymas (Bahía de San Carlos): D. merriami (Tanigoshi and Loomis 1974). Specimens in collections: FMNH.

Hyponeocula luciae Tanigoshi and Loomis, 1974

SINALOA: 2 km NE Santa Lucía: Peromyscus boylii (Tanigoshi and Loomis 1974). Specimens in collections: FMNH. Note: $P$. boylii is not distributed in Sinaloa according to Ceballos (2014).

Hyponeocula rugosa Tanigoshi and Loomis, 1974

SINALOA: 25 km N, 2 km E Culiacán: Chaetodipus artus. 18 km S Guamúchil: C. pernix (Tanigoshi and Loomis 1974). Specimens in collections: FMNH. SONORA: 2 km SSE Álamos: Chaetodipus goldmani. 8 km W Álamos (La Aduana): C. pernix. 13 km W Álamos en Agua Marín: C. artus, C. goldmani. $2 \mathrm{~km}$ W Tajitos: C. penicillatus (Tanigoshi and Loomis 1974). Specimens in collections: FMNH, OSAL.
Leptotrombidium panamensis (Ewing, 1925)

BAJA CALIFORNIA: Las Arrastras: Neotoma bryanti (Brennan 1966). Unknown if specimens are in collections. Note: Neotoma lepida was recognized as the original host. However, all Neotoma from the Baja California peninsula are now recognized as N. bryanti (Patton et al. 2007). CAMPECHE: 5 km S Champotón: Ototylomys phyllotis, Heteromys gaumeri. $7.5 \mathrm{~km}$ W Escárcega; 103 km SE Escárcega: Sigmodon hispidus. 65 km S, 128 km W Escárcega: O. phyllotis (Loomis 1969). Specimens in collections: FMNH. Note: S. hispidus is not distributed in Campeche according to Ceballos (2014). A possible alternative host includes S. toltecus (Ceballos 2014). CHIAPAS: 17 km NW Teopisca, camino a San Cristóbal Las Casas: Peromyscus boylii. Río San Gregorio at Carretera Panamericana: Neotoma mexicana, P. mexicanus, Heteromys pictus (Hoffmann 1990). Specimens in collections: Unknown; Hoffmann collection is in the CNAC. Note: P. boylii is not distributed in Chiapas according to Ceballos (2014). MICHOACÁN: Chorros del Varal: Osgoodomys banderanus (Estébanes-González and Cervantes 2005). Specimens in collections: IBUNAM. QUINTANA ROO: 4 km NNE Felípe Carrillo Puerto: Ototylomys phyllotis, Heteromys gaumeri (Loomis 1969). Specimens in collections: FMNH. OAXACA: Monte Albán: Baiomys musculus. Tehuantepec: Peromyscus mexicanus (Hoffmann 1990). Specimens in collections: Unknown; Hoffmann collection is in the CNAC. SONORA: $25 \mathrm{~km} \mathrm{SW}$ Navojoa: Chaetodipus pernix (Ryckman and Roos 1955). Unknown if specimens are in collections. YUCATÁN: $2 \mathrm{~km}$ E Chichén Itzá: Ototylomys phyllotis (Loomis 1969). Specimens in collections: FMNH.

Leptotrombidium potosina (Hoffmann, 1950)

CIUDAD DE MÉXICO: Pedregal de San Angel: Peromyscus gratus (recording as P. truei; Hoffmann 1990). Specimens in collections: Unknown; Hoffmann collection is in the CNAC. MICHOACÁN: 9 km NW Zamora: Reithrodontomys fulvescens. $10 \mathrm{~km}$ E Zamora: Heteromys irroratus (Hoffmann 1990). Specimens in collections: Unknown; Hoffmann collection is in the CNAC. PUEBLA: Volcán Popocatépetl, 1 km SW San Pedro Atlixco: Peromyscus difficilis (Hoffmann 1990). Specimens in collections: Unknown; Hoffmann collection is in the CNAC. SAN LUIS POTOSÍ: Región de Bocas: Neotoma micropus (Hoffmann 1950). El Salto: Oryzomys palustris (Hoffmann 1990). Specimens in collections: Unknown; Hoffmann collection is in the CNAC. San Luis Potosí: N. micropus (OSAL). Specimens in collections: OSAL. Note: O. palustris is not distributed in San Luis Potosí according to Ceballos (2014).

Microtrombicula aequalis Webb Jr. and Loomis, 1971

SONORA: 8 km W of El Novillo: Peromyscus boylii (Webb and Loomis 1971). Specimens in collections: USNM. 
Microtrombicula fisheri Webb Jr. and Loomis, 1971

BAJA CALIFORNIA SUR: La Laguna: Peromyscus truei (Webb and Loomis 1971). Specimens in collections: USNM.

Microtrombicula intermedia Webb Jr. and Loomis, 1971

SONORA: 13 km S-SE of Álamos: Peromyscus fraterculus (Webb and Loomis 1971). Specimens in collections: USNM.

Neotrombicula azteca (Hoffmann, 1952)

CIUDAD DE MÉXICO: La Venta: Peromyscus hylocetes (Hoffmann 1952). El Zarco: Microtus mexicanus (Hoffmann 1990). Specimens in collections: Unknown; Hoffmann collection is in the CNAC. ESTADO DE MÉXICO: La Cachucha, Lagunas de Zempoala: Peromyscus maniculatus. La Piedad, Lagunas de Zempoala: Microtus sp. Volcán Popocatépetl, 5 km E San Pedro Nexapa: Reithrodontomys sp. (Hoffmann 1990). Specimens in collections: Unknown; Hoffmann collection is in the CNAC.

\section{Neotrombicula bakeri (Ewing, 1946)}

MICHOACÁN: 12 km NE Pátzcuaro; 10 km E Zamora: Heteromys irroratus (Hoffmann 1990). Specimens in collections: Unknown; Hoffmann collection is in the CNAC.

\section{Neotrombicula caballeroi (Hoffmann, 1960)}

CHIAPAS: Camino a San Cristóbal; 17 km NW Teopisca; San Cristóbal Las Casas: Neotoma mexicana, Peromyscus boylii (Hoffmann 1960a). Carretera Panamericana at Río San Gregorio: P. mexicanus (Hoffmann 1990). Specimens in collections: Unknown; Hoffmann collection is in the CNAC. Note: $P$. boylii is not distributed in Chiapas according to Ceballos (2014). DURANGO: La Michilía: Peromyscus difficilis (Hoffmann 1990). Specimens in collections: Unknown; Hoffmann collection is in the CNAC. ESTADO DE MÉXICO: Ojotongo, Lagunas de Zempoala: Microtus sp. Paraje Otlaltepec del volcán Popocatépetl: Peromyscus melanotis. Volcán Popocatépetl: Reithrodontomys fulvescens (Hoffmann 1990). Specimens in collections: Unknown; Hoffmann collection is in the CNAC.

\section{Neotrombicula claudioi (Hoffmann, 1965)}

ESTADO DE MÉXICO: Mirador del Poeta, Volcán Popocatépetl: Neotomodon alstoni (Hoffmann 1965). Specimens in collections: Unknown; Hoffmann collection is in the CNAC. OAXACA: 1 km N Esperanza, Mpio. Santiago Comaltepec, Distrito Ixtlán: Handleyomys alfaroi (recorded as Oryzomys alfaroi). 8 km S Esperanza, Santiago Comaltepec; Cerro Zempoaltépetl, 4 km E Yacochi, Mpio. Tlahuitoltepec: Peromyscus melanocarpus. $11 \mathrm{~km} \mathrm{SW}$ Esperanza to San Isidro, Mpio. Santiago Comaltepec: Megadontomys cryophilus, Microtus oaxacensis, P. melanocarpus, Reithrodontomys mexicanus, Heteromys desmarestianus. 3 km SE Totontepec, Mpio. Totontepec: Megadontomys cryophilus, P. melanocarpus, $R$. mexicanus, $H$. desmarestianus. Llano de las Flores, Km 132 Tuxtepec, Mpio. Atepec: Microtus mexicanus. Cerro Zempoaltépetl, 4.5 km N Santa María Yachochi, Mpio. Tlahuitoltepec: Habromys lepturus (Estébanes-González and Cervantes 2005). Specimens in collections: IBUNAM. VERACRUZ: 5 km W Naolinco, Mpio. Naolinco: Microtus quasiater, Peromyscus levipes. Banderilla, 6 km NW Xalapa: M. quasiater (Estébanes-González and Cervantes 2005). Specimens in collections: IBUNAM.

\section{Neotrombicula microti (Ewing, 1928)}

ESTADO DE MÉXICO: La Piedra cerca de Ojotongo, Lagunas de Zempoala: Microtus sp. Volcán Popocatépetl, el Paraje Diego de Ordaz: M. mexicanus (Hoffmann 1990). Specimens in collections: Unknown; Hoffmann collection is in the CNAC.

Neotrombicula universitatis (Hoffmann, 1963)

SAN LUIS POTOSÍ: El Salto: Heteromys sp. (Hoffmann 1963). Specimens in collections: Unknown; Hoffmann collection is in the CNAC.

Otorhinophila baccusi Loomis and Wrenn, 1973

COAHUILA: 27 km E Cuatro Ciénegas: Chaetodipus hispidus (Loomis and Wrenn 1973). Specimens in collections: FMNH, USNM. Note: Although C. hispidus to known to occur in Coahuila, it may not occur as far south as Cuatro Ciénegas. Other possible hosts include C. eremicus or C. nelsoni.

Otorhinophila desertorum Loomis and Wrenn, 1973

SONORA: 88 km SE San Luis: Dipodomys merriami (Loomis and Wrenn 1973). Specimens in collections: FMNH, USNM.

Otorhinophila intrasola Wrenn and Loomis, 1967

SINALOA: 3.5 km SW San Blas; 1.3 km NE El Fuerte: Chaetodipus pernix. $10.5 \mathrm{~km}$ NW San Blas: C. artus (Wrenn and Loomis 1967). Specimens in collections: FMNH, USNM. SONORA: 5 km SSE Álamos, Río Cuchujaqui: Peromyscus fraterculus, Chaetodipus artus, C. pernix, Heteromys pictus. 2 km SSE Álamos; 9 km W Álamos; 9 km E Navojoa; 6 km ENE Navojoa (Tierra Blanca): C. goldmani. La Aduana, $2.5 \mathrm{~km} \mathrm{~N}$ Navojoa; Cerca de la presa El Novillo a 50 km E, 4 km S Hermosillo: C. goldmani, C. pernix. 9 km W Minas Nuevas; 6 km E Navojoa: C. pernix. 6 km NW Guaymas (Bahía de San Carlos); 3.5 km S Hermosillo: C. penicillatus. 8 km E Carbo: C. baileyi. 300m W Tajitos: C. intermedius (Wrenn and Loomis 1967). Specimens in collections: FMNH, USNM.

\section{Otorhinophila parvisola Wrenn and Loomis, 1967}

BAJA CALIFORNIA: Las Arrastras: Neotoma bryanti. 3.5 km S Puertecitos: Chaetodipus formosus. Puertecitos: N. bryanti, C. formosus, C. penicillatus. $3 \mathrm{~km} \mathrm{~N}$ Puertecitos: C. formosus, C. penicillatus (Wrenn and Loomis 1967). Specimens in collections: FMNH, USNM. Note: Neotoma lepida was rec- 
ognized as the original host. However, all Neotoma from the Baja California peninsula are now recognized as $N$. bryanti (Patton et al. 2007). SONORA: 6 km NW Guaymas (cerca de Bahía de San Carlos): Neotoma albigula, Onychomys torridus, Chaetodipus penicillatus, Dipodomys merriami. 2 km N Guaymas: C. baileyi, C. intermedius. 6.5 km NW Guaymas: C. penicillatus. Kino Nuevo en Bahía Kino; 5 km de Puerto Peñasco; Isla Tiburón: N. albigula. 600 m SE Puerto Peñasco: N. lepida (Wrenn and Loomis 1967). Specimens in collections: FMNH, USNM. Note: N. albigula is the incorrect host and/or that $N$. devia may also be a host from this particular locality.

Otorhinophila sinaloae Wrenn and Loomis, 1967

SINALOA: 34 km N Mazatlán (Río Piaxtla): Chaetodipus pernix. 8.5 km NW Culiacán: Heteromys pictus. 5 km NW, 300 m N Guamúchil: C. artus (Wrenn and Loomis 1967). Specimens in collections: FMNH, USNM.

Otorhinophila sola (Gould, 1956)

BAJA CALIFORNIA: 300 m N Puertecitos: Neotoma bryanti, Chaetodipus penicillatus (Wrenn and Loomis 1967). 10 km S Puertecitos: C. formosus (Loomis and Wrenn 1973). Specimens in collections: FMNH, USNM. Note: Neotoma lepida was recognized as the original host. However, all Neotoma from the Baja California peninsula are now recognized as N. bryanti (Patton et al. 2007).

Otorhinophila xerophila Loomis and Wrenn, 1973

BAJA CALIFORNIA: Misión de Calamajué: Neotoma bryanti (Loomis and Wrenn 1973). Specimens in collections: FMNH, USNM. Note: Neotoma lepida was recognized as the original host. However, all Neotoma from the Baja California peninsula are now recognized as $N$. bryanti (Patton et al. 2007).

Parasecia gurneyi (Ewing, 1937)

CAMPECHE: 5 km SChampotón: Ototylomys phyllotis. 7.5 km W Escárcega: Peromyscus leucopus, Heteromys gaumeri (Loomis 1969). Specimens in collections: FMNH. YUCATÁN: Chichén Itzá: Peromyscus yucatanicus. 3 km N Pisté: P. leucopus (Loomis 1969). Specimens in collections: FMNH.

Speleocola secunda Brennan and Jones, 1969 CAMPECHE: 7 km N, 51 km E Escárcega: Peromyscus yucatanicus (Loomis and Webb 1969). Specimens in collections: FMNH. YUCATÁN: 6 km S Mérida; 3 km N Pisté: Peromyscus yucatanicus (Loomis and Webb 1969). Specimens in collections: $\mathrm{FMNH}$.

Schoengastiinae Vercammen-Grandjean, 1960

Cordiseta aberrans (Brennan and Jones, 1959)

CHIAPAS: 6 km NW Teopisca: Peromyscus oaxacensis
(Brennan and Jones 1959). Specimens in collections: USNM. Carretera Panamericana at Río San Gregorio: Neotoma mexicana, P. mexicanus. Cerro del Cañón del Sumidero, 11 km NW Tuxtla Gutiérrez: Heteromys pictus (Hoffmann 1990). Specimens in collections: Unknown; Hoffmann collection is in the CNAC. MICHOACÁN: 12 km NE Pátzcuaro: Heteromys irroratus (Hoffmann 1990). Specimens in collections: Unknown; Hoffmann collection is in the CNAC.

\section{Cordiseta hoffmanae (Brennan, 1960)}

CHIAPAS: Tuxtla Gutiérrez: Baiomys musculus (Brennan 1960a). Specimens in collections: USNM. JALISCO: Chamela Biological Station: Heteromys pictus (Gómez-Rodríquez et al. 2015). Specimens in collections: CNAC. MICHOACÁN; Heteromys sp. (Brennan 1960a). Specimens in collections: USNM. OAXACA: Monte Albán: Baiomys musculus (Hoffmann 1990). Specimens in collections: Unknown; Hoffmann collection is in the CNAC.

\section{Cordiseta mexicana (Hoffmann, 1954)}

CAMPECHE: 5 km S Champotón; 7.6 km W Escárcega: Heteromys gaumeri (Loomis 1969). Specimens in collections: FMNH. CHIAPAS: Carretera Panamericana at Río San Gregorio: Neotoma mexicana (Hoffmann 1954). Specimens in collections: Unknown; Hoffmann collection is in the CNAC. QUINTANA ROO: Pueblo Nuevo X-Cán: Peromyscus yucatanicus (Loomis 1969). Specimens in collections: FMNH.

\section{Dermadelema furmani (Gould, 1956)}

BAJA CALIFORNIA: 1 km N Puertecitos; 19 km NE Rancho Laguna Chapala: Neotoma bryanti (Pomeroy and Loomis 1984). Specimens in collections: FMNH. SONORA: 4 km NW El Desemboque: Neotoma albigula, Peromyscus fraterculus. 25 km N Guaymas: P. fraterculus. 30 km SW Pitiquito: N. albigula. 88 km SE San Luis: Dipodomys merriami (Pomeroy and Loomis 1984). Specimens in collections: FMNH. Note: Neotoma lepida was recognized as the original host. However, all Neotoma from the Baja California peninsula are now recognized as N. bryanti (Patton et al. 2007).

Dermadelema sleeperi Pomeroy and Loomis, 1984

BAJA CALIFORNIA: $3 \mathrm{~km}$ N Puertecitos: Chaetodipus formosus. 8 km N San Felipe: Dipodomys merriami (Pomeroy and Loomis 1984). Specimens in collections: FMNH. SINALOA: 1 km NE Santa Lucía: Peromyscus boylii (OSAL). Specimens in collections: OSAL. Note: $P$. boylii is not distributed in Sinaloa according to Ceballos (2014). SONORA: 88 km SE San Luis: Dipodomys merriami (Pomeroy and Loomis 1984). Specimens in collections: FMNH.

\section{Ectonyx fusicornis Brennan, 1960}

JALISCO: Chamela Biological Station: Heteromys pictus 
(Gómez-Rodríguez et al. 2015). Specimens in collections: CNAC. PUEBLA: Heteromys irroratus (Brennan 1960b). Specimens in collections: OSAL, USNM. YUCATÁN: $3 \mathrm{~km} \mathrm{~N}$ Pisté: Heteromys gaumeri (Loomis 1969). Specimens in collections: FMNH.

\section{Euschoengastia ambocalis Wrenn and Loomis, 1973}

BAJA CALIFORNIA: 5 km S El Rayo: Peromyscus truei. 2.5 km S El Topo: P. truei, Chaetodipus californicus, Dipodomys simulans. La Rumorosa: P. fraterculus. (Loomis and Somerby 1966). Specimens in collections: FMNH. Note: P. fraterculus are not distributed in Baja California according to Ceballos (2014). Peromyscus eremicus was recognized as the original host. However, P. eremicus from the northern part of the Baja California peninsula is now recognized as $P$. fraterculus (Álvarez-Castañeda et al. 2010). Dipodomys agilis was recognized as the original host. However, all $D$. agilis from the Baja California peninsula are now recognized as $D$. simulans (Sullivan and Best 1997; Patton and Álvarez-Castaneda 1999).

\section{Euschoengastia ampliseta Loomis and Somerby, 1966}

DURANGO: $60 \mathrm{~m}$ W Buenos Aires (22 km W El Salto): Peromyscus boylii, P. melanotis. $600 \mathrm{~m}$ W El Salto: P. melanotis (Loomis and Somerby 1966). Specimens in collections: FMNH. JALISCO: No data. Known hosts are mainly small rodents, likely cricetid and heteromyid rodents. (Wrenn 1987). Unknown if specimens are in collections.

\section{Euschoengastia barrerai Hoffmann, 1960}

CHIHUAHUA: Barranca del Río Guachochic: Peromyscus maniculatus (Hoffmann 1990). Specimens in collections: Unknown; Hoffmann collection is in the CNAC. CIUDAD DE MÉXICO: La Venta: Peromyscus hylocetes (Hoffmann 1990). Specimens in collections: Unknown; Hoffmann collection is in the CNAC. DURANGO: $600 \mathrm{~m}$ W Buenos Aires; 20 km W El Salto: Peromyscus melanotis. (Loomis and Somerby 1966). Specimens in collections: FMNH. La Michilía: P. difficilis (Hoffmann 1990). Specimens in collections: Unknown; Hoffmann collection is in the CNAC. ESTADO DE MÉXICO: 250 m W Paso de Cortés; Popocatépetl: Peromyscus maniculatus (Hoffmann 1960b; Whitaker et al. 1991). Specimens in collections: Unknown; Hoffmann collection is in the CNAC. Ojotongo, Lagunas de Zempoala: Microtus sp., Neotoma sp., Peromyscus maniculatus. La Piedra, Lagunas de Zempoala: Microtus sp., Reithrodontomys sp. La Cachucha, Lagunas de Zempoala: P. maniculatus. Nevado de Toluca: Reithrodontomys sp. Mirador del Poeta, Volcán Popocatépetl: M. mexicanus, Neotomodon alstoni (Hoffmann 1990). Specimens in collections: Unknown; Hoffmann collection is in the CNAC. NUEVO LÉON: Cerro Potosí 18 km N Galeana: Peromyscus maniculatus (Hoffmann 1990). Specimens in collections: Unknown; Hoffmann collection is in the CNAC. PUEBLA: $10 \mathrm{~km}$ W San Martín Texmelucan, Mpio. San Martín Texmelucan: Pero- myscus maniculatus (Estébanes-González and Cervantes 2005). Specimens in collections: IBUNAM. $2 \mathrm{~km}$ W Atenco de Aljojuca: Dipodomys phillipsi (Hoffmann 1990). Specimens in collections: Unknown; Hoffmann collection is in the CNAC. Note:Wrenn (1987) also notes this species from Veracruz and Nuevo Léon. Additional hosts for this species include Neotoma albigula, Neotomodon alstoni, Neotoma sp., P. melanotis, and Peromyscus sp. (Whitaker et al. 1991). Although Whitaker et al. (1991) state than an additional host from Veracruz and Nuevo Léon may be N. albigula, this species does not occur in these states (Ceballos 2014). SONORA: 5 km SSE Álamos, Río Cuchujaqui: Peromyscus fraterculus (Loomis and Somerby 1966). Specimens in collections: FMNH.

\section{Euschoengastia criceticola Brennan, 1948}

BAJA CALIFORNIA: $5.5 \mathrm{~km}$ S El Rayo: Peromyscus truei. 2.5 km S El Topo: Neotoma macrotis, N. bryanti, P. truei, Chaetodipus californicus, Dipodomys simulans. La Rumorosa: $P$. fraterculus, P. maniculatus, C. fallax. $5 \mathrm{~km}$ SW La Rumorosa; Sierra San Pedro Mártir; El Socorro; 6 km E José del Castillo: D. simulans, $9 \mathrm{~km}$ W Santo Tomás, P. californicus (Loomis and Somerby 1966). Specimens in collections: FMNH. Note: N. fusipes from Baja California is now recognized as N. macrotis (Matoca 2002). Neotoma lepida was recognized as the original host. However, all Neotoma from the Baja California peninsula are now recognized as N. bryanti (Patton et al. 2007). Dipodomys agilis was recognized as the original host. However, all D. agilis from the Baja California peninsula are now recognized as $D$. simulans (Sullivan and Best 1997; Patton and Álvarez-Castaneda 1999). Peromyscus eremicus was recognized as the original host. However, P. eremicus from the northern part of the Baja California peninsula is now recognized as $P$. fraterculus (Álvarez-Castañeda et al. 2010). HIDALGO: Peromyscus difficilis (OSAL). Specimens in collections: OSAL.

\section{Euschoengastia fronterizae Wrenn et al., 1976}

COAHUILA: Sierra Fronteriza; 40 km SE Boquillas del Carmen: Peromyscus difficilis (Wrenn et al. 1976). Specimens in collections: FMNH.

\section{Euschoengastia gagarini Brennan, 1962}

GUERRERO: Heteromys irroratus (Brennan 1962). Specimens in collections: USNM.

\section{Euschoengastia heteromyicola Wrenn and Loomis, 1974}

BAJA CALIFORNIA: La Rumorosa; 5 km W, 4.4 km S La Rumorosa: Dipodomys simulans (Wrenn and Loomis 1974). Specimens in collections: FMNH, USNM. Note: Dipodomys agilis was recognized as the original host. However, all $D$. agilis from the Baja California peninsula are now recognized as D. simulans (Sullivan and Best 1997; Patton and ÁlvarezCastaneda 1999). 
Euschoengastia marginalis Wrenn and Somerby, 1974

BAJA CALIFORNIA: 2.4 km S El Topo: Neotoma macrotis, N. bryanti, Chaetodipus californicus (Wrenn and Loomis 1974). Specimens in collections: FMNH, USNM. Note: $N$. fusipes from Baja California is now recognized as N. macrotis (Matoca 2002). N. lepida was recognized as the original host. However, all Neotoma from the Baja California peninsula are now recognized as $N$. bryanti (Patton et al. 2007).

\section{Euschoengastia multisetosa Loomis and Somerby, 1966}

BAJA CALIFORNIA: 5.5 km S El Rayo: Peromyscus truei. 2.5 km S El Topo: P. truei, Chaetodipus californicus. La Rumorosa: P. fraterculus, P. maniculatus, Peromyscus sp., C. fallax (Loomis and Somerby 1966). Specimens in collections: FMNH, OSAL, USNM. Note: Peromyscus eremicus was recognized as the original host. But $P$. eremicus from the northern part of the Baja California peninsula is now recognized as $P$. fraterculus (Álvarez-Castañeda et al. 2010).

Euschoengastia numerosa Wrenn and Loomis, 1974

SONORA: 84 km SE San Luis:Dipodomys merriami (Wrenn and Loomis 1974). Specimens in collections: FMNH, USNM.

\section{Euschoengastia obscura Wrenn and Loomis, 1974}

BAJA CALIFORNIA: 6 km SW Paso de San Matías; 5 km W, 4.4 km S La Rumorosa: Dipodomys simulans (Wrenn and Loomis 1974). Specimens in collections: FMNH, USNM. Note: Dipodomys agilis was recognized as the original host. However, all D. agilis from the Baja California peninsula are now recognized as D. simulans (Sullivan and Best 1997; Patton and Álvarez-Castaneda 1999).

\section{Euschoengastia otophila Loomis and Bunnell, 1962}

BAJA CALIFORNIA: $5.5 \mathrm{~km}$ de El Rayo: Peromyscus truei (Loomis and Bunnell 1962). Specimens in collections: FMNH, USNM. SINALOA: 700 m NE Santa Lucía: Peromyscus boylii (Loomis and Bunnell 1962). Specimens in collections: FMNH, USNM. Note: $P$. boylii is not distributed in Sinaloa according to Ceballos (2014). SONORA: $4 \mathrm{~km} \mathrm{S,} 1.5 \mathrm{~km} \mathrm{~W}$ Naco: Peromyscus boylii (Loomis and Bunnell 1962). Specimens in collections: FMNH, USNM.

\section{Euschoengastia radfordi Brennan and Jones, 1962}

BAJA CALIFORNIA: La Rumorosa; 5 km W, 6 km S La Rumorosa:Dipodomys simulans (Loomis and Somerby 1966). Specimens in collections: FMNH, USNM. Note: Dipodomys agilis was recognized as the original host. However, all $D$. agilis from the Baja California peninsula are now recognized as D. simulans (Sullivan and Best 1997; Patton and ÁlvarezCastaneda 1999). DURANGO: $600 \mathrm{~m}$ W Buenos Aires; $25 \mathrm{~km}$ W El Salto: Peromyscus boylii (Loomis and Somerby 1966). Specimens in collections: FMNH, USNM. SONORA: $32 \mathrm{~km} \mathrm{SE}$
San Luis: Dipodomys merriami (Loomis and Somerby 1966). Specimens in collections: FMNH, USNM.

Euschoengastia simulans Wrenn and Loomis, 1974

DURANGO: 53 km W El Salto: Peromyscus boylii (Wrenn and Loomis 1974). Specimens in collections: FMNH, USNM.

Euschoengastia stephensi Loomis and Somerby, 1966

SONORA: 5.5 km NW Guaymas: Onychomys torridus (Loomis and Somerby 1966). Specimens in collections: FMNH, OSAL, USNM.

\section{Euschoengastia zapoteca Hoffmann, 1965}

OAXACA: Monte Albán: Baiomys musculus (Hoffmann 1965). Specimens in collections: Unknown; Hoffmann collection is in the CNAC. $1 \mathrm{~km}$ Esperanza, Mpio. Santiago Comaltpec, distrito Ixtlán: Reithrodontomys mexicanus. Llano de las Flores, Km 132 Tuxtepec, Mpio. Atepec: Peromyscus levipes. Cerro Zempoaltepetl, 5 km N Santa María Yacochi, Mpio. Tlahuitoltepec: Microtus umbrosus. Cerro Zempoaltépetl, 4.5 km N Santa María Yacochi, Mpio. Tlahuitoltepec: Microtus sp. $11 \mathrm{~km}$ SW Esperanza to San Isidro, Mpio. Santiago Comaltepec: M. mexicanus. Cerro Zempoaltepetl, 4 km E Yacochi, Mpio. Tlahuitoltepec: P. melanocarpus. $3 \mathrm{~km}$ SE Totontepec, Mpio. Totontepec: P. melanocarpus (Estébanes-González and Cervantes 2005). Specimens in collections: IBUNAM. Note: P. levipes is not distributed in Oaxaca according to Ceballos (2014). VERACRUZ: Banderillas, 6 km NW Xalapa, Mpio. Xalapa: Peromyscus furvus. 18 km NW Teocelo, Mpio. Ixhuacán: Microtus quasiater (Estébanes-González and Cervantes 2005). Specimens in collections: IBUNAM.

\section{Euschoengastia sp.}

VERACRUZ: 5 km W Noalinco, Mpio. Naolinco: Microtus quasiater (Estébanes-González and Cervantes 2005). Specimens in collections: IBUNAM.

\section{Kayella lacerta (Brennan, 1948)}

BAJA CALIFORNIA: Isla Salsipuedes: Peromyscus interparietalis. Las Arrastras: Neotoma bryanti (Brennan 1966). Specimens in collections: Unknown, possibly USNM. Note: $P$. guardia was recorded as the original host from Isla de Salsipuedes. However, P. guardia is not known to occur on this island and the most likely host is $P$. interparietalis (Ceballos 2014). Neotoma lepida was recognized as the original host. However, all Neotoma from the Baja California peninsula are now recognized as N. bryanti (Patton et al. 2007).

\section{Neoschoengastia dalmati Brennan, 1951}

COAHUILA: Reithrodontomys sp. (Brennan and Dalmat 1960). Specimens in collections: Unknown, possibly USNM. 
Parascoschoengastia nuniezi (Hoffmann, 1944)

CHIAPAS: Carretera Panamericana at Río San Gregorio: Peromyscus mexicanus (Hoffmann 1990). Specimens in collections: IBUNAM.

Pseudoschoengastia anomala (Hoffmann, 1951)

CHIAPAS: No data. Known hosts are mainly small rodents, likely cricetid and heteromyid rodents (Brennan 1960a). Specimens in collections: Unknown, possibly USNM. CIUDAD DE MÉXICO: Cerro de Zacayuca; Pedregal de San Ángel: Peromyscus gratus (recorded as P. truei; $\underline{\text { Hoff- }}$ mann 1951a). Specimens in collections: Unknown; Hoffmann collection is in the CNAC. ESTADO DE MÉXICO: Cerca de Ojotongo; Lagunas de Zempoala: Neotoma sp. (Hoffmann 1990). Specimens in collections: Unknown; Hoffmann collection is in the CNAC.

Pseudoschoengastia audyi Brennan and Jones, 1959

GUERRERO: Heteromys irroratus (Brennan and Dalmat 1960). Specimens in collections: Unknown, possibly USNM. JALISCO: Baiomys sp. (Brennan and Dalmat 1960). Specimens in collections: Unknown, possibly USNM. MICHOACÁN: Heteromys pictus (Brennan and Dalmat 1960). Specimens in collections: Unknown, possibly USNM. $12 \mathrm{~km} \mathrm{NE}$ Pátzcuaro: Heteromys irroratus. 3 km N Pátzcuaro: Sigmodon hispidus (Hoffmann 1990). Specimens in collections: Unknown; Hoffmann collection is in the CNAC. Note: S. hispidus is not distributed in Michoacán according to Ceballos (2014). Possible alternative hosts include S. alleni, S fulviventer, or S. mascotensis (Ceballos 2014). MORELOS: Oryzomys couesi (Brennan and Dalmat 1960). Specimens in collections: Unknown, possibly USNM. SAN LUIS POTOSÍ: El Salto: Oryzomys palustris (Hoffmann 1990). Specimens in collections: Unknown; Hoffmann collection is in the CNAC. Note: O. palustris is not distributed in San Luis Potosí according to Ceballos (2014). VERACRUZ: Baiomys musculus, Reithrodontomys sp. (Brennan and Dalmat 1960). Specimens in collections: Unknown, possibly USNM.

\section{Pseudoschoengastia brennani Hoffmann, 1960}

CAMPECHE: 7 km N, 51 km E Escárcega: Peromyscus yucatanicus (Loomis 1969). Specimens in collections: Unknown, possibly FMNH. CHIAPAS: 6 km NW Teopisca: Peromyscus boylii, P. oaxacensis. 7 km N, 51 km E Escárcega: P. yucatanicus. Cerro del Cañón del Sumidero, 19 km NW Tuxtla Gutiérrez; Carretera Panamericana at Río San Gregorio: P. mexicanus. (Hoffmann 1960b). Specimens in collections: Unknown; Hoffmann collection is in the CNAC. Note: $P$. boylii and $P$. yucatanicus are not distributed in Chiapas according to Ceballos (2014). QUINTANA ROO: 4 km NNE Felípe Carrillo Puerto: Handleyomys melanotis (recorded as Oryzomys melanotis), Ototylomys phyllotis. Pueblo Nuevo X-Can: Peromyscus yucatanicus (Loomis 1969). Specimens in collections: FMNH, USNM. Note: H. melanotis is not dis- tributed in Quintana Roo according to Ceballos (2014). YUCATÁN: 6 km S Mérida; 3 km N Pisté: Peromyscus yucatanicus. 66 km NE Mérida: Ototylomys phyllotis (Loomis 1969). Specimens in collections: FMNH, USNM.

Pseudoschoengastia extrinseca Brennan, 1960

CAMPECHE: 5 km S Champotón; 7 km W Escárcega: Heteromys gaumeri. $65 \mathrm{~km} \mathrm{~S}, 128$ km E Escárcega: Ototylomys phyllotis (Loomis 1969). Specimens in collections: Unknown, possibly FMNH. QUINTANA ROO: 4 km NNE Felipe Carrillo Puerto: Ototylomys phyllotis, Heteromys gaumeri (Loomis 1969). Specimens in collections: Unknown, possibly FMNH. YUCATÁN: 2 km E Chichén Itzá: Ototylomys phyllotis. Pisté: O. phyllotis, Heteromys gaumeri (Loomis 1969). Specimens in collections: Unknown, possibly FMNH. VERACRUZ: Peromyscus mexicanus (OSAL). Specimens in collections: OSAL.

Pseudoschoengastia guatemalensis Brennan, 1952

CHIAPAS: Cerro Tzontehuitz, 13 km NE San Cristóbal de las Casas, Mpio. San Juan Chamula: Reithrodontomys microdon (Estébanes-González and Cervantes 2005). Specimens in collections: IBUNAM. COAHUILA: Neotoma sp., Peromyscus sp. (Brennan and Dalmat 1960). Specimens in collections: Unknown, possibly USNM. ESTADO DE MÉXICO: Ojotango, Lagunas de Zempoala: Peromyscus maniculatus (Hoffmann 1990). Specimens in collections: Unknown; Hoffmann collection is in the CNAC. MICHOACÁN: Heteromys pictus (Brennan and Dalmat 1960). Specimens in collections: Unknown, possibly USNM. MORELOS: Oryzomys couesi (Brennan and Dalmat 1960). Specimens in collections: Unknown, possibly USNM. SAN LUIS POTOSÍ: El Salto: Handleyomys rostratus (recorded as Oryzomys rostratus), Reithrodontomys sp. (Hoffmann 1990). Specimens in collections: Unknown; Hoffmann collection is in the CNAC. VERACRUZ: Baiomys musculus, Peromyscus boylii, Reithrodontomys fulvescens (Brennan and Dalmat 1960). Specimens in collections: Unknown, possibly USNM. Note: P. boylii is not distributed in Veracruz according to Ceballos (2014).

Pseudoschoengastia hypopsia Brennan and Jones, 1959

CHIAPAS: 11 km NW Tuxtla Gutiérrez: Baiomys musculus (Brennan and Jones 1959). Specimens in collections: USNM. Carretera Panamericana at Río San Gregorio: Neotoma mexicana, Peromyscus mexicanus. 17 km NW Teopisca, camino a San Cristóbal Las Casas: P. boylii (Hoffmann 1990). Specimens in collections: Unknown; Hoffmann collection is in the CNAC. Note: P. boylii is not distributed in Chiapas according to Ceballos (2014).

Pseudoschoengastia pedregalensis (Hoffmann, 1951)

ESTADO DE MÉXICO: Cerro de Zucayuca, Pedregal de San Ángel, Baiomys taylori, Peromyscus gratus (recorded as $P$. truei gratus; Hoffmann 1951a, Whitaker et al. 1991). Cerca de Ojotango, Lagunas de Zempoala, Reithrodontomys sp. (Hoff- 
mann 1990). Specimens in collections: Unknown; Hoffmann collection is in the CNAC. HIDALGO: No data. Known hosts are mainly small rodents, likely cricetid and heteromyid rodents (Brennan 1960a). Specimens in collections: USNM. MICHOACÁN: No data. Known hosts are mainly small rodents, likely cricetid and heteromyid rodents (Brennan 1960a). Specimens in collections: USNM. MORELOS: Lagunas de Zempoala, 1 km NE Laguna No. 1, Mpio. de Huitzilac: Neotoma mexicana (Hoffmann 1990). Specimens in collections: Unknown; Hoffmann collection is in the CNAC. No data. Known hosts are mainly small rodents, likely cricetid and heteromyid rodents (Brennan 1960a). Specimens in collections: USNM. OAXACA: $1 \mathrm{~km} \mathrm{~S}$ and $5 \mathrm{~km} \mathrm{E}$ to Vista Hermosa, Mpio. Santiago Comaltepec: Peromyscus melanocarpus (Estébanes-González and Cervantes 2005). Specimens in collections: IBUNAM. VERACRUZ: Banderillas, $6 \mathrm{~km} \mathrm{NW}$ Xalapa, Mpio. Xalapa: Peromyscus furvus. 18 km NWTeocelo, Mpio. Ixhuacán; 5 km W Naolinco, Mpio. Naolinco: Microtus quasiater (Estébanes-González and Cervantes 2005). Specimens in collections: IBUNAM. No Data. Known hosts are mainly small rodents, likely cricetid and heteromyid rodents (Brennan 1960a). Specimens in collections: USNM.

Pseudoschoengastia scitula Brennan and Jones, 1959

CAMPECHE: $5 \mathrm{~km} \mathrm{~S}$ Champotón; 65 km S, 128 km E Escárcega: Ototylomys phyllotis. $7.5 \mathrm{~km} \mathrm{~W}$ Escárcega: Handleyomys melanotis (recorded as Oryzomys melanotis), Ototylomys phyllotis, Peromyscus leucopus, Sigmodon hispidus, Heteromys gaumeri. $7 \mathrm{~km} \mathrm{~N}, 51 \mathrm{~km}$ E Escárcega: $H$. gaumeri. 103 km SE Escárcega: Ototylomys phyllotis, H. gaumeri (Loomis 1969). Specimens in collections: Unknown, possibly FMNH. Note: $H$. melanotis and S. hispidus are not distributed in Campeche according to Ceballos (2014). A possible host includes S. toltecus (Ceballos 2014). CHIAPAS: Carretera Panamericana at Río San Gregorio: Heteromys pictus (Brennan and Jones 1959). Specimens in collections: USNM. GUERRERO: No data. Known hosts are mainly small rodents, likely cricetid and heteromyid rodents (Brennan 1960a). Specimens in collections: USNM. QUINTANA ROO: $85 \mathrm{~km}$ W Chetumal: Ototylomys phyllotis, Heteromys gaumeri. 4 km NNE Felipe Carrillo Puerto: Handleyomys melanotis (recorded as Oryzomys melanotis), Ototylomys phyllotis, H. gaumeri. Pueblo Nuevo X-Can: Ototylomys phyllotis (Loomis 1969). Specimens in collections: Unknown, possibly FMNH. Note: H. melanotis is not distributed in Quintana Roo according to Ceballos (2014). YUCATÁN: Chichén Itzá: Ototylomys phyllotis. Peto: Heteromys gaumeri. 2-3 km N Pisté: Peromyscus yucatanicus. 66 km NE Mérida: O. phyllotis, H. gaumeri (Loomis 1969). Specimens in collections: Unknown, possibly FMNH.

\section{Walchioides gouldi (Hoffman, 1954)}

CHIAPAS: Carretera Panamericana at Río San Gregorio: Peromyscus mexicanus (Hoffmann 1954). Specimens in collections: Unknown; Hoffmann collection is in the CNAC.
Walchioides inevicta (Brennan, 1960)

PUEBLA: Baiomys musculus. Popocatépetl: Neotomodon alstoni (Brennan 1960a). Specimens in collections: USNM. Izucar de Matamoros: Baiomys musculus (OSAL). Specimens in collections: OSAL.

\section{Walchioides whartoni (Brennan, 1960)}

COAHUILA: Neotoma sp., Peromyscus sp. Brennan 1960a). Specimens in collections: OSAL, USNM.

Leeuwenhoekiidae Womersley, 1944

Morelacarus cognatus (Brennan, 1966)

BAJA CALIFORNIA: Las Arrastras: Neotoma bryanti nest (Brennan 1966). Specimens in collections: USNM. Note: N. lepida from the Baja California peninsula is now recognized as N. bryanti (Patton et al. 2007).

\section{Morelacarus morelensis (Hoffmann, 1960)}

ESTADO DE MÉXICO: Cerca de Ojotongo; La Piedra; Lagunas de Zempoala: Microtus sp. (Hoffmann 1990). Specimens in collections: Unknown; Hoffmann collection is in the CNAC. GUERRERO: Omiltemi: Neotoma mexicana (Hoffmann 1990). Specimens in collections: Unknown; Hoffmann collection is in the CNAC. MORELOS: Lagunas de Zempoala, 1 km NE Laguna No.1, Mpio. de Huitzilac: Neotoma mexicana. Camino a Atzompa, vertiente sur del Cuautépetl, Mpio. de Huitzilac: Microtus mexicanus (Hoffmann 1960b). Specimens in collections: USNM, IBUNAM.

\section{Odontacarus (Tarsalacarus) bakeri (Hoffmann, 1951)}

CIUDAD DE MÉXICO: Pedregal de San Ángel: Peromyscus gratus (recorded as P. truei; Hoffmann 1951b). Specimens in collections: IBUNAM. Pedregal de San Ángel: Baiomys taylori (Brennan and Dalmat 1960). Specimens in collections: Unknown, possibly USNM or FMNH. 1 km SE Zacatepec: $P$. gratus (recorded as P. truei; Hoffmann 1990). Specimens in collections: IBUNAM. ESTADO DE MÉXICO: Gruta de la Estrella, Tonatico: Neotoma mexicana. Ojotongo, Lagunas de Zempoala: Neotoma sp. (Hoffmann 1990). Specimens in collections: IBUNAM. MICHOACÁN: $10 \mathrm{~km}$ E Zamora: Heteromys irroratus (Hoffmann 1990). Specimens in collections: IBUNAM. PUEBLA: Volcán Popocatépetl, 1 km SW San Pedro Atlixco: Peromyscus difficilis (Hoffmann 1990). Specimens in collections: IBUNAM.

Odontacarus (Tarsalacarus) chiapanensis (Hoffmann, 1948)

BAJA CALIFORNIA: Known hosts are small rodents, likely cricetid and heteromyid rodents (Goff and Loomis 1977). Unknown if specimens are in collections. QUINTANA ROO: 4 km NNE Felipe Carrillo Puerto: Ototylomys phyllotis. Pueblo Nuevo X-Cán: Peromyscus yucatanicus (Loomis 1969). Specimens in collections: FMNH. OAXACA: $11 \mathrm{~km}$ SW Esperanza 
to San Isidro, Mpio. Santago Comaltepec: Nyctomys sumichrasti (Estébanes-González and Cervantes 2005). Specimens in collections: IBUNAM.

Odontacarus (Odontacarus) kromani Goff and Loomis, 1973

BAJA CALIFORNIA: 11 km N del Cañón del Cajón, Sierra de San Pedro Mártir: Peromyscus crinitus (Goff and Loomis 1973). Specimens in collections: Unknown, possibly FMNH.

Odontacarus (Odontacarus) linsdalei (Brennan and Jones, 1954)

BAJA CALIFORNIA: Known hosts are small rodents, likely cricetid and heteromyid rodents (Goff and Loomis 1977). Unknown if specimens are in collections.

\section{Odontacarus (Tarsalacarus) micheneri (Greenberg, 1952)}

BAJA CALIFORNIA: Known hosts are small rodents, likely cricetid and heteromyid rodents (Goff and Loomis 1977). Unknown if specimens are in collections.

\section{Odontacarus (Odontacarus) tubercularis (Brennan, 1952)}

CAMPECHE: 5 km S Champotón: Heteromys gaumeri (Loomis 1969). Specimens in collections: FMNH. YUCATÁN: Chichén Itzá: Ototylomys phyllotis, Peromyscus yucatanicus, Sigmodon hispidus. Pisté: Heteromys gaumeri (Loomis 1969). Specimens in collections: FMNH. Note: S. hispidus is not distributed in Yucatán according to Ceballos (2014). A possible host includes S. toltecus (Ceballos 2014).

\section{Sasacarus furmani (Hoffmann, 1954)}

OAXACA: Monte Albán: Baiomys musculus (Hoffmann 1954). Specimens in collections: Unknown; Hoffmann collection is in the CNAC.

Sasacarus whartoni (Hoffmann, 1951)

BAJA CALIFORNIA: Arroyo de Calamajué: Peromyscus sp. (Brennan 1966). Specimens in collections: USNM. PUEBLA: Matamoros: Baiomys musculus (Hoffmann 1951b). Specimens in collections: Unknown; Hoffmann collection is in the CNAC.

\section{Whartonia guerrerensis Hoffmann, 1960}

OAXACA: $1 \mathrm{~km} \mathrm{~S}$ and $5 \mathrm{~km}$ E to Vista Hermosa, Mpio. Santiago Comaltepec: Peromyscus mexicanus. $11 \mathrm{~km} \mathrm{SW}$ of Esperanza to San Isidro, Mpio. Santiago Comaltepec: Nyctomys sumichrasti (Hoffmann 1960c; Estébanes-González and Cervantes 2005). Specimens in collections: IBUNAM.

Xenodontacarus folius Loomis and Goff, 1973

SINALOA: 2 km NE Santa Lucía: Peromyscus boylii (Loomis and Goff 1973). Specimens in collections: USNM. Note: $P$. boylii is not distributed in Sinaloa according to Ceballos (2014).
Xenodontacarus serratus Loomis and Goff, 1973

MICHOACÁN: Chorros del Varal: Osgoodomys banderanus. (Estébanes-González and Cervantes 2005). Specimens in collections: IBUNAM.

Sarcoptiformes Reuter, 1909

Infraorder: Astigmata Canestrini, 1891

Glycyphagidae Berlese, 1887

Glycyphagus hylandi (Fain, 1969)

COLIMA: Playa de Oro: Baiomys musculus (EstébanesGonzález et al. 2011). Specimens in collections: IBUNAM. Note: This is likely a misidentification; G. hylandi is normally associated with the eastern chipmunk in the United States.

Glycyphagus hypudaei hypudaei (Koch, 1841)

CHIAPAS: Cerro Tzontehuitz, 12 km NE of San Cristóbal de las Casas, Mpio. San Juan Chamula: Reithrodontomys microdon (Estébanes-González and Cervantes 2005). Specimens in collections: IBUNAM. OAXACA: 1 km N of Esperanza, Mpio. Santiago Comaltepec, Distrito Ixtlán and $3 \mathrm{~km}$ SE of Totontepec, Mpio. Totontepec: Peromyscus melanocarpus, Reithrodontomys mexicanus. Cerro Zempoaltepetl, 4 km E of Yacochi, Mpio. Tlahuitoltepec: Handleyomys alfaroi (recorded as Oryzomys alfaroi; Estébanes-González and Cervantes 2005). Specimens in collections: IBUNAM. VERACRUZ: $18 \mathrm{~km} \mathrm{NW}$ of Teocelo, Mpio. Ixhuacán; 300 km NW Cascadas Teocelo, 1.5 km SE Xico, Mpio. Xico: Microtus quasiater. Banderillas, 6 km NW of Xalapa, Mpio. Xalapa: Peromyscus furvus (Estébanes-González and Cervantes 2005). Specimens in collections: IBUNAM.

Glycyphagus liomys (Fain and Ide, 1978)

JALISCO: $9.8 \mathrm{mi}$ W of Atenquique: Heteromys irroratus (Fain and Ide 1978). Specimens in collections: USNM. Chamela Biological Station: Heteromys pictus (GómezRodríguez et al. 2015). Specimens in collections: CNAC. NOTE: This species was originally described in the genus Dermacarus, but it has not yet been formally recombined.

\section{Glycyphagus mexicanus (Fain, 1969)}

OAXACA: Ilacolula: Baiomys musculus (Fain 1969). Specimens in collections: NHM. NOTE: This species was originally described in the genus Dermacarus, but it has not yet been formally recombined.

\section{Glycyphagus ornatus (Fain, 1967)}

YUCATÁN: 3 km N of Pisté; 2 km E of Chichén Itzá: Heteromys gaumeri (Pence and Genoways 1974). Specimens in collections: USNM. NOTE:This species was originally described in the genus Dermacarus, but it has not yet been formally recombined. Recombination into Glycyphagus renders the 
name a junior secondary homonym of Glycyphagus ornatus Kramer, 1881.

Neolabidophorus verrucosus Fain and Lukoschus, 1978

ESTADO DE MÉXICO: Chaetodipus penicillatus (Fain and Lukoschus 1978). Specimens in collections: MNHN. Note: C. penicillatus is not distributed in Estado de México according to Ceballos (2014).

Neolabidophorus yucatanensis Pence and Genoways, 1974

YUCATÁN: 3 km N of Pisté: Heteromys gaumeri (Pence and Genoways 1974). Specimens in collections: USNM.

Histiostomatidae Kramer, 1876

Histiostoma tienhoveni (Oudemans, 1926)

CHIAPAS: Cerro Tzontehuitz, 13 km NE of San Critobal de las Casas, Mpio. San Juan Chamula: Peromyscus zarhynchus (Estébanes-González and Cervantes 2005). Specimens in collections: IBUNAM. Note: This species has been synonymized with Rhopalanoetus fimetarium (Canestrini and Berlese, 1881). It is a common inhabitant of cattle dung wherever people have taken them. It is typically phoretic on dung beetles, so the mammal associations are problematic - in this case, the species is probably misidentified.

Listrophoridae Canestrini, 1892

Geomylichus bassolsi Servín et al., 1992

BAJA CALIFORNIA SUR: Isla Cerralvo: Chaetodipus siccus (Servín et al. 1992). Specimens in collections: IBUNAM. Note: Chaetodipus arenarius was recognized as the original host. However, C. arenarius from the costal plains of the southern part of the tip of the Baja california peninsula is now recognized as C. siccus (Álvarez-Castañeda and Ríos 2011).

Geomylichus brevispinosus Fain et al., 1978

ZACATECAS: 4.3 km N, 5.4 km E of San Juan Capistrano; $0.8 \mathrm{~km} \mathrm{~N}, 0.4 \mathrm{~km} \mathrm{~W}$ of San Juan Capistrano: Chaetodipus nelsoni (Vargas et al. 1999). Unknown if specimens are in collections.

Geomylichus comitanensis Hoffmann and Servín, 1990

BAJA CALIFORNIA SUR: Comitán: Chaetodipus amophilus (Hoffmann and Servín 1990). Specimens in collections: CIB and possibly CNAC (Hoffmann collection is in the CNAC).

Geomylichus dipodomius (Radford, 1953)

COAHUILA: 5.4 mi W of General Cepeda: Dipodomys nelsoni (Fain et al. 1991; Vargas-Sandoval et al. 1991). Unknown if specimens are in collections. DURANGO: $0.2 \mathrm{~km} \mathrm{~S}, 1.5 \mathrm{~km}$ W of Villa Hidalgo; $1.3 \mathrm{~km} \mathrm{S,} 0.7 \mathrm{~km}$ W of Laboratorio del Desierto; $4.3 \mathrm{~km} \mathrm{~N}, 2.8 \mathrm{~km} \mathrm{~W}$ of Laboratorio del Desierto:
Dipodomys nelsoni (Vargas et al. 1999). Mapimí: D. nelsoni (Vargas et al. 2005). Unknown if specimens are in collections. NUEVO LEÓN: $4.6 \mathrm{~km} \mathrm{~N}, 14.0 \mathrm{~km}$ E of Jesús de Berrones; $1.7 \mathrm{~km} \mathrm{~N}, 10 \mathrm{~km} \mathrm{~W}$ of San Josecito; $4.0 \mathrm{~km} \mathrm{~S}, 3.3 \mathrm{~km}$ W of Puerto Carretas: Dipodomys nelsoni (Vargas et al. 1999). Unknown if specimens are in collections. SAN LUIS POTOSÍ: 6.0 km NE of La Palma Pegada: Dipodomys spectabilis. 21.4 $\mathrm{km} \mathrm{S}$ of Matehuala; $2.0 \mathrm{~km} \mathrm{~N}, 0.4 \mathrm{~km} \mathrm{~W}$ of El Cedral: D. nelsoni (Vargas et al. 1999). Catorce: D. ornatus (recorded as $D$. phillipsii; Fain et al. 1978; Fain and Whitaker 1987). Unknown if specimens are in collections. Note: D. phillipsii from San Luis Potosí is now recognized as D. ornatus (Fernández et al. 2012).

Geomylichus durangoensis (Vargas et al., 1999)

DURANGO: $2.6 \mathrm{~km} \mathrm{~S}, 0.4$ km E of Laboratorio del Desierto: Chaetodipus nelsoni (Vargas et al. 1999). Mapimí: C. nelsoni (Vargas et al. 2005). Specimens in collections: CNAC, NHM.

Geomylichus guaycurensis Servín et al., 1994

BAJA CALIFORNIA SUR: 17 km NE of La Paz: Chaetodipus ammophilus (Servín et al. 1994). Specimens in collections: IBUNAM. Note: Chaetodipus arenarius was recognized as the original host. However, C. arenarius from the costal plains of the southern part of the tip of the Baja california peninsula is now recognized as C. ammophillus (Álvarez-Castañeda and Ríos 2011; Rios and Álvarez-Castañeda 2013).

Geomylichus hispidus Vargas et al., 1999

NUEVO LEÓN: Linares: Chaetodipus hispidus (Vargas et al. 2005). Unknown if specimens are in collections. ZACATECAS: $1.3 \mathrm{~km} \mathrm{~N}, 6.0 \mathrm{~km}$ W of Chalchihuites: Chaetodipus hispidus (Vargas et al. 1999). Unknown if specimens are in collections.

Geomylichus nelsoni Vargas et al., 1999

DURANGO: 0.2 km S, 1.5 km W of Villa Hidalgo: Chaetodipus nelsoni (Vargas et al. 1999). Unknown if specimens are in collections. NUEVO LEÓN: $3.4 \mathrm{~km} \mathrm{~N}, 9.2 \mathrm{~km}$ W of San Josecito; 8 km N, 4.1. km E of San Josecito: Chaetodipus nelsoni (Vargas et al. 1999). Unknown if specimens are in collections. SAN LUIS POTOSÍ: $2.0 \mathrm{~km} \mathrm{~N}, 0.4 \mathrm{~km} \mathrm{~W}$ of el Cedral; $4 \mathrm{~km} \mathrm{~W}$ of Villa de Arreaga, Real de Catorce: Chaetodipus nelsoni (Vargas et al. 1999; Vargas et al. 2005). Unknown if specimens are in collections. ZACATECAS: San Juan Capistrano: Chaetodipus nelsoni (Vargas et al. 2005). Unknown if specimens are in collections.

\section{Geomylichus oaxacae Fain and Estébanes, 2000}

OAXACA: Mpio. Santa María Chimalapas: Heteromys desmarestianus (Fain and Estébanes 2000; Estébanes-González and Cervantes 2005). Specimens in collections: IBUNAM. 
Geomylichus penicillatus Vargas et al., 1999

DURANGO: $4.3 \mathrm{~km} \mathrm{~N}, 2.8 \mathrm{~km}$ W of Laboratorio del Desierto: Chaetodipus penicillatus (Vargas et al. 1999). Mapimí: C. penicillatus (Vargas et al. 2005). Specimens in collections: CNAC, NHM. Note: C. penicillatus is not distributed in Durango according to Ceballos (2014).

Geomylichus perognathi Fain and Whitaker, 1980

CHIHUAHUA: Casas Grandes: Perognathus flavus (Vargas et al. 1999). Unknown if specimens are in collections. DURANGO: $0.2 \mathrm{~km} \mathrm{S,} 1.5 \mathrm{~km} \mathrm{~W}$ of Villa Hidalgo, Vicente Guerero: Perognathus flavus (Vargas et al. 1999, Vargas et al. 2005). Unknown if specimens are in collections. NUEVO LEÓN: 11 km SW of China: Perognathus merriami. 0.8 km S, 0.9 km W of Jesús de Berrones: P. flavus (Vargas et al. 1999). Unknown if specimens are in collections.

\section{Geomylichus postscutatus Fain, 1976}

COLIMA: Cabano: Heteromys irroratus (Fain et al. 1978). Playa de Oro: $H$. irroratus, $H$. pictus (Estébanes-González et al. 2011). Specimens in collections: IBUNAM. DURANGO: Vicente Guerrero: Heteromys irroratus (Vargas et al. 2005). Unknown if specimens are in collections. JALISCO: Chamela Biological Station: Heteromys pictus (Gómez-Rodríguez et al. 2015). Specimens in collections: CNAC. $1.3 \mathrm{~km}$ S, $5.5 \mathrm{~km}$ W of Huejuquilla El Alto: $H$. irroratus (Vargas et al. 1999). Unknown if specimens are in collections. NUEVO LEÓN: $8.0 \mathrm{~km} \mathrm{~N}, 4.1 \mathrm{~km}$ E of San Josecito; $0.3 \mathrm{~km} \mathrm{S,} 6.2 \mathrm{~km}$ W of Huejuquilla El Alto: Heteromys irroratus (Vargas et al. 1999). Unknown if specimens are in collections. OAXACA: Dainzú: Heteromys irroratus (Vargas et al. 2005). Unknown if specimens are in collections.

Geomylichus texanus Fain et al., 1978

DURANGO: $0.2 \mathrm{~km} \mathrm{S,} 1.5 \mathrm{~km}$ W of Villa Hidalgo; $0.1 \mathrm{~km}$ $\mathrm{N}, 0.7 \mathrm{~km}$ W of Laboratorio del Desierto: Dipodomys merriami, D. ordii (Vargas et al. 1999). Vicente Guerrero: D. ornatus (recorded as D. phillipsii; Vargas et al. 2005). Unknown if specimens are in collections. Note: D. phillipsii from Durango is now recognized as $D$. ornatus (Fernández et al. 2012). NUEVO LEÓN: 3.4 km N, 9.2 km W of San Josecito; 0.8 km S, 0.9 km W of Jesús María de Berrones: Dipodomys merriami, D. ordii (Vargas et al. 1999). Unknown if specimens are in collections. SAN LUIS POTOSí: $4.0 \mathrm{~km} \mathrm{~W}$ of Villa de Arreaga: Dipodomys ordii. $2.0 \mathrm{~km} \mathrm{~N}, 0.4 \mathrm{~km} \mathrm{~W}$ of El Cedral: D. merriami (Vargas et al. 1999). Real de Catorce: D. merriami, D. ordii (Vargas et al. 2005). Unknown if specimens are in collections. ZACATECAS: $1.3 \mathrm{~km} \mathrm{~N}, 6.0 \mathrm{~km} \mathrm{~W}$ of Chalchihuites: Dipodomys ornatus (recorded as D. phillipsii; Vargas et al. 1999). Note: D. phillipsii from Zacatecas is now recognized as D. ornatus (Fernández et al. 2012). Unknown if specimens are in collections.
Listrophorus mexicanus Fain, 1970

DURANGO: Microtus mexicanus (Fain 1970, Fain and Hyland 1974). Specimens in collections: NHM.

Listrophorus pitymys Fain and Hyland, 1972

OAXACA: Cerro Zempoaltepetl, $5 \mathrm{~km} \mathrm{~N}$ of Yacochi, Mpio. Tlhuitoltepec: Microtus umbrosus, Reithrodontomys sp. (Estébanes-González and Cervantes 2005). Specimens in collections: IBUNAM. VERACRUZ: 18 km NW of Teocelo, Mpio. Ixhuacán: Microtus quasiater (Estébanes-González and Cervantes 2005). Specimens in collections: IBUNAM.

Prolistrophorus bakeri (Radford, 1949)

COLIMA: Playa de Oro: Oryzomys couesi, Reithrodontomys fulvescens, Sigmodon mascotensis (Estébanes-González et al. 2011). Specimens in collections: IBUNAM.

\section{Prolistrophorus frontalis (Hirst, 1921)}

COLIMA: Playa de Oro: Baiomys musculus, Handleyomys melanotis (recorded as O. melanotis), Nyctomys sumichrasti, Oryzomys couesi, Osgoodomys banderanus (EstébanesGonzález et al. 2011). Specimens in collections: IBUNAM. VERACRUZ: 18 km NW of Teocelo, Mpio. Ixhuacán: Oligoryzomys fulvescens (recorded as Oryzomys fulvescens; Estébanes-González and Cervantes 2005). Specimens in collections: IBUNAM.

\section{Prolistrophorus pernamboucensis (Fain, 1973)}

OAXACA: Cerro Zempoaltépetl, 5 km E of Santa María Yacochi, Mpio. Tlahuitoltepec: Peromyscus sp. (EstébanesGonzález and Cervantes 2005). Specimens in collections: IBUNAM.

Prolistrophorus sclerobursatus (Fain and Estébanes, 1996)

JALISCO: Chamela Biological Station: Heteromys pictus (Gómez-Rodríguez et al. 2015). Specimens in collections: CNAC. OAXACA: Cerro Zempoaltépetl, $5 \mathrm{~km}$ E of Santa María Yacochi, Mpio. Tlahuitoltepec: Peromyscus sp., Reithrodontomys sp. (Estébanes-González and Cervantes 2005). Specimens in collections: IBUNAM. VERACRUZ: 18 km NW of Teocelo, Mpio. Ixhuacán: Microtus quasiater. Banderillas, 6 km NW of Xalapa, Mpio. Xalapa: Peromyscus furvus (Estébanes-González and Cervantes 2005). Specimens in collections: IBUNAM.

Myocoptidae Gunther, 1942

Myocoptes glareoli Samsinak, 1957

VERACRUZ: 18 km NW of Teocelo, Mpio. Ixhuacán: Microtus quasiater (Estébanes-González and Cervantes 2005). Specimens in collections: IBUNAM. 
Myocoptes musculinus (Koch, 1840)

COLIMA: Playa de Oro: Reithrodontomys fulvescens (Estébanes-González et al. 2011). Specimens in collections: IBUNAM. SAN LUIS POTOSÍ: Rancho "El Estribo," 10 km SE of El Naranjo, Mpio. Ciudad del Maíz: Sigmodon hispidus (Estébanes-González and Cervantes 2005). Specimens in collections: IBUNAM. Note: S. hispidus is not distributed in San Luis Potosí according to Ceballos (2014). A possible alternative host includes S. leucotis (Ceballos 2014).

Phylum: Arthropoda von Siebold, 1848

Class: Insecta Linnaeus, 1758

Order: Phthiraptera Haekel, 1896

Suborder: Anoplura Leach, 1815

Family: Hoplopleuridae Ewing, 1929

Hoplopleura acanthopus (Burmeister, 1839)

NUEVO LEÓN: El Potosí: Microtus mexicanus (Emerson 1971). Specimens in collections: SNOW, USNM.

Hoplopleura arizonensis Stojanovich and Pratt, 1961

COAHUILA: Parras; Paila-Parras: Sigmodon toltectus (Emerson 1971). Specimens in collections: SNOW, USNM. Note: S. toltectus is not distributed in Coahuila according to Ceballos (2014). YUCATÁN: Pisté: Sigmodon toltecus (Emerson 1971). Specimens in collections: SNOW, USNM.

\section{Hoplopleura difficilis Kim, 1965}

MORELOS: Lagunas de Zempoala: Peromyscus difficilis (L. A. Durden unpub. data, Sánchez-Montes et al. 2013). No specimens in collections.

Hoplopleura emphereia Kim, 1965

CHIAPAS: Union Juárez: Peromyscus guatemalensis (Emerson 1971). Specimens in collections: SNOW, USNM. GUERRERO: Omiltemi: Peromyscus megalops (Emerson 1971). Specimens in collections: SNOW, USNM. Parque Estatal Cerro del Huizteco: Peromyscus megalops (Sánchez-Montes et al. 2016a). Specimens in collections: LFAC. JALISCO: Ciudad Guzmán: Peromyscus sp. (Emerson 1971). Specimens in collections: SNOW, USNM. OAXACA: Cerro Pelón: Megadontomys cryophilus (Emerson 1971). Specimens in collections: SNOW, USNM. $3 \mathrm{~km}$ al Sur de El Punto Ixtepeji: Peromyscus megalops. Oaxaca-Tuxtepec, km 134.5 de la Carretera 175: Peromyscus aztecus (Sánchez-Montes et al. 2016a). Specimens in collections: LFAC.

\section{Hoplopleura ferrisi Cook and Beer, 1959}

DURANGO: El Salto: Peromyscus spicilegus (Emerson 1971). Specimens in collections: SNOW, USNM. JALISCO: Zapotlanejo, Nevado de Colima: Peromyscus levipes (Emerson 1971). Specimens in collections: SNOW, USNM. Note: $P$. levipes is not distributed in Jalisco according to Cebal- los (2014). MORELOS: Lagunas de Zempoala: Peromyscus sp. (Emerson 1971). Specimens in collections: SNOW, USNM. NAYARIT: "Tepico": Peromyscus spicilegus (Emerson 1971). Specimens in collections: SNOW, USNM. OAXACA: La Yerba-Buena, Mpio. de Santa Catarina Juquila: Peromyscus melanurus (Sánchez-Montes et al. 2013). Specimens in collections: CPFC. La Yerba-Buena: P. aztecus, P. melanurus (Sánchez-Montes et al. 2016a). Specimens in collections: LFAC. SINALOA: Peromyscus spicilegus (Emerson 1971). Specimens in collections: SNOW, USNM.

\section{Hoplopleura hesperomydis (Osborn, 1891)}

CHIHUAHUA: El Paso-Chihuahua City highway, about 55 km S of Ciudad Juárez: Onychomys leucogaster (Morlan and Hoff 1957). No specimens in collections. Note: This is considered an unusual and unlikely host-louse association. Note: O. leucogaster is not distributed in Chihuahua according to Ceballos (2014). ESTADO DE MÉXICO: Nevado de Toluca: Peromyscus melanotis (Emerson 1971). Specimens in collections: SNOW, USNM. JALISCO: Nevado de Colima: Peromyscus melanotis (Emerson 1971). Specimens in collections: SNOW, USNM.

\section{Hoplopleura hirsuta Ferris, 1916}

CHIAPAS: San Clemente; Tapachula: Sigmodon hirsutus (Emerson 1971). Specimens in collections: SNOW, USNM. CHIHUAHUA: Parral: Sigmodon ochrognathus (Ferris 1921; Sánchez-Montes et al. 2013). Specimens in collections: USNM. COLIMA: Hacienda Magdalena: Xenomys nelsoni (Ferris 1921; Sánchez-Montes et al. 2013). No specimens in collections. Note: Considered an unusual host-louse association. Sánchez-Montes et al. (2013) also reported H. hirsuta from Neotoma micropus, which likely represents contamination or a host or louse misidentification. NUEVO LEÓN: Pesquería: Sigmodon toltecus (Ramos-Casillas 2003; Sánchez-Montes et al. 2013). No specimens in collections. Note: S. toltecus is not distributed in Nuevo León according to Ceballos (2014). SAN LUIS POTOSÍ: El Salto: Sigmodon toltecus (Emerson 1971). Obregón; Miguel del Naranjo: $S$. hispidus (Sánchez-Montes et al. 2016b). Specimens in collections: SNOW, USNM. Note: S. hispidus is not distributed in San Luis Potosí according to Ceballos (2014). A possible alternative host includes S. leucotis (Ceballos 2014). SINALOA: Los Mochis: Sigmodon arizonae (Emerson 1971). Specimens in collections: SNOW, USNM. TAMAULIPAS: Matamoros: Neotoma micropus (Ramos-Casillas 2003; SánchezMontes et al. 2013). No specimens in collections. Note:This is considered an unusual host-louse association.

Hoplopleura quadridentata (Neumann, 1909)

TAMAULIPAS: Altamira: Handleyomys rostratus (recorded as Oryzomys rostratus; Ferris 1921; Sánchez-Montes et al. 2013). Specimens in collections: USNM. VERACRUZ: Orizaba: Oligoryzomys fulvescens (recorded as Oryzomys fulvescens; Ferris 1921). Specimens in collections: USNM. 
Hoplopleura reithrodontomydis Ferris, 1951

CIUDAD DE MÉXICO: Ajusco, near México City: Reithrodontomys chrysopsis (Ferris 1951). No specimens in collections. GUERRERO: Parque Estatal Cerro del Huizteco: Habromys schmidlyi, Reithrodontomys bakeri, R. sumichrasti (Sánchez-Montes et al. 2016a). Specimens in collections: LFAC. OAXACA: La Yerba-Buena; Oaxaca-Tuxtepec, km 134.5 de la Carretera 175: Reithrodontomys mexicanus (Sánchez-Montes et al. 2016a). Specimens in collections: LFAC.

\section{Hoplopleura similis Kim, 1965}

VERACRUZ: Orizaba: Oligoryzomys fulvescens (Kim 1965). Specimens in collections: USNM.

Polyplacidae Fahrenholz, 1912

Fahrenholzia boleni McDaniel, 1968

COAHUILA: Plan de Guadalupe: Perognathus merriami (Light and Hafner 2007). Specimens in collections: Price Institute.

\section{Fahrenholzia ehrlichi Johnson, 1962}

HIDALGO: Ixmiquilpan: Heteromys irroratus (Emerson 1971). Specimens in collections: SNOW, USNM. JALISCO: $16 \mathrm{~km} \mathrm{N-NE}$ of Ameca: Heteromys irroratus (Light and Hafner 2007). Specimens in collections: Price Institute. Etzatlán: H. irroratus (Emerson 1971). Specimens in collections: SNOW, USNM. Acotlán; Atamajec; Encarnación de Díaz: H. irroratus (Johnson 1962). Specimens in collections: USNM. Chamela Biological Station: H. pictus (Gómez-Rodríguez et al. 2015). Specimens in collections: CNAC. PUEBLA: $11 \mathrm{~km}$ (by road) SW of Alchichica; 3 km (by road) NE of Tilapa; 6 km N of Tilapa: Heteromys irroratus (Light and Hafner 2007). Specimens in collections: Price Institute. SAN LUIS POTOSÍ: El Salto: Heteromys irroratus (Emerson 1971). Specimens in collections: SNOW, USNM. TAMAULIPAS: Matamoros: Heteromys irroratus (Johnson 1962). No specimens in collections. ZACATECAS: 2 mi E of San Jerónimo: Heteromys irroratus (Light and Hafner 2007). Specimens in collections: Price Institute. Valparaíso: H. irroratus (Johnson 1962). Specimens in collections: USNM. Note: SánchezMontes et al. (2013) also list Chaetodipus hispidus and C. penicillatus (Heteromyidae) as hosts of Fahrenholzia ehrlichi in their host-louse list, but no such association could be found in their list by Mexican state. Johnson (1962) notes that paratypes are also in the collections of the British Museum (Natural History; now the Natural History Museum, London) and the Stanford University Natural History Museum.

Fahrenholzia ferrisi Werneck, 1952

VERACRUZ: Achotal: Heteromys desmarestianus, H. desmarestianus (recorded as H. goldmani; Werneck 1952; John- son 1962). Specimens in collections: USNM. $8 \mathrm{~km}$ E-NE of Catemaco: H. desmarestianus (Light and Hafner 2007). Specimens in collections: Price Institute. YUCATÁN: Pisté: Heteromys gaumeri (Emerson 1971). Specimens in collections: SNOW, USNM.

\section{Fahrenholzia hertigi, Johnson, 1962}

VERACRUZ: 8 km E-NE of Catemaco: Heteromys desmarestianus (Light and Hafner 2007). Specimens in collections: Price Institute.

\section{Fahrenholzia microcephala Ferris, 1922}

GUERRERO: Parque Estatal Cerro del Huizteco, Mpio. de Taxco: Heteromys pictus (Sánchez-Montes et al. 2013; 2016a). Specimens in collections: CPFC, LAFC. JALISCO: Atamejac: Heteromys irroratus (Ferris 1922). Specimens in collections: USNM. $4.5 \mathrm{~km}$ SW of Jilotlán: H. pictus (Light and Hafner 2007). Specimens in collections: Price Institute. NAYARIT: Tepic: Heteromys pictus (Emerson 1971). Specimens in collections: SNOW, USNM. SINALOA: Matatán; San Ignacio; Santa Lucía: Heteromys pictus (Emerson 1971). Specimens in collections: SNOW, USNM. VERACRUZ: San Carlos: Heteromys pictus. Achotal: $H$. desmarestianus (recorded as $H$. goldmani). Valparaiso: H. irroratus (Ferris 1922). Specimens in collections: USNM, FMNH. Biological Station La Mancha: H. pictus (Light and Hafner 2007). Specimens in collections: Price Institute.

\section{Fahrenholzia pinnata Kellogg and Ferris, 1915}

CHIHUAHUA: about $55 \mathrm{~km} \mathrm{~S}$ of Ciudad Juárez along the El Paso-Chihuahua City highway: Chaetodipus penicillatus, Dipodomys merriami (Morlan and Hoff 1957). No specimens in collections. 6 mi NW of Ricardo Flores Magón: $D$. merriami (Light and Hafner 2007). Specimens in collections: Price Institute. Note: C. penicillatus is not distributed in Chihuahua according to Ceballos (2014). COAHUILA: Paila: Dipodomys sp. (Emerson 1971). Specimens in collections: SNOW, USNM. 2 mi E of Agua Nueva: Dipodomys ordii. $5 \mathrm{~km} \mathrm{~S}, 16 \mathrm{~km}$ W of General Cepeda: D. nelsoni. $2 \mathrm{~km} \mathrm{~S}$ of Santa Teresa: D. merriami (Light and Hafner 2007). Specimens in collections: Price Institute. ESTADO DE MÉXICO: Amecameca: Dipodomys phillipsii (Ferris 1922). Specimens in collections: USNM. PUEBLA: $11 \mathrm{~km}$ (by road) SW of Alchichica: D. phillipsii. $3.1 \mathrm{~km}$ SW of El Veladero: Perognathus flavus (Light and Hafner 2007). Specimens in collections: Price Institute. SONORA: Kino: Dipodomys merriami, D. deserti (Emerson 1971). Specimens in collections: SNOW, USNM. ZACETECAS: Valparaíso: Dipodomys ornatus (Ferris 1922). No specimens in collections. $1 \mathrm{mi} \mathrm{SE}$ of Bañon: D. ordii. 2 mi E of San Jerónimo: D. phillipsii (Light and Hafner 2007). Specimens in collections: Price Institute.

Fahrenholzia reducta Ferris, 1922

BAJA CALIFORNIA SUR: Miraflores: Chaetodipus rudinoris 
(Emerson 1971). Specimens in collections: SNOW, USNM. Note: Chaetodipus baileyi was recognized as the original host. However, according to Riddle et al. (2000), C. baileyi from the Baja California peninsula are now recognized as $C$. rudinoris.

Fahrenholzia texana Stojanovich and Pratt, 1961

DURANGO: Hacienda Atotonilco: Heteromys irroratus (Light and Hafner 2007). Specimens in collections: Price Institute. JALISCO: Chamela Biological Station: Heteromys pictus (Gómez-Rodríguez et al. 2015). Specimens in collections: CNAC. OAXACA: Heteromys irroratus (Kim et al. 1986; Sánchez-Montes et al. 2013). No specimens in collections.

Fahrenholzia zacatecae Ferris, 1922

COAHUILA: $5 \mathrm{~km} \mathrm{~S}, 16 \mathrm{~km}$ W of General Cepeda: Chaetodipus hispidus (Light and Hafner 2007). Specimens in collections: Price Institute. ZACATECAS: Valparaiso: Chaetodipus hispidus (Ferris 1922). Specimens in collections: USNM. C. hispidus (Kim et al. 1986). No specimens in collections.

Neohaematopinus neotomae Ferris, 1942

COLIMA: Manzanillo: Hodomys alleni (Ferris 1942). Specimens in collections: USNM. GUERRERO: Parque Estatal Cerro del Huizteco: Neotoma mexicana (Sánchez-Montes et al. 2016a). Specimens in collections: LFAC. NUEVO LEÓN: Doctor Arroyo: Neotoma leucodon. Lampazos: N. micropus (Ramos-Casilla 2003). No specimens in collections. SINALOA: Concepción: Hodomys alleni (Emerson 1971). Specimens in collections: SNOW, USNM.

\section{Neohaematopinus sp.}

DURANGO: At border with Sinaloa: Neotoma mexicana (Emerson 1971). Specimens in collections: SNOW, USNM. SINALOA: Los Mochis: Neotoma phenax (Emerson 1971). Specimens in collections: SNOW, USNM. Note: SánchezMontes et al. (2013) recorded Neohaematopinus sciurinus ex Hodomys alleni, which must represent contamination or a louse or host misidentification.

\section{Polyplax alaskensis Ewing, 1927}

JALISCO: Nevado de Colima: Microtus mexicanus (Emerson 1971). Specimens in collections: SNOW, USNM. MORELOS: Lagunas de Zempoala: Microtus mexicanus (Emerson 1971). Specimens in collections: SNOW, USNM. NUEVO LEÓN: El Potosí: Microtus mexicanus (Emerson 1971). Specimens in collections: SNOW, USNM. OAXACA: Llano de las Flores: Microtus mexicanus (Emerson 1971). Specimens in collections: SNOW, USNM.

Polyplax auricularis Kellogg and Ferris, 1915

CHIAPAS: Tzontehuitz: Peromyscus zarhynchus (Emer- son 1971). Specimens in collections: SNOW, USNM. CIUDAD DE MÉXICO: Neotomodon alstoni (Ferris 1923). Specimens in collections: USNM. DURANGO: Ojo Tongo: Peromyscus sp., P. maniculatus. Buenos Aires: Peromyscus difficilis (Emerson 1971). Specimens in collections: SNOW, USNM. ESTADO DE MÉXICO: Nevado de Toluca: Peromyscus melanotis (Emerson 1971). Specimens in collections: SNOW, USNM. GUERRERO: Parque Estatal Cerro del Huizteco: Peromyscus beatae, P. megalops (Sánchez-Montes et al. 2016a). Specimens in collections: LFAC. JALISCO: Nevado de Colima: Peromyscus hylocetes, P. melanotis (Emerson 1971). Specimens in collections: SNOW, USNM. NUEVO LEÓN: Cerro Potosí: Peromyscus maniculatus (Emerson 1971). Specimens in collections: SNOW, USNM. OAXACA: Totontepec: Reithrodontomys mexicanus (Ferris 1923). Specimens in collections: USNM. $21 \mathrm{~km} \mathrm{~N}$ of Guelatao: Peromyscus beatae (Sánchez-Montes et al. 2013). Specimens in collections: CPFC. 3 km S of Eñ Punto Ixtepeji; Oaxaca-Tuxtepec, km 134.5 de la Carretera 175: P. beatae (Sánchez-Montes et al. 2016a). Specimens in collections: LFAC.

Phylum: Arthropoda von Siebold, 1848

Class: Insecta Linnaeus, 1758

Order: Siphonaptera Latreille, 1825

Family: Ceratophyllidae Dampf, 1908

Subfamily: Ceratophyllinae Dampf, 1908

Amaradix euphorbi (Rothschild, 1905)

NUEVO LEÓN: Cerro Potosí: Peromyscus melanotis, Peromyscus sp. (Fox 1939; Tipton and Mendez 1968). Unknown if specimens are in collections. Note: This species is also in the literature as Malaraeus euphorbi.

\section{Baculomeris schmidti (Traub, 1950)}

CHIAPAS: Pueblo Nuevo: Neotoma mexicana (Hubbard 1958). Specimens in collections: Unknown, possibly BMNH. Tonala, El Triunfo: Peromyscus sp. (recorded as Peromyscus chiapanensis; Acosta et al. 2008). Specimens in collections: MZFC.

\section{Ceratophyllus coahuilensis Eads, 1956}

GUERRERO: San Miguel Totolapan, Puerto del Gallo: Peromyscus megalops (Acosta et al. 2008). Specimens in collections: MZFC.

Jellisonia (Jellisonia) breviloba barrerai Hastriter, 2004

CIUDAD DE MÉXICO: Meyehualco, 5 km E of Santa Cruz: Peromyscus difficilis. Cerro Zacayuca: P. gratus (recorded as P. truei gratus). 21 ? [sic] W of Zacatepec: P. maniculatus (Hastriter 2004). Specimens in collections: BMNH, MZFC, REL. GUERRERO: Chilpancingo de los Bravo, $0.5 \mathrm{~km}$ W of Omiltemi: Peromyscus aztecus. Chilpancingo de los Bravo, Omiltemi: Megadontomys thomasi (Acosta et al. 2008). 
Specimens in collections: MZFC. MICHOACÁN: Coalcoman de Vázquez Pallares, Pallares 11.84 km SW of Dos Aguas: Peromyscus winkelmanni. Taxco de Alarcón, Parque Estatal El Huizteco: P. levipes (Acosta et al. 2008). Specimens in collections: MZFC. MORELOS: Lagunas de Zempoala, near Ojo de Agua: Peromyscus difficilis. Derrame Chichuinautzin: Neotoma mexicana, P. difficilis (Hastriter 2004). Specimens in collections: CMNH. OAXACA: Santiago Nacaltepec, San Lorenzo Pápalo: Peromyscus aztecus (Acosta et al. 2008). Specimens in collections: MZFC. PUEBLA: $1 \mathrm{~km}$ SW of San Pedro Atlixco: Peromyscus difficilis (Hastriter 2004). Specimens in collections: BMNH, CMNH, MZFC, REL. $2 \mathrm{~km} \mathrm{~W}$ Guadalupe Victoria, Mpio. de Guadalupe Victoria: P. maniculatus (Falcón-Ordaz et al. 2012). Specimens in collections: MZFC. QUERÉTARO: Pinal de Amoles, Chuvegé: Peromyscus sp. (Acosta et al. 2008). Specimens in collections: MZFC. TLAXCALA: Sanctorum de Lázaro Cárdenas, Camino Rural Beninto Juárez, La Joya: Peromyscus sp. (Acosta et al. 2008). Specimens in collections: MZFC. ORIENTAL BASIN: Multiple localities in Veracruz and Tlaxcala: Peromyscus difficilis, $P$. maniculatus (Acosta and Fernández 2015). Specimens in collections: MZFC.

Jellisonia (Jellisonia) breviloba breviloba Traub, 1950

COAHUILA: La Carbonara, 16 km SE of Arteaga: Peromyscus sp. (Hastriter 2004). Specimens in collections: CMNH. CIUDAD DE MÉXICO: "Country club": Neotoma mexicana. Pedregal de San Angel: Peromyscus sp. (Hastriter 2004). Specimens in collections: $\mathrm{CMNH}$, FMNH, REL. San Andrés Tetepilco: Microtus mexicanus (Ayala-Barajas et al. 1988; Hastriter 2004). Specimens in collections: BMNH, CMNH, MZFC, USNM. Cerro Zacayuca: Peromyscus gratus (recorded as both P. gratus and P. truei; Barrera 1953, Hastriter 2004). Specimens in collections: BMNH, CMNH, MZFC. Calzada de Tlalpan: M. mexicanus (Muñiz et al. 1981). Calzada de Tlalpan, near the Country Club, $1 \mathrm{~m}$ Topotipo: M. mexicanus. $400 \mathrm{~m} \mathrm{~N}, 21 \mathrm{~W}$ of Zacatepec: P. maniculatus (Ayala-Barajas et al. 1988). Specimens in collections: MZFC. DURANGO: $16 \mathrm{~km} \mathrm{~W}$ of El Salto; $0.8 \mathrm{~km}$ SE of Buenos Aires, $6.5 \mathrm{~km} \mathrm{~S}$ of El Salto; $11 \mathrm{~km} \mathrm{~S}$ of El Salto; $1.6 \mathrm{~km} \mathrm{SW}$ of Revolcaderos; 8 km E Revolcaderos; 8 km E of Revolcaderos near Sinaloa border; $9.7 \mathrm{~km} \mathrm{NE}$ of Revolcaderos; $11 \mathrm{~km} \mathrm{NE}$ of Revolcaderos; $3.2 \mathrm{~km}$ E of Revolcaderos, $11.3 \mathrm{~km} \mathrm{E}$ of Sinaloa border; $8 \mathrm{~km}$ E of Revolcaderos; $3.2 \mathrm{~km}$ E of Revolcaderos, $14.5 \mathrm{~km}$ E of Sinaloa line; $4.8 \mathrm{~km}$ E of Revolcaderos, 12.9 $\mathrm{km}$ E Sinaloa line; $19.4 \mathrm{~km}$ E of Revolcaderos, $27.4 \mathrm{~km}$ E of Sinaloa line; $4.8 \mathrm{~km}$ E of Revolcaderos near highway, 14.5 $\mathrm{km}$ E of Sinaloa line; $8 \mathrm{~km}$ E of Revolcaderos near Highway, $14.5 \mathrm{~km}$ E of Sinaloa line; $48 \mathrm{~km}$ W of Durango: Peromyscus sp. $8 \mathrm{~km} \mathrm{~W}$ of Revolcaderos near Sinaloa border; $3.2 \mathrm{~km}$ E of Revolcaderos, $11.3 \mathrm{~km}$ E of Sinaloa border: Neotoma sp. (Hastriter 2004). Specimens in collections: CMNH, CNC, USNM. ESTADO DE MÉXICO: $1.8 \mathrm{~km}$ N of Barrientos; $3.2 \mathrm{~km}$ $\mathrm{N}$ of Tlalnepantla: Peromyscus gratus (recorded as $P$. truei; Hastriter 2004). Specimens in collections: CMNH, MZFC. Popocatépetl: Microtus mexicanus, P. difficilis, Reithrodon- tomys chrysopsis (Barrera 1968). Cerro Caldera: P. difficilis. $2 \mathrm{~km} \mathrm{~N}$ of Tlalnepantla; $2 \mathrm{~km} \mathrm{~S}$ of Coacalco: P. gratus (recorded as P. truei; Ayala-Barajas et al. 1988). Specimens in collections: MZFC. GUANAJUATO: $8 \mathrm{~km}$ SW of Ibarra: Sigmodon fulviventer (Hastriter 2004). Specimens in collections: CMNH. GUERRERO: 1.6 km NW of Omiltemi: Peromsycus sp. Puerto Chico, Camotla las Bravo: Osgoodomys banderanus. Playa Azul: Peromyscus gratus (recorded as P. truei; Hastriter 2004). Specimens in collections: $\mathrm{CMNH}$, GML. San Miguel Totolapan, Estación Toro Muerto: P. boylii. Santiago Nacaltepec, San Lorenzo Pápalo: P. aztecus (Acosta et al. 2008). Specimens in collections: MZFC. Note: $P$. boylii is not distributed in Guerrero according to Ceballos (2014). HIDALGO: 12.9 km NE of Jacala: Peromyscus hylocetes? [ P. aztecus] (Hastriter 2004). Specimens in collections: $\mathrm{CMNH}$. Note: Author is unsure of identification of $P$. hylocetes; neither $P$. hylocetes nor P. aztecus is distributed in Hidalgo near Jacala according to Ceballos (2014). Between San Juan Hueyapan and Presa San Carlos: Microtus mexicanus, Peromyscus sp. (Ayala-Barajas et al. 1988). Sierra Madre Oriental: Peromyscus sp. (Gutiérrez-Velázquez and Acosta 2004). Specimens in collections: MZFC. JALISCO: Nevado de Colima, near La Joya: Peromyscus hylocetes (Hastriter 2004). Specimens in collections: CMNH. MICHOACÁN: Mt. San Miguel: Microtus mexicanus (Traub 1950). Specimens in collections: FMNH. Tlalpujahua: Peromyscus maniculatus (Ayala-Barajas et al. 1988). Specimens in collections: MZFC. MORELOS: Derrame lávico del Chichinautzin: Neotoma mexicana, Peromyscus sp. (Pérez-Ortiz 1976). Derrame Chichinautzin: N. mexicana, Peromyscus difficilis (Ayala-Barajas et al. 1988). Specimens in collections: MZFC. NUEVO LEÓN: Cerro Potosí: Peromsycus difficilis, P. melanotis (Tipton and Mendez 1968; Hastriter 2004). Specimens in collections: BYU, CMNH, USNM. PUEBLA: Multiple localities: Peromyscus difficilis, P. maniculatus (Acosta and Fernández 2015). $2 \mathrm{~km} \mathrm{~W}$ of Aljojuca; $1 \mathrm{~km} \mathrm{SW}$ of Sn. Pedro Atlixco (AyalaBarajas et al. 1988). Las Esperanza, Las Esperanza: Peromyscus sp. (Acosta et al. 2008). 2 km W Guadalupe Victoria, Mpio. de Guadalupe Victoria: P. maniculatus (Falcón-Ordaz et al. 2012). Specimens in collections: MZFC. $1.6 \mathrm{~km} \mathrm{NE}$ of Alchichica: P. maniculatus (Hastriter 2004). Specimens in collections: UNSM. QUERÉTARO: $2.5 \mathrm{~km}$ NW of Santa Inés and $2.8 \mathrm{~km}$ NW of Santa Inés: Peromyscus furvus. Maguey Verde: P. difficilis (Hastriter 2004). 6.56 km El Lobo, XilitlaJalpan Highway; Pinal de Amoles: P. levipes. $1 \mathrm{~km}$ S of Pinal de Amoles; $2 \mathrm{~km}$ W of Santa Inés: $P$. difficilis. $4 \mathrm{~km} \mathrm{SW}$ of Tequisquiapan: Perognathus flavus (Acosta 2003; Acosta et al. 2008). Landa de Matamoros, $2 \mathrm{~km}$ W of Santa Inés: P. difficilis (Acosta et al. 2008). Specimens in collections: MZFC. SINALOA: $1 \mathrm{~km}$ NE of Santa Lucía; $19.2 \mathrm{~km}$ NE of Santa Lucía: Peromyscus boylii (Hastriter 2004). Specimens in collections: CMNH. $1.6 \mathrm{~km}$ E of Pánuco: Neotoma mexicana (Hastriter 2004). Unknown if specimens are in collections. Note: $P$. boylii is not distributed in Sinaloa according to Ceballos (2014). TLAXCALA: Tlaxco: Peromyscus sp. (AyalaBarajas et al. 1988; Hastriter 2004). Specimens in collec- 
tions: CMNH, MZFC. $10 \mathrm{~km}$ E of Calpulalpan: Peromyscus difficilis (Barrera 1953). Parque Nacional Malinche: Neotomodon alstoni, P. difficilis, P. gratus, P. leucopus, P. levipes, P. maniculatus, P. melanotis, Reithrodontomys fulvescens, R. megalotis (Aguilar-Montiel et al. 2018). Parque Nacional Malinche: Neotomodon alstoni (Acosta and Fernández 2006; Acosta et al. 2008). El Carmen Tequexquitla, El Piñonal: P. difficilis. Huamantla, La Malinche (Caseta \#4): P. gratus. Panotla, San Ambrosio Texantla, Barranca Huehuetitla; Sanctorum de Lázaro Cárdenas, Camino Rural Benito Juárez: Peromyscus sp. (Acosta et al. 2008). Specimens in collections: MZFC. VERACRUZ: Ixhuatlancillo, Rancho La Pala: Peromyscus sp. (Acosta et al. 2008). Specimens in collections: MZFC.

Jellisonia (Jellisonia) breviloba Traub, 1950

ESTADO DE MÉXICO: Zacualpan, 8 km E of Zacualpan: Peromyscus difficilis (Acosta et al. 2008). Specimens in collections: MZFC. OAXACA: Santiago Nacaltepec, San Lorenzo Papálo: P. melanophrys (Acosta et al. 2008). Specimens in collections: MZFC. Note: these specimens were not identified to either of the two subspecies.

\section{Jellisonia (Jellisonia) guerrerensis Morales, 1990}

CHIAPAS: 17 km NW of Teopisca: Peromyscus guatemalensis (Hastriter 2004). Specimens in collections: MZFC. GUANAJUATO: Puerto del Gallo: Oryzomys sp. (Hastriter 2004). Specimens in collections: MZFC. Note: Oryzomys $\mathrm{sp}$. was recorded in the original literature but may represent Handleyomys sp. GUERRERO: $1.6 \mathrm{~km}$ NW of Omiltemi: Peromyscus sp., Reithrodonomys sp. Agua Fria, $22 \mathrm{~km} \mathrm{SW}$ of Yextla; Puerto Chico, Xochipala: Peromyscus megalops. Chilpancingo, $2.5 \mathrm{~km}$ E of Omiltemi; $4 \mathrm{~km} \mathrm{~N}$ of Omiltemi: Megadontomys thomasi, P. megalops. Omiltemi: PeromysCus sp., Reithrodontomys sp. Camotla, Leonardo Bravo: Osgoodomys banderanus (recorded as P. banderanus; Hastriter 2004). Specimens in collections: CMNH, MZFC. Chilpancingo de los Bravo, Omiltemi: M. thomasi, Peromyscus sp. Chilpancingo de los Bravo, $3.5 \mathrm{~km}$ SW of Omiltemi: M. thomasi (Acosta et al. 2008). Specimens in collections: MZFC. OAXACA: Tlahuitoltepec, near Santa María Yachochi: Habromys lepturus, Handleyomys chapmani (recorded as Oryzomys chapmani), Peromyscus aztecus, P. melanocarpus. $7 \mathrm{~m}$ SW of Suchixtepec: Peromyscus sp., Reithrodontomys sp. $16 \mathrm{~km}$ SW of Suchixtepec: Peromyscus sp. Llano las Flores, $87 \mathrm{~km} \mathrm{~N}$ of Oaxaca: Microtus sp. (Hastriter 2004). Specimens in collections: MWH, MZFC. Ixtlán de Juárez, $2.5 \mathrm{~km}$ SE of Santa María Yavesía; Santiago Comaltepec, Tuxtepec-Oaxaca Highway, km 77, Vista Hermosa: P. mexicanus. Santiago Comaltepec, Tuxtepec-Oaxaca Highway, km 79.5, La Esperanza: P. melanocarpus (Acosta et al. 2008). Specimens in collections: MZFC. VERACRUZ: La Joya: Peromyscus sp. (Hastriter 2004). Ixhuatlancillo, Rancho La Pala: Peromyscus sp. (Acosta et al. 2008). Specimens in collections: MZFC.

\section{Jellisonia (Jellisonia) hayesi Traub, 1950}

CIUDAD DE MÉXICO: 5 km E of Sta. Cruz, Meyehualco: Peromyscus difficilis (Ayala-Barajas et al. 1988). Specimens in collections: MZFC. DURANGO: Hidalgo, $4 \mathrm{~km} \mathrm{S-SE} \mathrm{of} \mathrm{La}$ Zarca: Reithrodontomys zacatecae (recorded as Reithrodontomys megalotis zacatecae; Acosta et al. 2008). Specimens in collections: MZFC. ESTADO DE MÉXICO: México City: Microtus mexicanus (Traub 1950). Specimens in collections: FMNH. Zacualpan, Zacualpan-Mamatla Highway, km 7: Peromyscus difficilis (Acosta et al. 2008). Specimens in collections: MZFC. GUERRERO: Omiltemi: Peromyscus sp. (Barrera 1958). Camotla, Mpio. de Chichihualco, Leonardo Bravo: P. gratus (recorded as P. truei; Ayala-Barajas et al. 1988). Specimens in collections: MZFC. $1.6 \mathrm{~km} \mathrm{SW}$ of Omiltemi; 4.8 km E of Omiltemi; Omiltemi: Peromyscus sp. $1.6 \mathrm{~km} \mathrm{NW}$ of Omiltemi: Peromyscus megalops. Camotla, Leonardo Bravo: P. gratus, Heteromys sp. Chilpancingo, Omiltemi: Megadontomys thomasi, P. levipes. Chilchihaulco, Camotla, Leonardo Bravo: P. gratus (Hastriter 2004). Specimens in collections: $\mathrm{CMNH}, \mathrm{MZFC}$. Note: Author is unsure of identification of P. megalops. JALISCO: $1 \mathrm{~km} \mathrm{~S}, 19 \mathrm{~km}$ W of Ciudad Guzmán: Peromyscus sp. Nevado de Colima: Neotoma sp., Peromyscus hylocetes, Peromyscus sp. (Hastriter 2004). Specimens in collections: $\mathrm{CMNH}$. Taxco de Alarcón, Parque Estatal El Huizteco; Tetipac, Huizteco-Tetipac Highway, km 10, Los Llanos: P. aztecus (Acosta et al. 2008). Specimens in collections: MZFC. MICHOACÁN: Monte de San Miguel: Peromyscus hylocetes (Traub 1950; Hastriter 2004). Tancítaro, San Miguel: P. aztecus. $10 \mathrm{~km} \mathrm{~S} \mathrm{(by} \mathrm{road)} \mathrm{of} \mathrm{Pátzcuaro:} \mathrm{Baiomys}$ musculus, Peromyscus sp. (Hastriter 2004). Specimens in collections: FMNH, MWH. Coalcoman de Vázquez Pallares, Pallares, 11.84 km SW of Dos Aguas: P. winkelmanni (Acosta et al. 2008). Specimens in collections: MZFC. Note: P. aztecus is not distributed in Michoacán according to Ceballos (2014). NUEVO LEÓN: Cerro Potosí: Peromyscus difficilis (Tipton and Mendez 1968). Unknown if specimens are in collections. Note: Tipton and Mendez (1968) state that the fleas species is morphologically close to J. h. breviloba. PUEBLA: $1 \mathrm{~km} \mathrm{SW}$ of San Pedro Atlixco: Peromyscus difficilis (Ayala-Barajas et al. 1988). Atzitzintla, Santa Cruz Cuyachapa, Ejido Maguey Cenizo: Microtus mexicanus. La Esperanza: Peromyscus sp. (Acosta et al. 2008). Specimens in collections: MZFC. QUERÉTARO: $13.76 \mathrm{~km}$ SW of Amealco; $6.24 \mathrm{~km}$ W of Amealco; Amealco de Bonfil, 5 km NW of El Batán; $6.56 \mathrm{~km} \mathrm{El}$ Lobo, Xilitla-Jalpan Highway; $1.2 \mathrm{Km} \mathrm{S}$ of Pinal de Amoles; Pinal de Amoles; Landa de Matamoros, $1 \mathrm{~km}$ NW of Santa Inés: Peromyscus sp. $1 \mathrm{~km} \mathrm{NW}$ of Santa Inés; $1.5 \mathrm{~km} \mathrm{NW}$ of Santa Inés; 5 km NW of El Batán; Landa de Matamoros, Xilitla-Jalpan Highway, 6.56 km El Lobo: Peromyscus levipes. Camargo; 11 km NW of Peña Bernal; Toliman, 11 km NW of Peña Bernal: P. pectoralis. Maguey Verde; Peña Bernal; 1 km $S$ of Pinal de Amoles; Cadereyta de Montes, $1 \mathrm{~km}$ SE of Chavarría: P. difficilis. $2.8 \mathrm{~km} \mathrm{NW}$ of Santa Inés: P. furvus. Rancho 99; $5 \mathrm{~km}$ SW of Tequisquiapan: P. gratus. $9 \mathrm{~km}$ SE of Tequisquiapan; 9 km SW of Tequisquiapan: Baiomys taylori. $1 \mathrm{~km}$ SW of Pinal de Amoles: P. difficilis, P. levipes. $1 \mathrm{~km} \mathrm{~W}$ of Santa 
Inés: P. levipes, Peromyscus sp. Landa de Matamoros, 2 km W of Santa Inés: P. difficilis, P. gratus. $2.5 \mathrm{~km}$ NW of Santa Inés: P. furvus, P. levipes, Peromyscus sp. (Acosta 2003; Acosta et al. 2008). Specimens in collections: MZFC. TLAXCALA: El Carmen Tequexquitla, 2.5 km El Carmen: Peromyscus maniculatus (Acosta and Fernández 2015). La Malinche: Neotomodon alstoni, P. difficilis, P. gratus, P. leucopus, P. levipes, $P$. maniculatus, P. melanotis, Reithrodontomys fulvescens (Aguilar-Montiel et al. 2018). Sanctorum de Lázaro Cárdenas, Camino Rural Benito Juárez, La Joya: Peromyscus sp. El Carmen Tequexquitla, El Piñonal: Heteromys irroratus (Acosta et al. 2008). Specimens in collections: MZFC. SIERRA MADRE ORIENTAL: Multiple localities in Hidalgo and Querétaro: Peromyscus difficilis, P. furvus, P. levipes (Gutiérrez-Velázquez and Acosta 2004). Specimens in collections: MZFC.

\section{Jellisonia (Jellisonia) klotsi Traub, 1944}

CIUDAD DE MÉXICO: 42 km N of Cuernavaca: Peromyscus aztecus. 5 km SW of Parres: Neotomodon alstoni, Reithrodontomys sp. (Hastriter 2004). Specimens in collections: MZFC. Parres: Reithrodontomys sp. $5 \mathrm{~km}$ SW of Parres: $N$. alstoni. Km 42 Cuernavaca-México Highway: P. hylocetes (Ayala-Barajas et al. 1988). Specimens in collections: MZFC. El Zarco: Microtus mexicanus (Machado-A. 1960). Unknown if specimens are in collections. ESTADO DE MÉXICO: Lagunas de Zempoala, near Ojotongo: Peromyscus maniculatus, Peromyscus sp. Río Frío, Llano Grande; 4 km W of Río Frío: Neotomodon alstoni (Hastriter 2004). Specimens in collections: CMNH. Slopes of Volcán Popocatépetl: Reithrodontomys megalotis (Barrera 1953). Popocatépetl: Reithrodontomys chrysopsis (Barrera 1968). N. alstoni, R. chrysopsis (Ayala-Barajas et al. 1988). Specimens in collections: MZFC. GUERRERO: Omiltemi: Peromyscus sp. (Barrera 1958). San Miguel Totolapan, Puerto del Gallo; General Heliodoro Castillo, El Iris: Peromyscus megalops. Atoyac de Álvarez, Puerto del Gallo-Paraíso Highway, km 14: Megadontomys thomasi (Acosta et al. 2008). Specimens in collections: MZFC. JALISCO: Nevado de Colima: Microtus mexicanus, Microtus sp., Peromyscus aztecus, P. melanotis, Peromyscus sp., Reithrodontomys sp. (Hastriter 2004). Specimens in collections: $\mathrm{CMNH}, \mathrm{MZFC}$. Nevado de Colima: P. melanotis (Ayala-Barajas et al. 1988). Specimens in collections: MZFC. Note: P. aztecus is not distributed in Jalisco according to Ceballos (2014). MICHOACÁN: Cerro Tancítaro, near Tancítaro: Reithrodontomys chrysopsis (Traub 1944; Barrera 1953; Hastriter 2004). Tancítaro, Mt. Tancítaro: R. chrysopsis, Reithrodontomys sp. (Hastriter 2004). Specimens in collections: BMNH, CMNH, FMNH, USNM. MORELOS: Lagunas de Zempoala, near Ojotongo: Reithrodontomys sp. Lagunas de Zempoala, near Ojo de Agua: Neotomodon sp., Peromyscus difficilis (Hastriter 2004). Specimens in collections: $\mathrm{CMNH}$. Note: Author is unsure of the ID of $P$. difficilis. OAXACA: Ixtlán de Juárez, $4.5 \mathrm{~km}$ SE of Santa María Yavesía: Peromyscus mexicanus. Ixtlán de Juárez, 2.5 km SE of Santa María Yavesía: Oligoryzomys fulvescens, P. aztecus (Acosta et al. 2008). Specimens in collections: MZFC. PUEBLA: Popocatépetl:
Reithrodontomys sp. (Hastriter 2004). Specimens in collections: CMNH, MZFC. QUERÉTARO: Jalpan de Serra, 4 km NE of Ahuacatlán de Guadalupe: Peromyscus pectoralis (Acosta et al. 2008). Specimens in collections: MZFC. TLAXCALA: 10 km NE of Calpulápan: Reithrodontomys sp. (Ayala-Barajas et al. 1988; Hastriter 2004). Specimens in collections: MZFC.

Jellisonia (Jellisonia) maxwelli Hastriter, 2004

NUEVO LEÓN: Chipinque: Peromyscus sp. (Hastriter 2004). Specimens in collections: $\mathrm{CMNH}$.

\section{Jellisonia (Pleochaetoides) amadoi Ponce-Ulloa, 1989}

GUERRERO: El Faisanal, Sierra de Atoyac de Álvarez; La Golondrina, Atoyac: Peromyscus megalops (Hastriter 2004). Specimens in collections: MZFC. QUERÉTARO: $12 \mathrm{~km} \mathrm{NW}$ of Peña Bernal: Peromyscus pectoralis (Acosta 2003). Specimens in collections: MZFC.

Jellisonia (Pleochaetoides) bullisi (Augustson, 1944)

HIDALGO: San Bartolo Tutotepec: Peromyscus sp. (Acosta et al. 2008). Sierra Madre Oriental: Peromyscus sp. (Gutiérrez-Velázquez and Acosta 2004). Specimens in collections: MZFC. NUEVO LEÓN: Cola de Caballo, Barrancas; 4 km SE of Monterrery; Chipinque: Peromyscus sp. (Hastriter 2004). Specimens in collections: MZFC. SAN LUIS POTOSÍ: San Bartolo, Mpio. Río Verde: Peromyscus sp. (Ayala-Barajas et al. 1988). Specimens in collections: MZFC.

\section{Jellisonia (Pleochaetoides) grayi Hubbard, 1958}

GUERRERO: Chilpancingo: Megadontomys thomasi (Hastriter 2004). Specimens in collections: MZFC. OAXACA: Miahuatlán de Porfirio Díaz, 2.3 km de Finca Infiernillo: Heteromys sp. (Acosta et al. 2008). Specimens in collections: MZFC. QUERÉTARO: $1 \mathrm{~km}$ S of Ahuacatlán de Guadalupe; $2 \mathrm{~km}$ S of Ahuacatlán de Guadalupe; $6.56 \mathrm{~km}$ El Lobo, Xilitla-Jalpan Highway; 8 km N of Jalpan; $1 \mathrm{~km}$ W of Santa Inés; $1.5 \mathrm{~km}$ NW of Santa Inés; 2 km W of Santa Inés; $4 \mathrm{~km}$ NW of Santa Inés; Landa de Matamoros, $2 \mathrm{~km}$ W of Santa Inés; Amealco de Bonfil, 5 km NW of El Batán: Peromyscus levipes. Landa de Matamoros, $1.5 \mathrm{~km}$ W of Santa Inés: P. levipes (recorded as P. boylii levipes). Jalpan de Serra, $8 \mathrm{~km} \mathrm{~N}$ of Jalpan; 4 km NE of Ahuacatlán de Guadalupe; 5.1 km SW of Ahuacatlán de Guadalupe: P. pectoralis. Landa de Matamoros, Peñamiller, Camargo; Ezequiel Montes, Peña Bernal; Peñamiller, Maguey Verde: P. difficilis. Landa de Matamoros, 2.8 km NW of Santa Inés: P. furvus. Landa de Matamoros, Xilita-Jalpan Highway, 6.56 km El Lobo: P. boylii. Camargo: P. difficilis, P. pectoralis. Maguey Verde: P. difficilis, P. gratus. Landa de Matamoros, Rancho 99: P. gratus, P. pectoralis. 1 km NW of Santa Inés: P. levipes, P. beatae. $1 \mathrm{~km}$ W of Santa Inés: P. boylii, P. levipes, Peromyscus sp. 2.5 km NW of Santa Inés: P. beatae, $P$. furvus, P. levipes, P. boylii, Peromyscus sp. 13 km NE of Tequisquiapan; 9 km SE of Tequisquiapan: Baiomys taylori (Acosta 2003; Acosta et al. 2008). NW Santa Inés: 
P. boylii (Hastriter 2004). Specimens in collections: MZFC. Note: $P$. beatae is not distributed in Querétaro according to Ceballos (2014). SAN LUIS POTOSÍ: El Salto: Peromyscus boylii, Sigmodon hispidus (Hubbard 1958; Hastriter 2004). Specimens in collections: BMNH. 2 mi NE of El Salto; $8 \mathrm{mi}$ $\mathrm{N}$ of Naranjo: Peromyscus sp. (Ayala-Barajas et al. 1988). Specimens in collections: MZFC. $3 \mathrm{~km}$ NE of El Salto, $15 \mathrm{~km}$ $\mathrm{N}$ of Naranjo: Peromyscus sp. (Hastriter 2004). Specimens in collections: BMNH, CMNH, CNC, REL. Note: S. hispidus is not distributed in San Luis Potosí according to Ceballos (2014). A possible alternative host includes S. leucotis (Ceballos 2014). SIERRA MADRE ORIENTAL: Multiple localities in Hidalgo and Querétaro: Peromyscus difficilis, P. furvus, P. levipes, P. gratus (Gutiérrez-Velázquez and Acosta 2004). Specimens in collections: MZFC.

\section{Jellisonia (Pleochaetoides) ironsi (Eads, 1947)}

CHIAPAS: Comitán and Tninitaria: Baiomys musculus (Hubbard 1958; Hastriter 2004). Specimens in collections: BMNH, USNM. CIUDAD DE MÉXICO: La Venta and Cerro Zacayuca: Baiomys taylori (Barrera 1953; Hubbard 1958, Hastriter 2004). Specimens in collections: $\mathrm{BMNH}, \mathrm{CMNH}$, USNM. Pedregal de San Ángel: B. taylori (Ayala-Barajas et al. 1988). Specimens in collections: MZFC. DURANGO: Peña del Aguila: Peromyscus sp., Reithrodontomys sp. 4.4 km SE of Atotonilco: Baiomys taylori (Hastriter 2004). Specimens in collections: CMNH, REL, USNM. ESTADO DE MÉXICO: Chilpan; Tlalnepantla; $2 \mathrm{~km} \mathrm{~N}$ of Tlalnepantla: Baiomys sp. (Ayala-Barajas et al. 1988). Tlalnepantla: Baiomys sp. (Hatriter 2004). Specimens in collections: MZFC. GUERRERO: Atoyac de Álvarez, Puente de Lugardo: Baiomys musculus. Atoyac de Álvarez, El Faisanal: Heteromys pictus (Acosta et al. 2008). Specimens in collections: MZFC. JALISCO: Zapotlanejo: Baiomys sp., Peromyscus sp. (Hastriter 2004). Specimens in collections: REL, USNM. MORELOS: Tepoztlán: Baoimys sp. (Ayala-Barajas et al. 1988; Hastriter 2004). Specimens in collections: MZFC. NAYARIT: San Cayetano, $8 \mathrm{~km}$ W of Tepic: Peromyscus sp. $1.6 \mathrm{~km}$ W of Tepic: Baiomys sp. (Hastriter 2004). Specimens in collections: $\mathrm{CMNH}, \mathrm{CNC}$, USNM. OAXACA: 4.8 km E of Oaxaca, Benito Juárez National Park, Cerro San Felipe; Monte Albán: Baiomys musculus (Hastriter 2004). Specimens in collections: CMNH, USNM. $15 \mathrm{~km} \mathrm{NW}$ of Miahuatlán: Baiomys sp. (Ayala-Barajas et al. 1988). Specimens in collections: MZFC. PUEBLA: Matamoros: Baiomys sp. (Hastriter 2004). Specimens in collections: MWH. San Juan Atenco Cerro Caldera: Baiomys taylori (Acosta et al. 2008). Specimens in collections: MZFC. QUERÉTARO: Amealco de Bonfil, $5 \mathrm{~km}$ NW of Batán; Landa de Matamoros, $1 \mathrm{~km} \mathrm{NW}$ of Santa Inés: Peromyscus levipes. Ezequiel Montes, Peña Bernal: P. difficilis. Colón, 4 km NW of Colón: P. pectoralis. Landa de Matamoros, Rancho 99: P. gratus. Tequisquiapan, $5 \mathrm{~km}$ SW of Tequisquiapan: P. gratus, P. pectoralis. Tequisquiapan, $9 \mathrm{~km}$ SE of Tequisquiapan: Baiomys taylori (Acosta et al. 2008). $4 \mathrm{~km} \mathrm{NW}$ of Colón; $5 \mathrm{~km} \mathrm{SW}$ of Tequisquiapan: P. pectoralis. $8 \mathrm{~km} \mathrm{~N}$ of Jalpan: B. taylori, P. gratus. $9 \mathrm{~km} \mathrm{SE}$ of Tequisquiapan: B. taylori (Acosta 2003). Specimens in collections: MZFC. SAN LUIS POTOSÍ: El Salto, $11.2 \mathrm{~km} \mathrm{~N}$ of Naranjo; 3.2 km E of El Salto, 14.5 km N of Naranjo: Baiomys taylori (Hastriter 2004). Specimens in collections: $\mathrm{CMNH}$, CNC. SONORA: Los Fresnos: Baiomys taylori, Peromyscus fraterculus (Zapata-Valdés et al. 2018). No specimens in collections.

\section{Jellisonia (Pleochaetoides) mexicana Ponce-Ulloa, 1989}

DURANGO: Revolcaderos, $1.6 \mathrm{~km}$ SW of Revolcaderos: Peromyscus sp. (Hastriter 2004). Specimens in collections: CMNH. GUERRERO: Nueva Delhi: Neotoma mexicana. 8 km E of Omiltemi: Peromyscus sp. (Hastriter 2004). Specimens in collections: CMNH, MZFC. Atoyac de Álvarez, Nueva Delhi: Neotoma mexicana (Acosta et al. 2008). Specimens in collections: MZFC. JALISCO: $9.7 \mathrm{~km}$ W of San Marcos: Heteromys pictus (Hastriter 2004). Specimens in collections: CMNH. NAYARIT: $5.5 \mathrm{~km}$ E of San Blas (Hotel Bucanaro): Peromyscus fraterculus, Heteromys pictus (Hastriter 2004). Specimens in collections: CMNH. SINALOA: $1 \mathrm{~km}$ NE of Santa Lucia: Peromyscus spicilegus, Reithrodontomys fulvescens, Heteromys pictus. $5 \mathrm{~km}$ NE of Santa Lucia: P. spicilegus. 1.9 km NE of Santa Lucía: H. pictus. 1.6 km E of Pánuco: Neotoma mexicana (Hastriter 2004). Specimens in collections: CMNH. SONORA: 12.9 km S-SE of Álamos on Río Cuchujaqui: Heteromys pictus (Hastriter 2004). Specimens in collections: $\mathrm{CMNH}$.

Jellisonia (Pleochaetoides) wisemani Eads, 1951

CHIAPAS: Volcán Kagchiná, $3.5 \mathrm{~km} \mathrm{~N}$ of las Margaritas; Cueva Santa Rosa, 2 km N, 3 km W of Las Margaritas; Cueva Llano Redondo, $3 \mathrm{~km} \mathrm{~N}$ of las Margaritas: Neotoma mexicana. Pan American Highway over Río San Gregorio, $32 \mathrm{~km}$ from Guatemalan border: Neotoma ferruginea (Hastriter 2004). Specimens in collections: CMNH. CIUDAD DE MÉXICO: Pedregal de San Ángel: Peromyscus gratus (recorded as P. truei; Barrera 1953). Cuajimalpa de Morelos, $1 \mathrm{~km}$ del Potrillo, Parque Nacional Desierto de los Leones: P. difficilis (Acosta et al. 2008). Specimens in collections: MZFC. DURANGO: $4 \mathrm{~km} \mathrm{S-SE} \mathrm{of} \mathrm{la} \mathrm{Zarca,} \mathrm{Mpio:}$ Reithrodontomys megalotis (Acosta et al. 2006). Specimens in collections: MZFC. Peña de Águila: Peromyscus sp. (Hastriter 2004). Specimens in collections: CMNH. ESTADO DE MÉXICO: Cueva de la Estrella Tonatico: Neotoma mexicana (recorded as N. torquata; Ayala-Barajas et al. 1988). Specimens in collections: MZFC. GUERRERO: La Joya Cacahuamilpa: Peromyscus sp. nest (Ayala-Barajas et al. 1988). Specimens in collections: MZFC. $4.8 \mathrm{~km} \mathrm{E}$ of Omiltemi; $8 \mathrm{~km} \mathrm{E}$ of Omiltemi; $16 \mathrm{~km} \mathrm{~S}$ of Taxco (near Telcalpuco): Peromyscus sp. (Hastriter 2004). Specimens in collections: $\mathrm{CMNH}$. HIDALGO:Tenango de Doria, El Potrero: Megadontomys sp., Peromyscus furvus (Acosta et al. 2008). Specimens in collections: MZFC. JALISCO: $4.8 \mathrm{~km}$ N of Guadalajara: Peromyscus melanophrys (Eads 1951; Hastriter 2004). Specimens in collections: KU, USNM. Huastaco: P. levipes (recorded as P. boylii levipes; Ayala-Barajas et al. 1988). Specimens in collections: 
MZFC. Calderon Hacienda, 13 km E of Zapotlanejo, 39 km S of Guadalajara: Baiomys sp., Peromyscus sp. Zapotlanejo, 39 km S of Guadalajara: Peromyscus sp., Reithrodontomys sp. (Hastriter 2004). Specimens in collections: CMNH. Note: P. levipes is not distributed in Jalisco according to Ceballos (2014). MICHOACÁN: 3 km SW of Turundeo: Peromyscus sp. (Ayala-Barajas et al. 1988). Specimens in collections: MZFC. $18 \mathrm{~km}$ W of Jiquilpan: Peromyscus boylii. Cerro Guyman: Peromyscus sp. 4.8 km NE of Pátzcuaro: Sigmodon sp. $4.8 \mathrm{~km}$ SW of Turundeo: Peromyscus sp. (Hastriter 2004). Specimens in collections: BMNH, CMNH, CNC, MZFC. $13 \mathrm{~km} \mathrm{SW}$ of Jacona: Reithrodontomys sp. (AyalaBarajas et al. 1988; Hastriter 2004). Specimens in collections: MZFC. Note: P. boylii is not distributed in Michoacán according to Ceballos (2014). MORELOS: Tepoztlán: Peromyscus aztecus, Peromyscus sp. (Hastriter 2004). Specimens in collections: MZFC. Derrame de Chichinautzin: P. difficilis, Neotoma mexicana (Pérez-Ortiz 1976; Ayala-Barajas et al. 1988; Hastriter 2004). Specimens in collections: MZFC. Tepoztlán: P. hylocetes, Peromyscus sp. (Ayala-Barajas et al. 1988). Tepalcingo, Subestacion El Limón: Peromyscus sp. (Acosta et al. 2008). Specimens in collections: MZFC. Note: $P$. aztecus is not distributed in Morelos according to Ceballos (2014). OAXACA: Huajuapan de León: Peromyscus sp. 10 km SE of Miahuatlán: Peromyscus melanophrys. Monte Albán: P. gratus, P. maniculatus (Hastriter 2004). Specimens in collections: CMNH, MZFC. $10 \mathrm{~km} \mathrm{SE}$ of Miahuatlán: $P$. melanophrys, P. gratus (recorded as P. truei; Ayala-Barajas et al. 1988). Specimens in collections: MZFC. PUEBLA: 6 km E of Totimihuacan: Peromyscus boylii. Villa Juárez: Peromyscus sp. (Ayala-Barajas et al. 1988). Multiple localities: $P$. furvus (Acosta and Fernández 2015). Specimens in collections: MZFC. $5.6 \mathrm{~km} \mathrm{W-NW} \mathrm{of} \mathrm{Zapoltitic:} \mathrm{Heteromys} \mathrm{pictus.}$ Villa Juárez, Xicotepec: Peromyscus sp. (Hastriter 2004). Specimens in collections: CMNH, MZFC. Note: P. boylii is not distributed in Puebla according to Ceballos (2014). QUERÉTARO: $3.7 \mathrm{~km}$ SW of Ahuacatlán de Guadalupe; Xilitla, 2 km NE of Jalpan-Xilitla Highway, km 192.3; 5 km NW of El Batán; 1 km NW of Santa Inés: Peromyscus levipes. Landa de Matamoros, 2.5 km NW of Santa Inés: P. beatae. $5 \mathrm{~km}$ SE of Tequisquiapan: P. pectoralis. Tequisquiapan, 9 km SE of Tequisquiapan; Pinal de Amoles, Ahuacatlán de Guadalupe: Baiomys taylori. Amealco de Bonfil, GalindoAmealco Highway, km 11: B. taylori, P. levipes. Tolimán, 11 km NW of Peña Bernal: P. melanophrys, P. pectoralis. Peña Bernal: Peromyscus difficilis, Peromyscus sp. $14 \mathrm{~km} \mathrm{SW}$ of Peña Bernal: Heteromys irroratus, Sigmodon hispidus. 11 km SW of Peña Bernal: P. difficilis, P. melanophrys, P. pectoralis. $5 \mathrm{~km} \mathrm{SW}$ of Tequisquiapan: P. gratus, P. pectoralis, Peromyscus sp. Tolimán, 12 km NW of Peña Bernal: $P$. difficilis, P. melanophrys, P. pectoralis (Acosta 2003; Acosta et al. 2008). Specimens in collections: MZFC. Note: P. beatae and S. hispidus are not distributed in Querétaro according to Ceballos (2014). A possible alternative host includes $S$. leucotis (Ceballos 2014). VERACRUZ: Texolo: Peromyscus sp. (Traub and Johnson 1952b). Specimens in collection:
AMNH. El Coderio, Jalapa; Texolo: Peromyscus sp. $4.8 \mathrm{mi} \mathrm{NE}$ of Las Minas: Peromyscus mexicanus (Hastriter 2004). Specimens in collections: AMNH, CMNH, MZFC. Xico, Texolo: P. mexicanus. Ixhuatlancillo, Rancho La Pala: Peromyscus sp. (Acosta et al. 2008). El Cedeño, Jalapa: Peromyscus sp. (Ayala-Barajas et al. 1988). Specimens in collections: MZFC. SIERRA MADRE ORIENTAL: Multiple localities in Coahuila, Guanajuato, Hidalgo, Nuevo León, Puebla, Querétaro, Tamaulipas, and Veracruz: Peromyscus maniculatus, Peromyscus sp., Dipodomys phillipsii (Gutiérrez-Velázquez and Acosta 2004). Specimens in collections: MZFC. Note: D. phillipsii is not distributed in Coahuila, Nuevo León, or Tamaulipas according to Ceballos (2014). Dipodomys phillipsii in Guanajuato and Querétaro likely represent $D$. ornatus (Fernández et al. 2012).

\section{Jellisonia sp.}

CHIAPAS: Finca la Esperanza: Peromyscus guatemalensis (Ayala-Barajas et al. 1988). Specimens in collections: MZFC. CIUDAD DE MÉXICO: Cuajimalpa de Morelos, Cañada San Miguel, Presa, Parque Nacional Desierto de los Leones: Reithrodontomys sp. (Acosta et al. 2008). Specimens in collections: MZFC. GUERRERO: Agua Fría: P. megalops. Omiltemi: Peromyscus sp., Reithrodontomys sp. Puerto Chico, Xochipala: Megadontomys thomasi, P. megalops (Ayala-Barajas et al. 1988). Atoyac de Álvarez, El Faisanal: Peromyscus megalops (Acosta et al. 2008). Specimens in collections: MZFC. PUEBLA: $1 \mathrm{~km}$ SW of San Pedro Atlixco: Peromyscus sp. (Ayala-Barajas et al. 1988). La Esperanza: Peromyscus sp. (Acosta et al. 2008). Specimens in collections: MZFC. QUERÉTARO: Jellisonia sp. A: 2.8 km NW of Santa Inés: Peromyscus furvus. $1 \mathrm{~km}$ W of Santa Inés; 1 km NW of Santa Inés; $1.2 \mathrm{~km}$ S of Pinal de Amoles; $6.56 \mathrm{~km}$ El Lobo, Xilitla-Jalpan Highway: P. levipes. $1.2 \mathrm{~km}$ SW of Pinal de Amoles; $1 \mathrm{~km} \mathrm{~S}$ of Pinal de Amoles: P. difficilis, P. levipes. Jellisonia sp. B: $2 \mathrm{~km} \mathrm{~S}$ of Ahuacatlán de Guadalupe; 6.56 km El Lobo, Xilitla-Jalpan Highway; $1.2 \mathrm{~km}$ S of Pinal de Amoles; $1 \mathrm{~km}$ W of Santa Inés; $1.5 \mathrm{~km}$ W of Santa Inés: P. levipes. Maguey Verde: P. difficilis. $2.8 \mathrm{~km} \mathrm{~W}$ of Santa Inés: P. furvus. $1 \mathrm{~km} \mathrm{~S}$ of Ahuacatlán de Guadalupe: P. levipes, P. pectoralis. Camargo: P. difficilis, P. pectoralis. Jellisonia sp. C: Camargo; 9 km Amealco-La Estancia Highway; $1 \mathrm{~km}$ S of Pinal de Amoles; $1 \mathrm{~km} \mathrm{~S}$ of Pinal de Amoles: P. difficilis. $1.2 \mathrm{~km} \mathrm{~S}$ of Pinal de Amoles; $1 \mathrm{~km} \mathrm{~W}$ of Santa Inés: P. levipes. Maguey Verde: $P$. gratus. $1 \mathrm{~km}$ SW of Pinal de Amoles: P. difficilis, P. levipes. Jellisonia sp. D: Maguey Verde: P. difficilis. Jellisonia sp. E: 9 km Amealco-La Estancia Highway: P. difficilis (Acosta 2003). Specimens in collections: MZFC. $2 \mathrm{~km}$ S of Ahuacatlán de Guadalupe; 11 km GalindoAmealco Highway: Baiomys taylori (Acosta 2003). Specimens in collections: MZFC. VERACRUZ: Zongolica: Peromyscus sp. (Ayala-Barajas et al. 1988). Specimens in collections: MZFC.

\section{Kohlsia cora Traub, 1950}

OAXACA: Ixtlán de Juáez, 6.5 km E-SE of Santa María Yavesía: Peromyscus melanocarpus. Miahuatlán de Por- 
firio Díaz, $1.2 \mathrm{~km}$ de Finca Brasil: Peromyscus sp. (Acosta et al. 2008). Specimens in collections: MZFC. QUERÉTARO: La Florida: Peromyscus gratus (Acosta 2003). Cadereyta de Montes, La Florida: P. gratus (Acosta et al. 2008). Specimens in collections: MZFC. Note from Traub et al. (1983): Kohlsia cora was previously only known from Puebla, Nuevo León, Chiapas and the mountains in southern Guatemala in a rodent nest.

\section{Kohlsia fournieri Vargas, 1951}

CHIAPAS: Comitán and La Esperanza: Peromyscus guatemalensis (Vargas 1951a; Ayala-Barajas et al. 1988). Specimens in collections: MZFC. OAXACA: Ixtlán de Juárez, 2.5 km SE of Santa María Yavesía: Peromyscus aztecus (Acosta et al. 2008). Specimens in collections: MZFC.

\section{Kohlsia keenani Tipton and Méndez, 1961}

CHIAPAS: Angel Albino Corzo, Reserva El Triunfo: Handleyomys rhabdops (recorded as Orzyomys rhabdops angusticeps; Acosta et al. 2008). Specimens in collections: MZFC. OAXACA: San Juan Atepec, Tuxtepec-Oaxaca Highway, km 91, Camino a San Isidro: Peromyscus melanocarpus (Acosta et al. 2008). Specimens in collections: MZFC.

\section{Kohlsia linni Hubbard, 1958}

CHIAPAS: Pueblo Nuevo: Neotoma mexicana, Peromyscus boylii (Hubbard 1958). Specimens in collections: BMNH. Note: P. boylii is not distributed in Chiapas according to Ceballos (2014).

\section{Kohlsia martini Holland, 1971}

CHIAPAS: km 145 Highway 175 de Oaxaca, approximately $90 \mathrm{mi} \mathrm{N}$ of Oaxaca: Oryzomys sp. (Holland 1971). Specimens in collections: CNC. Note: Oryzomys sp. was recorded in the original literature but may represent Handleyomys sp. OAXACA: Ixtlán de Juárez, 6.5 km E-SE of Santa María Yavesía; San Juan Atepec, Tuxtepec-Oaxaca Highway, km 91, on the road to San Isidro; Santiago Comaltepec, Tuxtepec-Oaxaca Highway, km 79.5, La Esperanza; Santiago Comaltepec, Tuxtepec-Oaxaca Highway, km 87, El Suspiro: Peromyscus melanocarpus (Acosta et al. 2008). Specimens in collections: MZFC. QUERÉTARO: Peñamiller, Camargo: Peromyscus difficilis (Acosta et al. 2008). Specimens in collections: MZFC.

\section{Kohlsia ortizi (Vargas, 1951)}

CHIAPAS: Comitán: Peromyscus sp. (Vargas 1951b; Hastriter 2004). 6 mi NW of Teopisca: Peromyscus guatemalensis (Hastriter 2004). Specimens in collections: BMNH, IBUNAM, INDRE. GUERRERO: Chilpancingo de los Bravo, $0.5 \mathrm{~km}$ W of Omiltemi: Peromyscus aztecus. Atoyac de Álvarez, El Molote: Peromyscus sp. (Acosta et al. 2008). Specimens in collections: MZFC. OAXACA: Ixtlán de Juárez, 4 km SE of
Santa María Yavesía: Peromyscus aztecus, P. mexicanus. Miahuatlán de Porfirio Díaz, 2.3 km de Finca Infiernillo: Heteromys sp. (Acosta et al. 2008). Specimens in collections: MZFC.

\section{Kohlsia pelaezi Barrera, 1956}

GUERRERO: Omiltemi: Peromyscus sp. (Barrera 1956; Barrera 1958; Ayala-Barajas et al. 1988). Agua Fría, Yextla: Peromyscus megalops. Camotla: Osgoodomys banderanus (recorded as Peromyscus banderanus vicinior). $1 \mathrm{mi} \mathrm{SW}$ of Omiltemi: Peromyscus sp. (Ayala-Barajas et al. 1988). Atoyac de Álvarez, Nueva Delhi; Tlacotepec, 7 km Puerto del Gallo-El Paraíso Highway; Chilpancingo de los Bravo, Omiltemi; San Miguel Totolapan, Estación Toro Muerto; Atoyac de Álvarez, La Golondrina: P. megalops. General Heliodoro Castillo, El Iris: Megadontomys thomasi. Atoyac de Álvarez, El Molote: Peromyscus sp. San Luis Acatlán, Yerba-Santa: Megadontomys sp., Peromyscus sp. Atoyac de Álvarez, El Faisanal: Handleyomys alfaroi (recorded as Oryzomys alfaroi), P. megalops. Atoyac de Álvarez, $3 \mathrm{~km} \mathrm{~S}$ of Puerto del Gallo: M. thomasi, H. alfaroi (recorded as $O$. alfaroi). Atoyac de Álvarez, Los Retrocesos: Neotoma mexicana, H. alfaroi (recorded as O. alfaroi), P. megalops, Heteromys pictus (Acosta et al. 2008). Specimens in collections: MZFC. Note: Author was unsure of the identification of Osgoodomys banderanus. QUERÉTARO: La Florida: Peromyscus gratus, P. pectoralis. $4 \mathrm{~km}$ SW of Tequisquiapan: Perognathus flavus (Acosta 2003). Cadereyta de Montes, La Florida: P. gratus. Peñamiller, Camargo: P. difficilis. Pinal de Amoles, $1 \mathrm{~km} S$ of Ahuacatlán de Guadalupe; Pinal de Amoles, $1 \mathrm{~km} S$ of Pinal de Amoles: $P$. levipes (recorded as $P$. boylii levipes). Tequisquiapan, $4 \mathrm{~km} \mathrm{SW}$ of Tequisquiapan: Perognathus flavus. Tolimán, $12 \mathrm{~km}$ NW of Peña Bernal: $P$. pectoralis (Acosta et al. 2008). Specimens in collections: MZFC. VERACRUZ: Xico, Texolo: Peromyscus mexicanus (Acosta et al. 2008). Sierra Madre Oriental: Peromyscus sp. (Gutiérrez-Velázquez and Acosta 2004). Specimens in collections: MZFC.

Kohlsia whartoni Traub and Johnson, 1952

CHIAPAS: Pueblo Nuevo: Neotoma mexicana, Peromyscus boylii (Hubbard 1958). Specimens are in collections: Unknown, possibly BMNH. Note: P. boylii is not distributed in Chiapas according to Ceballos (2014). GUERRERO: Atoyac de Álvarez, El Molote: Peromyscus sp. (Acosta et al. 2008). Specimens in collections: MZFC. HIDALGO:Tlanchinol: Peromyscus aztecus (Salceda-Sánchez and Hastriter 2006). Specimens in collections: CAIM, InDRE. OAXACA: Ixtlán de Juárez, $1.5 \mathrm{~km}$ SE of Santa María Yavesía: Peromyscus aztecus. Ixtlán de Juárez, 2.5 km SE of Santa María Yavesía: P. aztecus, P. gratus (recorded as P. truei), Peromyscus sp. Miahuatlán de Porfirio Díaz, $1.2 \mathrm{~km}$ de Finca Brasil; Miahuatlán de Porfirio Díaz, 2.3 km de Finca La Gloria: Peromyscus sp. Miahuatlán de Porfirio Díaz, $2.3 \mathrm{~km}$ de Finca Brasil: Peromyscus sp., Heteromys sp. (Acosta et al. 2008). Specimens in collections: MZFC. PUEBLA: Multiple 
localities: Peromyscus levipes (Acosta and Fernández 2015). Xicotepec, El Salto: Peromyscus sp. (Acosta et al. 2008). Specimens in collections: MZFC. VERACRUZ: Texolo: Peromyscus sp. (Traub and Johnson 1952a). Specimens in collections: FMNH. Catemaco: Peromyscus mexicanus. 1/2 mi NE of Las Minas (approximately $16 \mathrm{mi}$ NE of Perote): Peromyscus sp. (Ayala-Barajas et al. 1988). Xico, Texolo: P. mexicanus (Acosta et al. 2008). Sierra Madre Oriental: Peromyscus sp. (Gutiérrez-Velázquez and Acosta 2004). Specimens in collections: MZFC.

\section{Kohlsia zyanya Acosta et al., 2009}

OAXACA: Sierra de Juárez km 87 Tuxtepec-Oaxaca Highway: Peromyscus melanocarpus. Sierra de Juárez km 91 Tuxtepec-Oaxaca Highway; San Juan Atepec, km 91 TuxtepecOaxaca Highway: P. melanocarpus, P. mexicanus. Sierra de Juárez, La Esperanza km 79: P. melanocarpus, P. mexicanus, Peromyscus sp. (Acosta et al. 2009). Specimens in collections: CAIM, Indre, MZFC.

\section{Kohlsia sp.}

CHIAPAS: Raundales: Peromyscus mexicanus (Ayala-Barajas et al. 1988). Specimens in collections: MZFC. ESTADO DE MÉXICO: Slopes of Volcán Popocatépetl: Peromyscus melanotis (Barrera 1953). Specimens in collections: MZFC. OAXACA: $10 \mathrm{~km}$ S of San Juan Lachao: Oryzomys sp. (AyalaBarajas et al. 1988). Miahuatlán de Porfirio Díaz, $1.2 \mathrm{~km}$ de Finca Brasil; Miahuatlán de Porfirio Díaz, 2.3 km de Finca Brasil: Peromyscus sp. (Acosta et al. 2008). Specimens in collections: MZFC. Note: Oryzomys sp. was recorded in the original literature but may represent Handleyomys sp.

\section{Malaraeus eremicus (Baker, 1904)}

SONORA: La Mesa: Peromyscus maniculatus. Los Fresnos: P. fraterculus (Zapata-Valdés et al. 2018). No specimens in collections.

\section{Nosopsyllus fasciatus (Bosc, 1800)}

CIUDAD DE MÉXICO: La Venta: Peromyscus maniculatus (Barrera 1953, Ayala-Barajas et al. 1988). Specimens in collections: MZFC.

\section{Opisodasys hollandi Traub, 1947}

GUERRERO: 35 km SW of Xochipala: Peromyscus boylii evides (Ayala-Barajas et al. 1988). Specimens in collections: MZFC. Note: P. boylii is not distributed in Guerrero according to Ceballos (2014).

\section{Opisodasys robustus (Jordan, 1925)}

DURANGO: Hidalgo, 4 km S-SE of la Zarca: Peromyscus pectoralis, Perognathus flavus (Acosta et al. 2006; 2008). Specimens in collections: MZFC. Opisodasys sp. QUERÉ-
TARO: La Florida: Peromyscus gratus (Acosta 2003). Specimens in collections: MZFC.

\section{Orchopeas fulleri Traub, 1950}

HIDALGO: Tlanchinol: Peromyscus furvus (Salceda-Sánchez and Hastriter 2006). Specimens in collections: CAIM, InDRE.

\section{Orchopeas leucopus (Baker, 1904)}

BAJA CALIFORNIA: Rancho El Metate, S Juan de Dios, Matomi: Peromyscus sp. (Ayala-Barajas et al. 1988). Specimens in collections: MZFC. CHIAPAS: Tuxtla Gutiérrez: Peromyscus mexicanus (Barrera 1955a; 1955b). Tuxtla Gutiérrez: Peromyscus sp. Sta. Inés: Baiomys sp., Sigmodon hispidus (Ayala-Barajas et al. 1988). Specimens in collections: MZFC. Note: S. hispidus is not distributed in Chiapas according to Ceballos (2014). Possible alternative hosts include S. hirsutus, S. mascotensis, S. toltecus, or S. zanjonensis (Ceballos 2014). CHIHUAHUA: Janos Biosphere Reserve: Onychomys leucogaster, Peromyscus leucopus, P. maniculatus (Fernández-González et al. 2016). No specimens in collections. GUANAJUATO: La Noria, 3 km E of S. Diego, La Unión: Peromyscus sp. (Ayala-Barajas et al. 1988). Specimens in collections: MZFC. HIDALGO: Tlanchinol: Peromyscus mexicanus (Salceda-Sánchez and Hastriter 2006). Specimens in collections: CAIM, InDRE. NUEVO LEÓN: Rancho 14 de Marzo, de China, Monterrey: Onychomys sp. (Ayala-Barajas et al. 1988). Specimens in collections: MZFC. QUERÉTARO: Cadereyta de Montes, La Florida: Peromyscus gratus (Acosta et al. 2008). Specimens in collections: MZFC. SAN LUIS POTOSÍ: $5 \mathrm{~km} \mathrm{SW}$ of Núñez: Neotoma sp., Peromyscus sp. (Ayala-Barajas et al. 1988). Specimens in collections: MZFC. SONORA: Los Fresnos: Peromyscus fraterculus, Sigmodon fulviventer (ZapataValdés et al. 2018). No specimens in collections.

\section{Orchopeas intermedius Hubbard, 1943}

COAHUILA: Sabinas: Neotoma micropus (Salceda-Sánchez and Hastriter 2006). Specimens in collections: CAIM, InDRE.

\section{Orchopeas neotomae Augustson, 1943}

ESTADO DE MÉXICO: Popocatépetl: Neotoma mexicana, Neotoma sp. (Barrera 1968; Ayala-Barajas et al. 1988). Specimens in collections: MZFC. MORELOS: Lagunas de Zempoala: Neotoma mexicana (recorded as N. torquata; Ayala-Barajas et al. 1988). Specimens in collections: MZFC. NUEVO LEÓN: Cerro Potosí: Neotoma leucodon (recorded as N. albigula; Tipton and Mendez 1968). Unknown if specimens are in collections. Note: Neotoma albigula was recognized as the original host. However, according to Bradley and Mauldin (2016), N. albigula from the eastern part of Mexico is now recognized as N. leucodon. TLAXCALA: La Malinche: Neotoma mexicana (Aguilar-Montiel et al. 2018). Specimens in collections: MZFC. 
Orchopeas schisintus (Jordan, 1929)

SONORA: Hermosillo: Neotoma albigula, Peromyscus fraterculus, Dipodomys merriami (Vargas 1960). Unknown if specimens are in collections. Rcho. Noche Buena, $30 \mathrm{~km}$ NNW Guaymas: Neotoma sp. (Ayala-Barajas et al. 1988). Specimens in collections: MZFC.

\section{Orchopeas sexdentatus (Baker, 1904)}

CHIHUAHUA: Janos Biosphere Reserve: Neotoma albigula (Fernández-González et al. 2016). No specimens in collections. MORELOS: Lagunas de Zempoala, $1 \mathrm{~km}$ NE de la Laguna: Neotoma mexicana (Barrera 1954a). Specimens in collections: MZFC.

\section{Orchopeas sexdentatus ssp.}

MORELOS: Lagunas de Zempoala: Neotoma mexicana (Barrera 1954a). Specimens in collections: MZFC.

\section{Orchopeas sp.}

CHIAPAS: Tuxtla Gtz.: Peromyscus sp. (Ayala-Barajas et al. 1988). Specimens in collections: MZFC.

\section{Oropsylla (Opisocrotis) hirsuta (Baker, 1895)}

SONORA: Los Fresnos: Chaetodipus hispidus (Zapata-Valdés et al. 2018). No specimens in collections.

\section{Pleochaetis exilis (Jordan, 1937)}

CHIHUAHUA: Janos Biosphere Reserve: Onychomys arenicola, O. leucogaster, Peromyscus maniculatus (Fernández-González et al. 2016). No specimens in collections. SONORA: La Mesa: Onychomys torridus (Zapata-Valdés et al. 2018). No specimens in collections.

\section{Pleochaetis mundus (Jordan and Rothschild, 1922)}

CIUDAD DE MÉXICO: Lomas de Chapultepec: Peromyscus melanotis (Dampf 1942). Specimens in collections: Collection of the author, NHM, NMNH. Km 3.5 México-Xochimilco Highway: Microtus mexicanus, Peromyscus sp. (MachadoA. 1960). Unknown if specimens are in collections. $5 \mathrm{~km}$ Sta. Cruz Meyehualco: $P$. difficilis. San Andrés Tetepilco: $P$. maniculatus (Ayala-Barajas et al. 1988). Specimens in collections: MZFC. ESTADO DE MÉXICO: Popocatépetl: Microtus mexicanus, Peromyscus difficilis, P. maniculatus (Barrera 1968). Amecameca; Popo Park: Peromyscus sp. Cerro de la Caldera: Peromyscus difficilis. Popocatépetl, 5 km E Sn. Pedro Nexapa: Peromyscus maniculatus. Sn. Cayetano: Reithrodontomys sp. (Ayala-Barajas et al. 1988). Specimens in collections: MZFC. HIDALGO: Arroyo Piedras Negras: Reithrodontomys megalotis (Barrera 1953; Ayala-Barajas et al. 1988). Xoxafi: Peromyscus difficilis (Ayala-Barajas et al. 1988). Specimens in collections: MZFC. JALISCO: La Barca: Sigmodon hispidus (Dampf 1942). Specimens in collections:
Collection of the author, NHM, NMNH. Huastaco: Peromyscus levipes (recorded as P. boylii levipes). $7 \mathrm{~km}$ SE of Tonalá: Peromyscus sp. (Ayala-Barajas et al. 1988). Specimens in collections: MZFC. Note: S. hispidus is not distributed in Jalisco according to Ceballos (2014). Possible alternative hosts include S. alleni, S. fulviventer, and S. mascotensis (Ceballos 2014). MICHOACÁN: 3 km SW of Sn. Fco. Tlalpujahua: Peromyscus maniculatus (Ayala-Barajas et al. 1988). Specimens in collections: MZFC. Tancítaro: Peromyscus hylocetes, Reithrodontomys chrysopsis (Traub 1950). Unknown if specimens are in collections. MORELOS: Zempoala: Peromyscus hylocetes (Ayala-Barajas et al. 1988). Specimens in collections: MZFC. PUEBLA: Aljojuca; $2 \mathrm{~km}$ W of Atenco de Aljojuca, road to San Salavador el Seco; $1 \mathrm{~km}$ SW of San Pedro Atlixco: Peromyscus sp. 1 mi NE of Alchichica: Peromyscus maniculatus (Ayala-Barajas et al. 1988). $2 \mathrm{~km} \mathrm{~W}$ Guadalupe Victoria, Mpio. de Guadalupe Victoria: P. maniculatus. $1 \mathrm{~km}$ S Santa Cruz Coyotepec, Mpio. de San Salvador El Seco: $P$. difficilis, P. maniculatus (Falcón-Ordaz et al. 2012). Specimens in collections: MZFC. QUERÉTARO: $2 \mathrm{~km}$ NW of Peña Bernal; Landa de Matamoros, $1 \mathrm{~km}$ W of Santa Inés: Peromyscus melanophrys. Amealco de Bonfil, 4 km Amealco: P. levipes. $9 \mathrm{~km} \mathrm{~N}$ Amealco Highway; 9 km Amealco-La Estancia Highway; 8 km N Jalpan; Peñamiller, 0.5 km NW Camargo: $P$. difficilis. Amealco de Bonfil, $8.6 \mathrm{mi}$ SW Amealco: P. boylii. 4 km NW Colón; Peñamiller; 5 km SE Tequisquiapan: P. pectoralis. Tequisquiapan, $9 \mathrm{~km}$ SE Tequisquiapan: Baiomys taylori. Ezequiel Montes, 5 km W Peña Bernal: Sigmodon sp. 14 km SW Peña Bernal: Heteromys irroratus. Colón, 14 km SW Peña Bernal: Heteromys sp. Amealco de Bonfil, 5 km NW El Batán; Cadereyta de Montes, 6 km S-SE San Joaquín: P. difficilis, P. levipes. $11 \mathrm{~km}$ Galindo-Amealco Highway: B. taylori, P. levipes. 5 km SW Tequisquiapan: Peromyscus sp., P. gratus, P. pectoralis. Peña Bernal: Peromyscus sp., P. levipes, P. difficilis. Camargo: P. difficilis, P. gratus, P. pectoralis. Tolimán, 11 km NW of Peña Bernal: P. difficilis, P. melanophrys, P. pectoralis. Peñamiller, Camargo: $P$. difficilis; $P$. gratus (recorded as $P$. truei gratus), P. pectoralis. $13.76 \mathrm{~km} \mathrm{SW}$ of Amealco; $4 \mathrm{~km} \mathrm{NW}$ Amealco; 4 km SW Amealco; 1 km W desviación, San Pedro Tenango: N. leucodon (recorded as N. albigula), N. goldmani, P. levipes. Maguey Verde: N. leucodon (recorded as N. albigula leucodon), N. goldmani, P. gratus (recorded as P. truei gratus), P. difficilis, P. pectoralis (Acosta 2003; Acosta et al. 2008). Specimens in collections: MZFC. TLAXCALA: Calpulalpan: Peromyscus difficilis (Barrera 1953). $10 \mathrm{~km}$ E Calpulalpan: $P$. difficilis (Ayala-Barajas et al. 1988). Tlaxco: Peromyscus sp. La Malinche: Neotomodon alstoni, P. difficilis, P. gratus, P. leucopus, P. levipes, P. maniculatus, P. melanotis, Reithrodontomys fulvescens, Heteromys irroratus (Ayala-Barajas et al. 1988; Aguilar-Montiel et al. 2018). Sanctorum de Lázaro Cárdenas, Camino Rural Benito Juárez, La Joya: P. maniculatus (Acosta et al. 2008). Specimens in collections: MZFC. Note: Several additional records from Traub (1950) with unclear localites and host associations. Note: $P$. furvus is not distributed in Tlaxcala according to Ceballos (2014). VERACRUZ: $3 \mathrm{~km} \mathrm{~S} \mathrm{El}$ Frijol Colorado, Mpio. de Perote: Peromyscus difficilis (Falcón- 
Ordaz et al. 2012). Specimens in collections: MZFC. ZACATECAS: Cerro el Panal: Peromycus sp. (Ayala-Barajas et al. 1988). Specimens in collections: MZFC. ORIENTAL BASIN: Multiple localities in Puebla, Tlaxcala, and Veracruz: Peromyscus difficilis, P. furvus, P. maniculatus, Peromyscus sp. (Acosta and Fernández 2015). Specimens in collections: MZFC.

\section{Pleochaetis paramundus Traub, 1950}

CIUDAD DE MÉXICO: El Zarco: Peromyscus melanotis (Barrera 1953; Ayala-Barajas et al. 1988). El Guadra: P. hylocetes (Barrera 1953). La Cima: Peromyscus sp. Parres: Neotomodon alstoni, Neotomodon sp. 2 km S Parres: Neotomodon sp. (Ayala-Barajas et al. 1988). Specimens in collections: MZFC. Note: Neotomodon sp. likely refers to Neotomodon alstoni, as this is the only species in the genus ( $N$. orizabae and $N$. perotensis were synonymized with $N$. alstoni). DURANGO: Hidalgo, 4 km S-SE of la Zarca: Onychomys torridus, Peromyscus maniculatus (Acosta et al. 2006; 2008). Specimens in collections: MZFC. Note: O. torridus is not distributed in Durango according to Ceballos (2014). ESTADO DE MÉXICO: Slopes of Volcán Popocatépetl: Peromyscus melanotis (Barrera 1953). Popocatépetl, P. hylocetes, P. melanotis. Popocatépetl, Mirador del Poeta, Neotomodon alstoni. Popocatépetl, Diego de Ordaz, N. alstoni (Ayala-Barajas et al. 1988). Popocatépetl, Microtus mexicanus, N. alstoni, P. maniculatus, P. melanotis, Reithrodontomys chrysopsis, R. megalotis (Barrera 1968). Cerro Tlamacas: M. mexicanus, N. alstoni, $P$. melanotis. Monte Río Frío: N. alstoni, Neotoma mexicana (recorded as N. torquata mexicana), Peromyscus sp. $5 \mathrm{~km}$ SO Parres; Popocatépetl, Mirador del Poeta; Popocatépetl, Diego de Ordaz: N. alstoni (Ayala-Barajas et al. 1988). Specimens in collections: MZFC. GUERRERO: Chilpancingo de los Bravo, Omiltemi, Cañada de Agua Fría: Megadontomys thomasi (Acosta et al. 2008). Specimens in collections: MZFC. MICHOACÁN: Tancítaro: Neotomodon alstoni (Traub 1950). Specimens in collections: FMNH. MORELOS: $5.5 \mathrm{~km}$ $\mathrm{N}$ of Tres Cumbres: Neotomodon alstoni (Barrera 1953). Km 11 Tres Cumbres-Zempoala Highway: Peromyscus hylocetes (Barrera 1954a). $3 \mathrm{~km} \mathrm{~S}$ of Zempoala: P. hylocetes. $9 \mathrm{~km} \mathrm{~N}$ of Tres Marias: N. alstoni (Ayala-Barajas et al. 1988). Specimens in collections: MZFC. OAXACA: Ixtlán de Juárez, 8.75 km SE of Santa María Yavesía: Peromyscus difficilis (Acosta et al. 2008). Specimens in collections: MZFC. PUEBLA: La Esperanza: Peromyscus sp. (Acosta et al. 2008). Specimens in collections: MZFC. QUERÉTARO: Peñamiller, Maguey Verde: Peromyscus difficilis (Acosta et al. 2008). Specimens in collections: MZFC. TLAXCALA: $10 \mathrm{~km}$ NE of Calpulalpan: Neotomodon sp. La Malinche: Neotomodon alstoni, Peromyscus difficilis, P. maniculatus, P. melanotis, Reithrodontomys chrysopsis, R. fulvescens (Ayala-Barajas et al. 1988; Acosta and Fernández 2006; Aguilar-Montiel et al. 2018). Huamantla, La Malinche (Caseta \#4): N. alstoni, R. chrysopsis. Tlaxco: N. alstoni (Acosta et al. 2008). Specimens in collections: MZFC. Note: Neotomodon sp. likely refers to Neotomodon alstoni, as this is the only species in the genus ( $N$. orizabae and $N$. perotensis were synonymized with $N$. alstoni).
Pleochaetis sp.

GUERRERO: Puerto Chico, 38 km W of Xochipala: Megadontomys thomasi. $35 \mathrm{~km}$ SW of Xochipala: Peromyscus sp. (Ayala-Barajas et al. 1988). Specimens in collections: MZFC. QUERÉTARO: 3.7 km SW of Ahuacatlán de Guadalupe; 13.76 $\mathrm{km} \mathrm{W}$ of Amealco; $17 \mathrm{~km} \mathrm{~N}$ of Amealco: Peromyscus levipes. $6.24 \mathrm{~km}$ W of Amealco: Reithrodonomys fulvescens. Maguey Verde: P. difficilis. $1 \mathrm{~km}$ S of Pinal de Amoles: Neotoma mexicana, $P$. difficilis, $P$. levipes, Peromyscus sp., $R$. fulvescens, $R$. sumichrasti. Pinal de Amoles: P. difficilis, P. levipes. Camargo: P. pectoralis, P. difficilis. $1 \mathrm{~km}$ S of Ahuacatlán de Guadalupe: P. levipes (Acosta 2003). Tequisquiapan, $5 \mathrm{~km}$ SW of Tequisquiapan: P. gratus (Acosta et al. 2008). Specimens in collections: MZFC. SIERRA MADRE ORIENTAL: Multiple localities: Peromyscus gratus (Gutiérrez-Velázquez and Acosta 2004). Specimens in collections: MZFC.

Plusaetis apollinaris (Jordan and Rothschild, 1921)

CIUDAD DE MÉXICO: Cuajimalpa de Morelos, Cabeza del Toro, Parque Nacional Desierto de los Leones: Peromyscus maniculatus (Acosta et al. 2008). Specimens in collections: MZFC. GUERRERO: Atoyac de Álvarez, El Molote: Megadontomys sp. (Acosta et al. 2008). Specimens in collections: MZFC. HIDALGO: Cuatepec de Hinojosa, 4 km W of San Lorenzo Sayula: Peromyscus sp. (Acosta et al. 2008). Specimens in collections: MZFC. OAXACA: Ixtlán de Juárez, 2.5 km SE of Santa María Yavesía: Peromyscus gratus (recorded as P. truei). Ixtlán de Juárez, $6.5 \mathrm{~km} \mathrm{E-SE} \mathrm{of}$ Santa María Yavesía: P. aztecus, P. difficilis, P. melanocarpus. Ixtlán de Juárez, 8.75 km SE of Santa María Yavesía: Microtus mexicanus, P. difficilis (Acosta et al. 2008). Specimens in collections: MZFC. PUEBLA: Atzitzintla, Santa Cruz Cuyachapa, Ejido Maguey Cenizo: Peromyscus sp. (Acosta et al. 2008). Specimens in collections: MZFC. QUERÉTARO: $4 \mathrm{~km}$ NE of Ahuacatlán de Guadalupe: Peromyscus pectoralis. 11 km Galindo-Amealco Highway; 1 km NW of Santa Inés: $P$. levipes. Peña Bernal: P. difficilis. 9 km SE of Tequisquiapan: Baiomys taylori (Acosta 2003). Tequisquiapan, Tequisquiapan: Heteromys irroratus (Acosta et al. 2008). Specimens in collections: MZFC. TLAXCALA: Huamantla, La Malinche (Caseta \#4): Microtus mexicanus, Neotomodon alstoni, Peromyscus gratus, P. melanotis, Peromyscus sp., Reithrodontomys chrysopsis, R. megalotis. Ixtenco La Malinche (Caseta \#5): N. alstoni, R. chrysopsis, R. megalotis, Peromyscus sp. Tlaxco: Neotomodon alstoni (Acosta and Fernández 2006; Acosta et al. 2008). Specimens in collections: MZFC. ORIENTAL BASIN: Multiple localities in Puebla and Tlaxcala: Peromyscus furvus, P. maniculatus (Acosta and Fernández 2015). Specimens in collections: MZFC. Note: P. furvus is not distributed in Tlaxcala according to Ceballos (2014).

Plusaetis asetus (Traub, 1950)

ESTADO DE MÉXICO: Popocatépetl: Microtus mexicanus, Peromyscus maniculatus, P. melanotis (Ayala-Barajas et al. 1988). Slopes of Popocatépetl: M. mexicanus, P. manicu- 
latus. Popocatépetl, Mirado del Poeta; Iztaccíhuatl, vert. Oriental: Microtus mexicanus. Popocatépetl, Paraje Providencial: Peromyscus sp. Popocatépetl, Mirador de Nexpayatla: Microtus sp. (Ayala-Barajas et al. 1988). Popocatépetl: Microtus mexicanus, P. maniculatus, P. melanotis (Barrera. 1968). Specimens in collections: MZFC. NUEVO LEÓN: Cerro Potosí: Microtus mexicanus, P. difficilis, P. melanotis (Tipton and Mendez 1968). Unknown if specimens are in collections. El Potosí: Microtus sp. (Ayala-Barajas et al. 1988). Sierra Madre Oriental: Microtus sp. (Gutiérrez-Velázquez and Acosta 2004). Specimens in collections: MZFC. PUEBLA: San Juan Tetla, Mpio. de Chiautzingo: Microtus mexicanus (Ramírez 1982). Unknown if specimens are in collections.

\section{Plusaetis aztecus (Barrera, 1954)}

CIUDAD DE MÉXICO: El Guarda: Neotomodon alstoni. La Venta: $P$. gratus (recorded as $P$. truei gratus), Peromyscus maniculatus. El Zarco: P. gratus (recorded as P. truei gratus; Barrera 1953b; Machado-A. 1960). La Cima: Peromyscus sp. El Zarco: P. maniculatus. Parres: N. alstoni, Peromyscus sp. $2 \mathrm{~km} \mathrm{SW}$ of Parres; $2 \mathrm{~km}$ S of Parres: Neotomodon sp., Reithrodontomys sp. $5 \mathrm{~km}$ SW of Parres: N. alstoni. San NW Cayetano: Reithrodontomys sp. (Ayala-Barajas et al. 1988). Specimens in collections: MZFC or unknown. Note: Neotomodon sp. likely refers to Neotomodon alstoni, as this is the only species in the genus ( $N$. orizabae and $N$. perotensis were synonymized with $N$. alstoni). Parque Nacional Insurgente Miguel Hidalgo y Costilla: Microtus mexicanus, P. maniculatus, Reithrodontomys megalotis (Méndez-L. 1974). Unknown if specimens are in collections. ESTADO DE MÉXICO: Slopes of Volcán Popocatépetl and La Venta: Peromyscus maniculatus (Barrera 1954b). Popocatépetl: P. maniculatus, Peromyscus sp., Reithrodontomys chrysopsis. Popocatépetl, 3.5 km E of San Pedro Nexapa: Peromyscus sp. Popocatépetl, Mirador de Nexpayantla: P. melanotis. Popocatépetl, Mirado del Poeta: P. melanotis, Peromyscus sp. Popocatépetl, Paso de Cortes; Popocatépetl, Paraje Diego de Ordaz: N. alstoni. Popocatépetl, Tlamacas: P. melanotis, R. chrysopsis. Popocatépetl, Paraje Providencial: P. maniculatus. $5 \mathrm{mi} \mathrm{W}$ of Río Frío: N. alstoni. $4 \mathrm{~km} \mathrm{~W}$ of Río Frío: Reithrodontomys sp. Zumpango: Reithrodontomys sp. (Ayala-Barajas et al. 1988). Popocatépetl: Microtus mexicanus, Neotomodon alstoni, $P$. difficilis, P. maniculatus, P. melanotis, R. chrysopsis (Barrera 1968). Specimens in collections: MZFC. San Cayetano: $M$. mexicanus, Peromyscus sp. (Machado-A. 1960). Unknown if specimens are in collections. JALISCO: Nevado de Colima: Microtus mexicanus, Peromyscus melanotis (Ayala-Barajas et al. 1988). Specimens in collections: MZFC. MORELOS: Tres Cumbres: Neotomodon alstoni (Barrera 1953). Specimens in collections: MZFC. NUEVO LEÓN: Cerro Potosí: Microtus mexicanus, Neotoma leucodon (recorded as N. albigula), Peromyscus difficilis, P. melanotis, Peromyscus sp. (Tipton and Mendez 1968). Unknown if specimens are in collections. PUEBLA: San Juan Tetla, Mpio. de Chiautzingo: Reithrodontomys megalotis (Ramírez 1982). Unknown if specimens are in collections. TLAXCALA: 10 km NE of Calpulalpan: Reithro- dontomys sp. La Malinche: Microtus mexicanus, Neotoma mexicana, Neotomodon alstoni, Peromyscus difficilis, P. gratus, P. levipes, P. maniculatus, P. melanotis, Reithrodontomys chrysopsis, R. fulvescens, R. megalotis, R. sumichrasti (AyalaBarajas et al. 1988; Acosta and Fernández 2006; AguilarMontiel et al. 2018). Specimens in collections: MZFC.

Plusaetis dolens dolens (Jordan and Rothschild, 1914)

CIUDAD DE MÉXICO: Pedregal de San Ángel: Peromyscus gratus (recorded as $P$. truei gratus). La Venta: $P$. gratus (recorded as P. truei gratus), P. maniculatus. Zacatepec: $P$. gratus (recorded at $P$. truei gratus; Barrera 1953). Specimens in collections: MZFC. Parque Nacional Insurgente Miguel Hidalgo y Costilla: P. maniculatus (Méndez-L. 1974). Unknown if specimens are in collections. ESTADO DE MÉXICO: Popocatépetl: Microtus mexicanus, Peromyscus difficilis, P. maniculatus, Reithrodonomys chrysopsis, R. megalotis (Barrera 1968). $4.5 \mathrm{~km}$ E of Chiconautla: Peromyscus sp. (Ayala-Barajas et al. 1988). Specimens in collections: MZFC. GUERRERO: Atoyac de Álavarez, El Molote: Megadontomys sp. Chilpancingo de los Bravo, Omiltemi: Megadontomys thomasi. Omiltemi, Cueva de Borrega: Peromyscus boylii. San Miguel Totolapan, Estación Toro Muerto: Peromyscus sp., Reithrodontomys sp. (Acosta et al. 2008). Specimens in collections: MZFC. Note: P. boylii is not distributed in Guerrero according to Ceballos (2014). HIDALGO: Arroyo Piedras Negras: Peromyscus difficilis, Reithrodontomys megalotis (Barrera 1953). Specimens in collections: MZFC. MICHOACÁN: Monte San Miguel Tancítaro: Peromyscus hylocetes (Traub 1950). Unknown if specimens are in collections. Coalcoman de Vázquez Pallares, Pallares, 11.84 km SW of Dos Aguas: P. winkelmanni (Acosta et al. 2008). Specimens in collections: MZFC. MORELOS: Derrame del Chichinautzin: Neotoma mexicana, Peromyscus difficilis (Pérez-Ortiz 1976; Ayala-Barajas et al. 1988). Specimens in collections: MZFC. OAXACA: Ixtlán de Juárez, 8.75 km SE of Santa María Yavesía: Peromyscus difficilis (Acosta et al. 2008). Specimens in collections: MFZC. PUEBLA: La Esperanza: Peromyscus melanophrys, Peromyscus sp., Reithrodontomys sp. (Acosta et al. 2008). Specimens in collections: MZFC. QUERÉTARO: Amealco de Bonfil, $17 \mathrm{~km}$ N of Amealco: Peromyscus levipes (recorded as P. boylii levipes). $9 \mathrm{~km} \mathrm{~N}$ of Amealco Highway: Baiomys taylori. Cadereyta de Montes, 1 km SE of Chavarría: P. difficilis. El Pemoche: Handleyomys chapmani (recorded as Oryzomys chapmani), Reithrodonomys mexicanus. $1 \mathrm{~km}$ $S$ of Pinal de Amoles: $R$. sumichrasti (Acosta 2003; Acosta et al. 2008). Specimens in collections: MZFC. SAN LUIS POTOSÍ: 11 km SE of Santa Maria del Río: Peromyscus sp. (Ayala-Barajas et al. 1988). Specimens in collections: MZFC. TLAXCALA: Calpulalpan: Peromyscus difficilis (Barrera 1953). Specimens in collections: MZFC. La Malinche: Neotoma mexicana, Neotomodon alstoni, P. difficilis, P. gratus, P. levipes, P. melanotis (Aquilar-Montiel et al. 2018). Tlaxco, Predio Hermanos Cabrera; Hueyotlipan, 2 km E of San Andres Cuajimalpa: Peromycus sp. El Carmen Tequexquitla, El Piñonal; El Carmen Tequexquitla, El Piñonal: $P$. difficilis. Ixtenco, La 
Malinche (Caseta \#5): N. alstoni. Huamantla, La Malinche (Caseta \#4): N. alstoni (recorded as Peromyscus alstoni), P. gratus, Reithrodontomys chrysopsis, R. megalotis. Españita, 3 km NW of Vicente Guerrero: R. megalotis, Reithrodontomys sp. (Acosta et al. 2008). Specimens in collections: MZFC. VERACRUZ: Xico, Texolo: Peromyscus mexicanus (Acosta et al. 2008). Specimens in collections: MZFC.

\section{Plusaetis equatoris (Jordan, 1933)}

CIUDAD DE MÉXICO: El Guarda: Neotomodon alstoni (Barrera 1953). Specimens in collections: IBUNAM. La Venta: Peromyscus maniculatus, $P$. truei (recorded as $P$. truei gratus). El Zarco: P. maniculatus (Barrera 1953). Specimens in collections: MZFC. ESTADO DE MÉXICO: Slopes of Volcán Popocatépetl: Peromyscus maniculatus (Barrera 1953). Specimens in collections: MZFC.

\section{Plusaetis mathesoni (Traub, 1950)}

CHIAPAS: Puebla Nuevo: Neotoma mexicana (Hubbard 1958). Specimens in collections: Unknown, possibly BMNH. CIUDAD DE MÉXICO: Km 42 highway to Cuernavaca: Peromyscus hylocetes. La Venta: P. gratus (recorded as $P$. truei gratus), $P$. hylocetes, $P$. maniculatus. $5 \mathrm{~km} \mathrm{SW}$ of Parres: Neotomodon alstoni (Ayala-Barajas et al. 1988). Cuajimalpa de Morelos, El Pantano, Parque Nacional Desierto de los Leones: P. maniculatus. Parte del Sendero Turístico, Parque Nacional Desierto de los Leones: $P$. difficilis. $1 \mathrm{~km}$ del Potrillo, Parque Nacional Desierto de los Leones: $N$. alstoni (recorded as Peromyscus alstoni), P. difficilis, Peromyscus sp. Sabandijas, Parque Nacional Desierto de los Leones: R. chrysopsis (Acosta et al. 2008). Specimens in collections: MZFC. El Zarco: Microtus mexicanus, Peromyscus hylocetes, P. maniculatus, Peromyscus sp., Reithrodontomys sp. (Machado-A. 1960; Ayala-Barajas et al. 1988). Parque Nacional Insurgente Miguel Hidalgo y Costilla: M. mexicanus, P. maniculatus, R. megalotis (Méndez-L. 1974). Unknown if specimens are in collections. ESTADO DE MÉXICO: Popocatépetl: Microtus mexicanus, Neotomodon alstoni, Peromyscus difficilis, P. maniculatus, P. melanotis, Peromyscus sp., Reithrodontomys chrysopsis, R. megalotis (Barrera 1968; Ayala-Barajas et al. 1988). Lagunas de Zempoala, Ojotongo; Nevado de Toluca, 4 mi S of Raíces; San Cayetano; 4 km W of Río Frío: Reithrodontomys sp. Popocatépetl, Paraje Diego de Ordaz: N. alstoni, P. maniculatus, Reithrodontomys sp. Popocatépetl, Paraje Providencial: P. maniculatus, R. chrysopsis. Popocatépetl, San Pedro Nexapa: P. difficilis, Reithrodontomys sp. Slopes of Popocatépetl: P. hylocetes. Monte Río Frío; 5 mi W of Río Frío: N. alstoni (Ayala-Barajas et al. 1988). Zacualpan, Zacualpan-Mamatla Highway, km 7: P. difficilis (Acosta et al. 2008). Specimens in collections: MZFC. GUERRERO: Omiltemi: Megadontomys thomasi (Barrera 1958). Chilpancingo de los Bravo, 3.5 km SW of Omiltemi; Chilpancingo de los Bravo, Omiltemi: Peromyscus megalops. Chilpancingo de los Bravo, $1 \mathrm{~km}$ W of Omiltemi: Handleyomys chapmani (recorded as Oryzomys chapmani), M. thomasi. Atoyac de
Álvarez, El Molote: Peromyscus sp. (Acosta et al. 2008). Specimens in collections: MZFC. HIDALGO: El Chico: Peromyscus maniculatus (Barrera 1953; Ayala-Barajas et al. 1988). Sierra Madre Oriental: P. maniculatus (Gutiérrez-Velázquez and Acosta 2004). Specimens in collections: MZFC. JALISCO: Nevado de Colima: Peromyscus melanotis (Ayala-Barajas et al. 1988). Specimens in collections: MZFC. MICHOACÁN: Tancítaro: Reithrodontomys chrysopsis, Peromyscus hylocetes (Traub 1950). Specimens in collections: FMNH. MORELOS: Lagunas de Zempoala; Lagunas de Zempoala, $1 \mathrm{~km}$ NE of la Laguna; Km 11 of the Tres Cumbres-Zempoala Highway; Km 14 Tres Cumbres-Zempoala Highway: Peromyscus hylocetes. Ojo de Agua de Aclasingo: Microtus mexicanus (Barrera 1954a). Derrame del Chichinautzin: P. hylocetes, Reithrodontomys chrysopsis (Pérez-Ortiz 1976). Cuenca de "México" (sic), multiple localities above $2600 \mathrm{~m}$ in altitude: $R$. megalotis, P. hylocetes, P. maniculatus (Barrera 1954b). Atzompa; Zempoala: P. hylocetes. Derrame Chichinautzin: P. difficilis. $9 \mathrm{~km} N$ of Tres Marias: Neotomodon alstoni (Ayala-Barajas et al. 1988). Specimens in collections: MZFC. OAXACA: Ixtlán de Juárez, $1.5 \mathrm{~km}$ SE of Santa María Yavesía: Peromyscus aztecus. Ixtlán de Juárez, 2.5 km SE of Santa María Yavesía: P. aztecus, P. gratus (recorded as P. truei), P. mexicanus. Ixtlán de Juárez, 4 km SE of Santa María Yavesía: P. aztecus, P. mexicanus. Ixtlán de Juárez, $4.5 \mathrm{~km}$ SE of Santa María Yavesía: P. mexicanus, Reithrodontomys mexicanus. Ixtlán de Juárez, 6.5 km E-SE of Santa María Yavesía: P. difficilis, P. gratus (recorded as P. truei). Ixtlán de Juárez, 8.75 km SE of Santa María Yavesía: P. difficilis (Acosta et al. 2008). Specimens in collections: MZFC. PUEBLA: La Esperanza: Peromyscus sp. (Acosta et al. 2008). 1 km S Santa Cruz Coyotepec, Mpio. de San Salvador El Seco: Peromyscus difficilis (Falcón-Ordaz et al. 2012). Specimens in collections: MZFC. QUERÉTARO: $6.24 \mathrm{~km} \mathrm{~W}$ of Amealco: Peromyscus levipes. $9 \mathrm{~km} \mathrm{~N}$ of Amealco Highway; Peñamiller; Amealco de Bonfil, Amealco-La Estancia Highway, km 9: P. difficilis, Peromyscus sp. Peñamiller: Sigmodon sp. $1 \mathrm{~km} \mathrm{~S}$ of Pinal de Amoles: P. difficilis, P. levipes (recorded as P. levipes and P. boylii levipes). $1 \mathrm{~km} \mathrm{SW}$ of Pinal de Amoles: P. levipes, Reithrodontomys megalotis. Pinal de Amoles, $1.2 \mathrm{~km}$ S of Pinal de Amoles: Neotoma mexicana, P. boylii. Pinal de Amoles, $1 \mathrm{~km}$ SW of Ahuacatlán de Guadalupe: P. levipes (recorded as P. boylii levipes; Acosta 2003; Acosta et al. 2008). Specimens in collections: MZFC. TLAXCALA: 10 km NE of Calpulalpan: Neotomodon sp., Reithrodontomys sp. La Malinche: Neotomodon alstoni, Peromyscus difficilis, P. gratus, P. leucopus, P. maniculatus, P. melanotis, Reithrodontomys fulvescens (Ayala-Barajas et al. 1988; Acosta and Fernández 2006; Aguilar-Montiel et al. 2018). Huamantla, La Maliche (Caseta \#4): P. gratus, Peromyscus sp. Ixtenco, La Malinche (Caseta \#5); Hueyotlipan, 2 km E of San Andrés Cuajimalpa: Peromyscus sp. Calpulalpan, San Felipe Hidalgo, Piedra Canteada: Neotoma mexicana. El Carmen Tequexquitla, El Piñonal: P. difficilis. Sanctorum de Lázaro Cárdenas, Camino Rural Benito Juárez, La Joya: Reithrodontomys sp. Panotla, San Ambrosio Texantla, Barranca Huehuetitla: Heteromys irroratus (Acosta et al. 2008). Speci- 
mens in collections: MZFC. Note: Neotomodon sp. likely refers to Neotomodon alstoni, as this is the only species in the genus ( $N$. orizabae and $N$. perotensis were synonymized with N. alstoni). VERACRUZ: Ixhuatlancillo, Rancho La Pala: Peromyscus sp. (Acosta et al. 2008). Specimens in collections: MZFC. ORIENTAL BASIN: Multiple localities in Puebla, Tlaxcala, and Veracruz: Peromyscus difficilis, P. maniculatus, Reithrodontomys megalotis, Heteromys irroratus (Acosta and Fernández 2015). Specimens in collections: MZFC.

\section{Plusaetis parus (Traub, 1950)}

CIUDAD DE MÉXICO: Ciudad Universitaria; Cerro Zacatepec; $1.5 \mathrm{~km} \mathrm{E,} 300 \mathrm{~m}$ S of Cerro Zacatepec; $400 \mathrm{~m}$ N of Cerro Zacatepec; Pedregal Zacatepec; Pedregal de San Ángel; Pedregal de San Ángel, Cd. Universitaria: Peromyscus gratus (recorded as P. truei gratus); La Venta: P. gratus (recorded as $P$. truei gratus), P. maniculatus (Ayala-Barajas et al. 1988). Specimens in collections: MZFC. ESTADO DE MÉXICO: Chilpa: Peromyscus sp., Reithrodontomys sp. $4.5 \mathrm{~km}$ E of Chiconautla; Popopark: Peromyscus sp. Tlalnepantla: Reithrodontomys sp., Sigmodon sp. $2 \mathrm{~km} N$ of Tlalnepantla: Baiomys sp., Peromyscus gratus (recorded as P. truei), Heteromys sp. (Ayala-Barajas et al. 1988). Specimens in collections: MZFC. GUERRERO: Camotla, Leonardo Bravo: Peromyscus gratus (recorded as $P$. truei gratus). Omiltemi: Oryzomys sp., Peromyscus sp., Reithrodontomys sp. $35 \mathrm{~km} \mathrm{SW}$ of Xochipala: P. boylii. $22 \mathrm{~km}$ SW of Yextla: P. megalops (Ayala-Barajas et al. 1988). Specimens in collections: MZFC. Note: $P$. boylii is not distributed in Guerrero according to Ceballos (2014). Note: Oryzomys sp. was recorded in the original literature but may represent Handleyomys sp. HIDALGO: Arroyo Piedras Negras: Peromyscus difficilis, Reithrodontomys sp. Road between Sn. Juan Huayapam and Presa San Carlos Huasca; 10 km S of "El Blanco", Zacualtipan: Peromyscus sp. (Ayala-Barajas et al. 1988). Specimens in collections: MZFC. MICHOACÁN: Tlalpujahua: Peromyscus maniculatus, Reithrodontomys sp. $3 \mathrm{~km}$ SW of San Francisco Tlalpujahua: P. maniculatus (Ayala-Barajas et al. 1988). Specimens in collections: MZFC. PUEBLA: $1 \mathrm{~km}$ SW of Sn. Pedro Atlixco: Peromyscus difficilis. $1 \mathrm{mi}$ NE of Alchichica: Reithrodontomys sp. $12 \mathrm{~km} \mathrm{~W}$ of Ateuco de Aljojuca, San Salvador El Seco: Peromyscus sp. (Ayala-Barajas et al. 1988). $1.5 \mathrm{~km} \mathrm{~S}$ Oriental, Mpio. de Oriental; 2 km W Guadalupe Victoria, Mpio. de Guadalupe Victoria: P. difficilis (Falcón-Ordaz et al. 2012). Specimens in collections: MZFC. TLAXCALA: $10 \mathrm{~km}$ E of Calpulalpan: Peromyscus difficilis. La Malinche: Neotomodon alstoni, P. difficilis, P. leucopus, P. levipes, P. maniculatus, P. melanotis, Reithrodontomys fulvescens (Ayala-Barajas et al. 1988; Acosta and Fernández 2006; Aguilar-Montiel et al. 2018). 2.5 km NW El Carmen Tequexquitla, Mpio. de El Carmen Tequexquitla: P. difficilis (Falcón-Ordaz et al. 2012). Specimens in collections: MZFC. SIERRA MADRE ORIENTAL: Multiple localities in Coahuila, Guanajuato, Hidalgo, Nuevo León, Puebla, Querétaro, Tamaulipas, and Veracruz: Peromyscus maniculatus, P. difficilis, Reithrodontomys sp., Reithrodontomys megalotis (Gutiérrez-Velázquez and Acosta 2004).
Specimens in collections: MZFC. ORIENTAL BASIN: Multiple localities in Puebla, Tlaxcala, and Veracruz: $P$. difficilis, P. levipes, P. maniculatus, Peromyscus sp., Reithrodontomys fulvescens, R. megalotis, Dipodomys phillipsii, Heteromys irroratus (Acosta and Fernández 2015). Specimens in collections: MZFC. VERACRUZ: 3 km S El Frijol Colorado, Mpio. de Perote: Peromyscus difficilis, Reithrodontomys megalotis (Falcón-Ordaz et al. 2012). Specimens in collections: MZFC.

\section{Plusaetis ponsi (Barrera, 1955)}

CIUDAD DE MÉXICO: Cuajimalpa de Morelos, Cabeza del Toro, Parque Nacional Desierto de los Leones: Peromyscus maniculatus (Acosta et al. 2008). Specimens in collections: MZFC. GUERRERO: Omiltemi: Megadontomys thomasi (Barrera 1955b, 1958). Specimens in collections: CAIM, InDRE, MZFC, USNM. Camotla, Chihihualco: Osgoodomys banderanus (recorded as Peromyscus banderanus vicinior). $1 \mathrm{mi} \mathrm{NW}$ of Omiltemi: Peromyscus sp. Puerto Chico, $38 \mathrm{~km} \mathrm{SW}$ of Xochipala: M. thomasi, P. boylii evidens. Agua Fría, 22 km SW of Yextla: P. megalops (Ayala-Barajas et al. 1988). Atoyac de Álvarez, Puerto del Gallo-Paraíso Highway, km 14: M. thomasi, Peromyscus sp. La Golondrina; $3.5 \mathrm{~km}$ E of Omiltemi: $P$. megalops. Chilpancingo de los Bravo, Omiltemi: M. thomasi, P. levipes, P. megalops. Omiltemi, Cañada de Agua Fría: Handleyomys guerrerensis (recorded as Orzyomys chapmani guerrerensis), $M$. thomasi, P. levipes. $2.5 \mathrm{~km}$ E of Omiltemi: $M$. thomasi. San Miguel Totolapan, Estación Toro Muerto: Peromyscus sp., Reithrodontomys sp. Puerto del Gallo: M. thomasi, P. megalops. Tlacotepec, Cerro de Teotepec: P. boylii. Atoyac de Álvarez, El Molote; Leonardo Bravo, Carrizal del Bravo: Peromyscus sp. (Acosta et al. 2008). Specimens in collections: MZFC. Note: P. boylii and H. guerrerensis are not distributed in Guerrero according to Ceballos (2014).

\section{Plusaetis sibynus jordani (Barrera, 1955)}

CIUDAD DE MÉXICO: El Guarda: Peromyscus hylocetes (Barrera 1953). La Venta: P. gratus (recorded as P. truei gratus), P. hylocetes, P. maniculatus (Barrera 1953). Km 42 Free México-Cuernavaca Highway: Peromyscus hylocetes. El Zarco, Cerro de los Tepalcates, El Zarco: P. maniculatus. 1 km SE El Zarco: Peromyscus maniculatus (Barrera 1955a). La Cima: Peromyscus sp. El Zarco: P. maniculatus, Peromyscus sp. La Venta: P. gratus (recorded as $P$. truei gratus), $P$. hylocetes, P. maniculatus. Parres: Neotomodon alstoni, Peromyscus sp. $2 \mathrm{~km} \mathrm{~S}$ of Parres: Neotomodon sp. (Ayala-Barajas et al. 1988). Specimens in collections: MZFC. Note: Neotomodon sp. likely refers to Neotomodon alstoni, as this is the only species in the genus ( $N$. orizabae and $N$. perotensis were synonymized with $N$. alstoni). Parque Nacional Insurgente Miguel Hidalgo y Costilla: Microtus mexicanus, P. maniculatus (Méndez-L. 1974). Unknown if specimens are in collections. ESTADO DE MÉXICO: Slopes of Volcán Popocatépetl: Peromyscus hylocetes, P. maniculatus, P. melanotis (Barrera 1953; 1955a). Slopes of Volcán Popocatépetl: Microtus mexicanus, Neotomodon alstoni, P. difficilis, Peromyscus sp., 
Reithrodontomys chrysopsis (Barrera 1955a; Barrera 1968; Ayala-Barajas et al. 1988). Specimens in collections: MZFC. Mt. Popocatépetl; Slopes of Volcán Popocatépetl: P. maniculatus. Volcán Popocatépetl; Popocatépetl, Otlaltepec; Popocatépetl, Paso de Cortes; Monte Río Frío; Río Frío: Peromyscus sp. Popocatépetl, cerca Tlamacas: N. alstoni, Neotomodon sp., P. melanotis. Popocatépetl, $300 \mathrm{~m}$ SW of Tlamacas; Popocatépetl, Mirador del Poeta: P. melanotis. Popocatépetl, Mirador de Nexpayantla: P. melanotis, Peromyscus sp. Popocatépetl, Paraje Diego de Ordaz: M. mexicanus, P. maniculatus, Peromyscus sp. Popocatépetl, San Pedro Nexapa: P. difficilis. Popocatépetl, Paraje Providencial; Popocatépetl, $9 \mathrm{~km} \mathrm{~W}$ and $1.5 \mathrm{~km} \mathrm{~N}$ of Xalizintla: P. maniculatus, Peromyscus sp. (Ayala-Barajas et al. 1988). Specimens in collections: MZFC. Note: Neotomodon sp. likely refers to Neotomodon alstoni, as this is the only species in the genus ( $N$. orizabae and $N$. perotensis were synonymized with N. alstoni). HIDALGO: Arroyo Piedras Negras: Peormyscus difficilis (Barrera 1953). Specimens in collections: MZFC. MICHOACÁN: Monte Tancítaro: Microtus mexicanus, Peromyscus melanotis (Traub 1950). Specimens in collections: FMNH. MORELOS: Km 42 highway to Cuernavaca: Peromyscus hylocetes (AyalaBarajas et al. 1988). Specimens in collections: MZFC. VERACRUZ: Cofe de Perote: Reithrodontomys sp. (Ayala-Barajas et al. 1988). Sierra Madre Oriental: Reithrodontomys sp. (Gutiérrez-Velázquez and Acosta 2004). Specimens in collections: MZFC.

Plusaetis sibynus (Jordan, 1925)

CHIHUAHUA: Rancho La Cruz Guachochic-Batopilas: Peromyscus maniculatus (Barrera 1955a). Rancho La Cruz, $30 \mathrm{~km}$ SW of Guachochic: Peromyscus maniculatus (AyalaBarajas et al. 1988). Specimens in collections: MZFC. CIUDAD DE MÉXICO: La Cima: Peromyscus sp. La Venta: P. gratus (recorded as P. truei gratus), P. hylocetes, P. maniculatus. Parres: Peromyscus sp., Neotomodon alstoni. $2 \mathrm{~km} \mathrm{~S}$ of Parres: Neotomodon sp. (Ayala-Barajas et al. 1988). Specimens in collections: MZFC. Note: Neotomodon sp. likely refers to Neotomodon alstoni, as this is the only species in the genus ( $N$. orizabae and $N$. perotensis were synonymized with N. alstoni). DURANGO: $8 \mathrm{~km}$ W of El Salto: Peromyscus sp. (Ayala-Barajas et al. 1988). Specimens in collections: MZFC. GUERRERO: General Heliodoro Castillo, El Iris: Megadontomys thomasi. San Miguel Totolapan, Puerto del Gallo: Peromyscus boylii (Acosta et al. 2008). Specimens in collections: MZFC. Note: P. boylii is not distributed in Guerrero according to Ceballos (2014). JALISCO: Nevado de Colima: Peromyscus melanotis (Ayala-Barajas et al. 1988). Specimens in collections: MZFC. MICHOACÁN: Monte Tancítaro: Peromyscus melanotis (Jordan 1925). Unknown if specimens are in collections. MORELOS: $\mathrm{km} 42$ highway to Cuernavaca: Peromyscus hylocetes (Ayala-Barajas et al. 1988). Specimens in collections: MZFC. NUEVO LEÓN: Ojo de Agua, Galena, and Cerro Potosí: Microtus sp., Peromyscus sp. (Fox 1939; Traub 1950). Cerro Potosí: Microtus mexicanus, Microtus sp., Neotoma leucodon (recorded as N. albigula), Peromyscus difficilis, P. melanotis, Peromyscus sp., Reithrodontomys fulvescens (Traub 1950; Tipton and Mendez 1968). Unknown if specimens are in collections. Notes: Additional records reported in Tipton and Mendez (1968). QUERÉTARO: 6.24 km W of Amealco; $1 \mathrm{~km} \mathrm{~S}$ of Pinal de Amoles: Peromyscus levipes. Camargo, Maguey Verde: P. difficilis (Acosta 2003). Landa de Matamoros, El Pemoche: Handleyomys chapmani (recorded as Oryzomys chapmani huastecae), Reithrodontomys mexicanus. Pinal de Amoles, $1.2 \mathrm{~km} \mathrm{~S}$ of Pinal de Amoles: Netoma mexicana, P. boylii (Acosta et al. 2008). Specimens in collections: MZFC. TLAXCALA: La Malinche: Neotomodon alstoni, Peromyscus difficilis, P. gratus, P. leucopus, P. maniculatus, P. melanotis, Reithrodontomys fulvescens (Aguilar-Montiel et al. 2018). Españita, 3 km NW of Vicente Guerrero: P. gratus. Huamantla, La Malinche (Caseta \#4): N. alstoni (recorded as Peromyscus alstoni), P. gratus, P. melanotis (Acosta et al. 2008). Specimens in collections: MZFC. VERACRUZ: Cofre de Perote: Reithrodontomys sp. (AyalaBarajas et al. 1988). Specimens in collections: MZFC.

\section{Plusaetis soberoni (Barrera, 1958)}

GUERRERO: Omiltemi: Peromyscus sp. (Barrera 1958). Atoyac de Ávarez, Puerto del Galo-Paraíso Highway, km 14: Heteromys pictus. General Heliodoro Castillo, El Iris: Handleyomys alfaroi (recorded as Oryzomys alfaroi), Megadontomys thomasi, Oryzomys sp. Chilpancingo de los Bravo, Omiltemi: M. thomasi, Peromyscus levipes, P. maniculatus, Peromyscus sp. $0.3 \mathrm{~km} \mathrm{~N}$ of Omiltemi: P. maniculatus. 2.5 km E of Omiltemi: $M$. thomasi. Cañada de Agua Fría: $P$. boylii. Omiltemi, Cañada Potrerillos: P. megalops (Acosta et al. 2008). Agua Fría, Yextla, 22 km SW: P. megalops. Camotla, Chichihualco: Osgoodomys banderanus (recorded as Peromyscus banderanus vicinior). $1 \mathrm{mi}$ SW of Omiltemi, Peromyscus sp. (Ayala-Barajas et al. 1988). Specimens in collections: MZFC. Note: P. boylii is not distributed in Guerrero according to Ceballos (2014). Note: Oryzomys sp. was recorded in the original literature but may represent Handleyomys sp. OAXACA: San Juan Lachao, $10 \mathrm{~km}$ S of San Juan Lachao: Oryzomys sp. (Ayala-Barajas et al. 1988). Ixtlán de Juárez, 1.5 km SE of Santa María Yavesía: Oligoryzomys fulvescens. Ixtlán de Juárez, 4.5 km SE of Santa María Yavesía, Peromyscus mexicanus. Ixtlán de Juárez, 8.76 km SE of Santa María Yavesía: P. difficilis. Ixtlán de Juárez, 6.5 km E-SE of Santa María Yavesía, P. aztecus, P. difficilis, P. melanocarpus, P. mexicanus (Acosta et al. 2008). Specimens in collections: MZFC. Note: Oryzomys sp. was recorded in the original literature but may represent Handleyomys sp.

\section{Plusaetis sp.}

CIUDAD DE MÉXICO: Cuajimalpa de Morelos, $1 \mathrm{~km}$ del Potrillo, Parque Nacional Desierto de los Leones: Peromyscus difficilis. El Pantano, Parque Nacional Desierto de los Leones: P. maniculatus (Acosta et al. 2008). Specimens in collections: MZFC. GUERRERO: San Miguel Totolopan, Puerto del Gallo: Peromyscus sp. (Acosta et al. 2008). Speci- 
mens in collections: MZFC. OAXACA: Ixtlán de Juárez, 4.5 km SE of Santa María Yavesía: Peromyscus mexicanus. Ixtlán de Juárez, 6.5 km E-SE of Santa María Yavesía; Ixtlán de Juárez, 8.75 km SE of Santa María Yavesía: P. difficilis (Acosta et al. 2008). Specimens in collections: MZFC. QUERÉTARO: Peñamiller, Camargo; Peñamiller, Maguey Verde: Peromyscus difficilis. Pinal de Amoles, $1.2 \mathrm{~km}$ S of Pinal de Amoles: $P$. boylii (Acosta et al. 2008). Specimens in collections: MZFC. VERACRUZ: Ixhuatlancillo, Rancho La Pala: Peromyscus sp. (Acosta et al. 2008). Specimens in collections: MZFC. TLAXCALA: Españita, 3 km NW of Vicente Guerrero: Reithrodontomys megalotis, Reithrodontomys sp. (Acosta et al. 2008). Specimens in collections: MZFC.

\section{Thrassis aridis Prince, 1944}

CHIHUAHUA: Janos Biosphere Reserve: Onychomys leucogaster, Dipodomys spectabilis (Fernández-González et al. 2016). No specimens in collections. $35 \mathrm{mi} S$ Ciudad Juárez: Onychomys leucogaster (Traub and Hoff 1951). Unknown if specimens are in collections. DURANGO: Hidalgo, $4 \mathrm{~km}$ S-SE of la Zarca: Dipodomys nelsoni (Fernández and Acosta 2005; Acosta et al. 2008). Specimens in collections: MZFC. Note: Acosta et al. (2008) lists this species as Thrassis aridis campestris.

\section{Thrassis bacchi (Rothschild, 1905)}

CHIHUAHUA: 35 mi S of Ciudad Juárez: Onychomys leucogaster (Traub and Hoff 1951). Unknown if specimens are in collections. Note: Stark (1970) reports additional records from Chihuahua and Guerrero.

\section{Thrassis fotus (Jordan, 1925)}

TLAXCALA: Calpulalpan: Peromyscus difficilis (Barrera 1953). 5 mi E of Calpulalpan: P. difficilis (Ayala-Barajas et al. 1988). Specimens in collections: MZFC. Note: Stark (1970) reports additional records from Chihuahua, Tamaulipas, and Tlaxcala.

\section{Dactylopsyllinae Jordan, 1929 \\ Foxella ignota (Baker, 1895)}

NUEVO LEÓN: Cerro Potosí: Peromyscus melanotis (Tipton and Mendez 1968). Unknown if specimens are in collections. SAN LUIS POTOSÍ: El Salto: Sigmodon hispidus (Hubbard 1958). Specimens in collections: BMNH. Note: S. hispidus is not distributed in San Luis Potosí according to Ceballos (2014). A possible alternative host includes S. leucotis (Ceballos 2014). Note: Hubbard (1958) also describes this association as likely accidental as Foxella normally parasitizes pocket gophers.

Ctenophthalmidae Rothschild, 1915

Anomiopsyllinae Baker, 1905

Anomiopsyllus durangoensis Holland, 1965
DURANGO: 8 km W Durango: Peromyscus sp. nest ( $\mathrm{Hol}-$ land 1965). Specimens in collections: CNC. NUEVO LEÓN: Cerro Potosí: Neotoma leucodon (recorded as N. albigula; Holland 1965). Specimens in collections: CNC.

Anomiopsyllus nidiophilus Tipton and Méndez, 1968

DURANGO: 8 km W of Durango: Peromyscus sp. (Tipton and Mendez 1968). Specimens in collections: CNC. NUEVO LEÓN: Cerro Potosí: Neotoma leucodon (recorded as $N$. albigula leucodon; Tipton and Mendez 1968). Specimens in collections: BMNH, BYU, CNC, MZFC, USNM (with additional specimens at the Bishop Museum, GML, and RML).

Anomiopsyllus novomexicanensis Williams and Hoff, 1951

TLAXCALA: El Carmen Tequexquitla, El Piñonal: Peromyscus sp. (Acosta et al. 2008). Specimens in collections: MZFC.

Anomiopsyllus nudatus hiemalis Eads and Menzies, 1948

COAHUILA: Sabinas: Neotoma micropus, Neotoma sp. nest (Vargas 1951e; Barnes et al. 1977; Ayala-Barajas et al. 1988). Specimens in collections: MZFC.

Anomiopsyllus nudatus mexicanus Holland, 1965

CHIHUAHUA: Mesa del Huracán: Neotoma sp. nest ( land 1965). Specimens in collections: CNC.

Anomiopsyllus oaxacae Barnes, 1965

OAXACA: 2 mi SE of Matatlán: Baiomys musculus (Barnes 1965). Specimens in collections: USNM.

Anomiopsyllus perotensis Acosta and Fernández, 2009

PUEBLA: Multiple localities: Peromyscus difficilis, Dipodomys phillipsii (Acosta and Fernández 2015). Specimens in collections: MZFC. VERACRUZ: near El Frijol Colorado, Mpio. of Perote: Neotoma nelsoni (Acosta and Fernández 2009). Specimens in collections: MZFC.

\section{Anomiopsyllus sinuatus Holland, 1965}

DURANGO: 48 km W of Durango: Peromyscus sp. nest (Holland 1965). Specimens in collections: CNC. $30 \mathrm{mi} \mathrm{W}$ of Durango: Peromyscus sp. nest (Ayala-Barajas et al. 1988). Specimens in collections: MZFC. HIDALGO: Xoxafí: Peromyscus difficilis (Ayala-Barajas et al. 1988). Specimens in collections: MZFC. PUEBLA: Multiple localities: Peromyscus difficilis (Acosta and Fernández 2015). Specimens in collections: MZFC. VERACRUZ: Perote, $3 \mathrm{~km}$ S of El Frijol Colorado: Peromyscus difficilis (Acosta and Fernández 2015). Specimens in collections: MZFC.

\section{Anomiopsyllus sp.}

CHIHUAHUA: Vado de Fusiles: Peromyscus manicula- 
tus (Traub and Hoff 1951). Specimens are in collections: Unknown, possibly AMNH. CIUDAD DE MÉXICO: San Ángel: Neotoma sp. (Ayala-Barajas et al. 1988). Specimens in collections: MZFC. GUERRERO: Camotla, Mpio. de Chichihualco: Osgoodomys banderanus (recorded as Peromyscus banderanus vicinior; Ayala-Barajas et al. 1988). Specimens in collections: MZFC.

\section{Conorhinopsylla sp.}

ESTADO DE MÉXICO: Popocatépetl: Neotoma mexicana (Barrera 1968). Popocatépetl, Mirador del Poeta: N. mexicana (Ayala-Barajas et al. 1988). Specimens in collections: MZFC.

\section{Stenistomera alpina (Baker, 1895)}

VERACRUZ: Near El Frijol Colorado, Mpio. of Perote: Neotoma nelsoni (Acosta and Fernández 2009). Specimens in collections: MZFC.

\section{Ctenophthalminae Rothschild, 1915}

Ctenophthalmus (Alloctenus) caballeroi Barrera and Machado, 1960

CIUDAD DE MÉXICO: Cerro de la Marquesa; El Zarco: Microtus mexicanus (Barrera and Machado 1960). El Zarco: Microtus sp. nest (Morrone et al. 2000). Specimens in collections: IBUNAM. Popocatépetl: M. mexicanus, Peromyscus difficilis, Reithrodontomys sp. (Barrera 1968; Morrone et al. 2000). Specimens in collections: MZFC. ESTADO DE MÉXICO: Salazar: Microtus mexicanus (Machado-A. 1960). Specimens in collections: MZFC. Popocatépetl: M. mexicanus, Peromyscus difficilis, Reithrodontomys chrysopsis, Reithrodontomys sp. (Barrera 1968; Morrone et al. 2000). Specimens in collections: MZFC.

Ctenophthalmus (Alloctenus) expansus Traub, 1950

MICHOACÁN: Monte Tancítaro: Reithrodonomys chrysopsis (Traub 1950). Specimens in collections: FMNH.

\section{Ctenophthalmus (Alloctenus) haagi Traub, 1950}

COLIMA: Microtus sp. (Morrone et al. 2000). Specimens in collections: MZFC. CIUDAD DE MÉXICO: San Juan de Aragón: Microtus mexicanus (Barrera 1953). El Zarco: Microtus sp. nest, M. mexicanus (Barrera 1953; Hopkins and Rothschild 1966; Ayala-Barajas et al. 1988). Bosque de Chapultepec: M. mexicanus (Morrone et al. 2000). Churubusco: M. mexicanus, Microtus sp. Bosque de Chapultepec; San Andrés Tetepilco: M. mexicanus (Ayala-Barajas et al. 1988). Specimens in collections: MZFC. DURANGO: $10 \mathrm{mi} \mathrm{W}$ of El Salto: Microtus mexicanus (Morrone et al. 2000). Specimens in collections: MZFC. ESTADO DE MÉXICO: Slopes of Volcano Popocatépetl: Peromyscus melanotis, Microtus mexicanus (Barrera 1953, Ayala-Barajas et al. 1988). Popocatépetl: M. mexicanus. (Ayala-Barajas et al. 1988). La Marquesa: M. mexicanus (Morrone et al. 2000). Specimens in collections: MZFC. Guerrero: Agua Fría, $22 \mathrm{~km}$ SW of Yextla; $1 \mathrm{mi}$ SW of Omiltemi: Peromyscus sp. (Morrone et al. 2000). Specimens in collections: MZFC. Hidalgo: Singuilucan: Microtus mexicanus (Ayala-Barajas et al. 1988; Morrone et al. 2000). Sierra Madre Oriental: M. mexicanus (Gutiérrez-Velázquez and Acosta 2004). Specimens in collections: MZFC. JALISCO: Nevado de Colima: Microtus mexicanus (Ayala-Barajas et al. 1988). Specimens in collections: MZFC. MICHOACÁN: Tancítaro, Mt. Tancítaro: Microtus mexicanus, Microtus sp., Peromyscus sp. (Traub 1950; Hopkins and Rothschild 1966; Morrone et al. 2000). Specimens in collections: BMNH (BMNH 1942.29), FMNH, NMNH. MORELOS: Atzompa: Peromyscus hylocetes. Cuautepetl-Huitzilac; Huitzilac; Lagunas de Zempoala: Microtus mexicanus (Ayala-Barajas et al. 1988). Mpio. de Huitzilac, Ojo de Agua de Oclatzingo: Microtus mexicanus (Barrera 1954a). Specimens in collections: MZFC. OAXACA: San Juan Atepec, Tuxtepec-Oaxaca Highway, km 91, road to San Isidro: Megadontomys thomasi, Microtus oaxacensis, Handleyomys chapmani (recorded as Oryzomys chapmani), Oryzomys sp., Peromyscus melanocarpus, P. mexicanus, Peromyscus sp. Santiago Comaltepec, El Suspiro, km 87, Tuxtepec-Oaxaca Highway: M. thomasi, H. alfaroi (recorded as O. alfaroi), H. chapmani (recorded as O. chapmani), Oryzomys sp. P. melanocarpus, Peromyscus sp. (Morrone et al. 2000). Ixtlán de Juárez, $4 \mathrm{~km}$ SE of Santa María Yavesía: Microtus sp. Ixtlán de Juárez, $6.5 \mathrm{~km}$ E-SE of Santa María Yavesía: Microtus mexicanus, Orzomys sp., Peromyscus difficilis, P. melanocarpus, P. mexicanus. Ixtlán de Juárez, 8.75 km SE of Santa María Yavesía: P. difficilis. Santiago Comaltepec, Tuxtepec-Oaxaca Highway, km 79.5, La Esperanza: H. alfaroi (recorded as O. alfaroi; Acosta et al. 2008). Specimens in collections: MZFC. Note: M. thomasi is not distributed in Oaxaca according to Ceballos (2014). These specimens are likely M. cryophilus or M. nelsoni. Note: Oryzomys sp. was recorded in the original literature but may represent Handleyomys sp.

Ctenophthalmus (Alloctenus) micropus Traub, 1950

COAHUILA: Sabinas: Neotoma micropus (Traub 1950). Specimens in collections: USNM. CIUDAD DE MÉXICO: El Zarco; Bosque de Chapultepec; Río de Churubusco; Las Cruces; Las Pilas; San Cayetano México: Microtus mexicanus (Machado-A. 1960; Sandoval et al. 1962). Specimens in collections: MZFC. Parque Nacional Insurgente Miguel Hidalgo y Costilla: M. mexicanus, Peromyscus mexicanus, Reithrodontomys megalotis (Méndez-L. 1974). Unknown if specimens are in collections. Churubusco: M. mexicanus (Ayala-Barajas et al. 1988; Morrone et al. 2000). Iztaccíhuatl: M. mexicanus (Morrone et al. 2000). Specimens in collections: MZFC. Note: P. mexicanus is not distributed in Ciudad de México according to Ceballos (2014). DURANGO: $10 \mathrm{mi} \mathrm{W}$ of El Salto: Microtus sp. nest (Morrone et al. 2000). Specimens in collections: MZFC. ESTADO DE MÉXICO: Popocatépetl: Microtus mexicanus, Reithrodontomys chrysopsis (Barrera 1968). Iztaccíhuatl: M. mexicanus (Morrone et al. 2000). Mt. 
Iztaccíhuatl; Vert. Occidental: M. mexicanus (Ayala-Barajas et al. 1988). Specimens in collections: MZFC. HIDALGO: Tlanchinol: Peromyscus furvus (Salceda-Sánchez and Hastriter 2006). Specimens in collections: CAIM, InDRE. Sierra Madre Oriental: $P$. furvus (Gutiérrez-Velázquez and Acosta 2004). Specimens in collections: MZFC. MICHOACÁN: 12 mi W of Hidalgo: Microtus mexicanus (Morrone et al. 2000). Specimens in collections: NMNH. MORELOS: Derrame del Chichinautzin: Peromyscus difficilis (Pérez-Ortiz 1976; AyalaBarajas et al. 1988). Chichinautzin: P. difficilis (Morrone et al. 2000). Specimens in collections: MZFC. OAXACA: Ixtlán de Juárez, $6.5 \mathrm{~km}$ E-SE of Santa María Yavesía: Microtus mexicanus (Acosta et al. 2008). Specimens in collections: MZFC. PUEBLA: San Juan Tetla, Mpio. de Chiautzingo: Microtus mexicanus, Neotomodon alstoni, Peromyscus melanotis (Ramírez 1982). Unknown if specimens are in collections. QUERÉTARO: $2.5 \mathrm{~km}$ NW of Santa Inés; $1 \mathrm{~km}$ SW of Pinal de Amoles; Santa Inés; 2.8 km NW of Santa Inés: Peromyscus furvus. $1 \mathrm{~km}$ NW of Santa Inés: P. levipes (recorded as $P$. boylii levipes; Morrone et al. 2000; Acosta 2003). Specimens in collections: MZFC. ORIENTAL BASIN: Multiple localities in Puebla, Tlaxcala, and Veracruz: Peromyscus furvus (Acosta and Fernández 2015). Specimens in collections: MZFC. Note: $P$. furvus is not distributed in Tlaxcala according to Ceballos (2014).

\section{Ctenophthalmus (Alloctenus) pseudagyrtes Baker, 1904}

GUERRERO: General Heliodoro Castillo, El Iris: Peromyscus megalops. San Miguel Totolapan, Puerto del Gallo: Megadontomys thomasi, P. megalops. Leonardo Bravo, Carrizal del Bravo: Peromyscus sp. (Acosta et al. 2008). Specimens in collections: MZFC. NUEVO LEÓN: Cerro Potosí: Microtus mexicanus, Peromyscus difficilis, P. melanotis, Peromyscus sp. (Tipton and Mendez 1968; Morrone et al. 2000). Specimens in collections: NMNH. OAXACA: Ixtlán de Juárez, 4 km SE of Santa María Yavesía: Mictrotus mexicanus, Microtus sp. Ixtlán de Juárez, 6.5 km E-SE of Santa María Yavesía: Peromyscus melanocarpus (Acosta et al. 2008). Specimens in collections: MZFC. QUERÉTARO: El Pemoche; 2.8 km NW of Santa Inés: Peromyscus furvus. $1 \mathrm{~km}$ NW of Santa Inés: P. levipes (Acosta 2003). Landa de Matamoros, El Pemoche: P. furvus (Acosta et al. 2008). Specimens in collections: MZFC. Veracruz: El Cedeño, Xalapa; 1/2 mi NE of Las Minas, approximately 16 mi NE of Perote: Peromyscus sp. (Morrone et al. 2000). Specimens in collections: MZFC. SIERRA MADRE ORIENTAL: Multiple localities in Hidalgo, Querétaro, Tamaulipas: Peromyscus furvus, P. levipes (Gutiérrez-Velázquez and Acosta 2004). Specimens in collections: MZFC. Note: P. furvus is not distributed in Tamaulipas according to Ceballos (2014).

\section{Ctenophthalmus (Alloctenus) tecpin Morrone, Acosta, and Gutiérrez, 2000}

GUERRERO: Atoyac de Álvarez, 3 km S of Puerto del Gallo; Chilpancingo de los Bravo, Omiltemi, Cañada de Agua Fría: Megadontomys thomasi. Chilpancingo de los Bravo, 2.5 km E of Omiltemi: Peromyscus megalops. Chilpancingo de los Bravo, $4 \mathrm{~km}$ N of Omiltemi: M. thomasi, P. levipes. San Miguel Totolapan, Estación Toro Muerto: Peromyscus sp. San Miguel Totolapan, Puerto del Gallo: M. thomasi, Oryzomys sp., P. boylii, P. megalops, Peromyscus sp. (Acosta et al. 2008). Specimens in collections: MZFC. Note: P. boylii is not distributed in Guerrero according to Ceballos (2014). Note: Oryzomys sp. was recorded in the original literature but may represent Handleyomys sp. HIDALGO: Tlanchinol: Peromyscus furvus, Handleyomys rostratus (recorded as Oryzomys melanotis rostratus; Salceda-Sánchez and Hastriter 2006). Specimens in collections: CAIM, InDRE. Tenango de Doria, El Potrero: P. furvus (Acosta et al. 2008). Specimens in collections: MZFC. NUEVO LEÓN: El Potosí: Microtus sp., Peromyscus difficilis (Morrone et al. 2000; Salceda-Sánchez and Hastriter 2006). Specimens in collections: CAIM, InDRE, MZFC. OAXACA: Ixtlán de Juárez, 6.5 km E-SE of Santa María; Ixtlán de Juárez, 8.75 km SE of Santa María Yavesía: Peromyscus difficilis (Acosta et al. 2008). Specimens in collections: MZFC. QUERÉTARO: El Pemoche, Landa de Matamoros: Handleyomys chapmani (recorded as Oryzomys chapmani), Peromyscus furvus (Acosta 2003; Acosta et al. 2008). Specimens in collections: MZFC. TLAXCALA: Huamantla, La Malinche: Microtus mexicanus, Neotomodon alstoni, Peromyscus difficilis, P. gratus, P. maniculatus, Reithrodontomys chrysopsis, $R$. megalotis, Heteromys irroratus (Acosta and Fernández 2006; Acosta et al. 2008; Aguilar-Montiel et al. 2018). Specimens in collections: MZFC. VERACRUZ: Ixhuatlancillo, Rancho La Pala: Peromyscus sp. (Acosta et al. 2008). Specimens in collections: MZFC.

\section{Ctenophthalmus sp.}

ESTADO DE MÉXICO: La Marquesa: Microtus mexicanus. Río Frío: Peromyscus sp. Popocatépetl, S. Pedro Tlanixco (Nexapa): Reithrodontomys sp. nest. Popocatépetl, San Pedro Nexapa: Peromyscus difficilis, Reithrodontomys sp. Popocatépetl, 5 km E of San Pedro Nexapa; Popocatépetl, Mirador del Poeta: M. mexicanus (Ayala-Barajas et al. 1988). Specimens in collections: MZFC. DURANGO: $10 \mathrm{mi}$ W of El Salto: Microtus mexicanus (Ayala-Barajas et al. 1988). Specimens in collections: MZFC. GUERRERO: Agua Fría, 22 km SW of Yextla; Omiltemi; 1 m SW of Omiltemi: Peromyscus sp. (Ayala-Barajas et al. 1988). Specimens in collections: MZFC. NUEVO LEÓN: El Potosí: Microtus sp. El Potosí, 18 km $\mathrm{N}$ of Galeana: Peromyscus difficilis (Ayala-Barajas et al. 1988). Specimens in collections: MZFC. OAXACA: Ixtlán de Juárez, 6.5 km E-SE of Santa María: Peromyscus melanocarpus, P. gratus (recorded as P. truei). Ixtlán de Juárez, $8.75 \mathrm{~km}$ SE of Santa María Yavesía: P. difficilis (Acosta et al. 2008). Specimens in collections: MZFC. VERACRUZ: El Cedeño, Jalapa; $1 \frac{1}{2} \mathrm{mi}$ NE of Las Minas; $1 \frac{1}{2}$ mi NE of Las Minas, aprox. 16 mi NE Perote: Peromyscus sp. (Ayala-Barajas et al. 1988). Specimens in collections: MZFC. SIERRA MADRE ORIENTAL: Multiple localities in Hidalgo, Nuevo León, Puebla, Querétaro, and Veracruz: Peromyscus difficilis, Peromyscus sp. (Gutiérrez-Velázquez and Acosta 2004). Specimens in collections: MZFC. 
Neopsyllinae Oudemans, 1909 Catallagia sp.

ESTADO DE MÉXICO: Popocatépetl: Microtus mexicanus (Barrera 1968). Specimens in collections: MZFC.

Epitedia wenmanni (Rothschild, 1904)

NUEVO LEÓN: Cerro Potosí: Peromyscus melanotis, $P$. difficilis, Peromyscus sp., Microtus mexicanus (Tipton and Mendez 1968). Unknown if specimens are in collections. El Potosí: P. maniculatus. El Potosí, 18 km N of Galeana: P. difficilis, P. maniculatus (Ayala-Barajas et al. 1988). Sierra Madre Oriental: P. maniculatus (Gutiérrez-Velázquez and Acosta 2004). Specimens in collections: MZFC.

\section{Epitedia sp.}

OAXACA: Ixtlán de Juárez, 4.5 km SE of Santa María Yavesía: Peromyscus sp. (Acosta et al. 2008). Specimens in collections: MZFC.

\section{Meringis altipecten Traub and Hoff, 1951}

CHIHUAHUA: Janos Biosphere Reserve: Onychomys arenicola, O. leucogaster, Peromyscus maniculatus, Dipodomys merriami, D. spectabilis (Fernández-González et al. 2016). No specimens in collections. Vado de Fusiles: D. merriami (Traub and Hoff 1951). Specimens in collections: AMNH. DURANGO: Hidalgo, $4 \mathrm{~km}$ S-SE of la Zarca: Onychomys torridus (Acosta et al. 2006; 2008). Specimens in collections: MZFC. Note: O. torridus is not distributed in Durango according to Ceballos (2014). HIDALGO: Xaxafi: Dipodomys sp. (Ayala-Barajas et al. 1988). Specimens in collections: MZFC. PUEBLA: $2 \mathrm{~km}$ W of Atenco de Aljojuca: Peromyscus maniculatus, Dipodomys phillipsii (Barrera 1954b). $2 \mathrm{~km} \mathrm{~W}$ of Aljojoca: D. phillipsi (Ayala-Barajas et al. 1988). $2 \mathrm{~km} \mathrm{~W}$ Guadalupe Victoria, Mpio. de Guadalupe Victoria: P. maniculatus, Heteromys irroratus (Falcón-Ordaz et al. 2012). Specimens in collections: MZFC. QUERÉTARO: Tolimán, Tolimán: Heteromys irroratus, Heteromys sp. (Acosta 2003; Acosta et al. 2008). Specimens in collections: MZFC. SAN LUIS POTOSÍ: $12 \mathrm{~km}$ SE of Sta. Ma del Río: Dipdomys sp. (Ayala-Barajas et al. 1988). Specimens in collections: MZFC. ORIENTAL BASIN: Multiple localities in Puebla, Tlaxcala, and Veracruz: Peromyscus maniculatus, Peromyscus sp., Dipodomys phillipsii (Acosta and Fernández 2015). Specimens in collections: MZFC. VERACRUZ: 3 km S El Frijol Colorado, Mpio. de Perote: Peromyscus maniculatus, Dipodomys phillipsii (Falcón-Ordaz et al. 2012). Specimens in collections: MZFC.

\section{Meringis arachis (Jordan, 1929)}

CHIHUAHUA: Janos Biosphere Reserve: Onychomys arenicola, O. leucogaster, Dipodomys merriami, D. spectabilis (Fernández-González et al. 2016). No specimens in collections. Majalca Rd. Mex: Dipodomys sp. (AyalaBarajas et al. 1988). Specimens in collections: MZFC.
$1.5 \mathrm{mi}$ S. of México-USA border near Columbus, New México, USA: Dipodomys spectabilis. Near Columbus, New México: Kangaroo rat (Dipodomys sp.) or Peromyscus sp. (Hopkins and Rothschild 1962). Specimens in collections: BMNH. DURANGO: Hidalgo, $4 \mathrm{~km} \mathrm{S-SE} \mathrm{of}$ la Zarca: Perognathus flavus (Acosta et al. 2006; 2008). Dipodomys nelsoni (Fernández and Acosta 2005; Acosta et al. 2008). Specimens in collections: MZFC. OAXACA: Ixtlán de Juárez, 8.75 km SE of Santa María Yavesía: Peromyscus difficilis (Acosta et al. 2008). Specimens in collections: MZFC. QUERÉTARO: Tolimán, El Derramadero: Peromyscus pectoralis (Acosta et al. 2008). Specimens in collections: MZFC.

\section{Meringis cummingi (C. Fox, 1926)}

BAJA CALIFORNIA: Rancho El Metate, S. Juan de Dios Matomi: Dipodomys sp. (Ayala-Barajas et al. 1988). Specimens in collections: MZFC.

\section{Meringis dipodomys Kohls, 1938}

SONORA: $11 \mathrm{~km}$ NE of Puerto Peñasco; $60 \mathrm{~km}$ SW of Caborca (Km 2450): Dipodomys sp. $12 \mathrm{~km} \mathrm{NE}$ of Puerto Peñasco: Onychomys sp. (Ayala-Barajas et al. 1988). Specimens in collections: MZFC.

\section{Meringis parkeri Jordan, 1937}

CHIHUAHUA: Janos Biosphere Reserve: Onychomys arenicola, O. leucogaster, Dipodomys merriami (FernándezGonzález et al. 2016). No specimens in collections.

\section{Meringis sp.}

BAJA CALIFORNIA: Rancho El Metate, S. Juan de Dios Matomi: Dipodomys sp. (Ayala-Barajas et al. 1988). Specimens in collections: MZFC. SAN LUIS POTOSÍ: $1 \mathrm{~km} \mathrm{E}$ of Huizache: Onychomys sp. 5 km SW of Nuñez: Perognathus sp. (Ayala-Barajas et al. 1988). Specimens in collections: MZFC.

\section{Phalacropsylla nivalis Barrera and Traub, 1967}

ESTADO DE MÉXICO: Popocatépetl, $300 \mathrm{~m}$ SW of volcán Tlamaca: Neotoma mexicana (Acosta and Hastriter 2017). Mirador del Poeta, north slope of Popocatépetl: N. mexicana, Peromyscus melanotis; $9 \mathrm{~km}$ W Río Frío: N. mexicana (Barrera and Traub 1967). Río Frío: N. mexicana. Popocatépetl, Mirador del Poeta: $P$. melanotis (Ayala-Barajas et al. 1988; Acosta and Hastriter 2017). Specimens in collections: MZFC.

\section{Strepsylla davisae Traub and Johnson, 1952}

DURANGO: $5 \mathrm{mi} \mathrm{W}$ of El Salto: Peromyscus sp. (Traub and Johnson 1952c). Specimens in collections: AMNH. 11.2 km NE of Revolcaderos: Peromyscus sp. (Acosta 2011). Specimens in collections: CMNH, USNM. OAXACA: Ixtlán de 
Juárez, 8.75 km SE of Santa María Yavesía: Peromyscus difficilis (Acosta et al. 2008). Specimens in collections: MZFC.

\section{Strepsylla fautini Traub, 1950}

MICHOACÁN: Tancítaro: Peromyscus hylocetes (Traub 1950). Mount Tancítaro: P. hylocetes (Acosta 2011). Specimens in collections: FMNH.

\section{Strepsylla ixtlanensis Acosta, 2010}

OAXACA: Ixtlán, 8.75 km SE of Santa María Yavesia: Peromyscus difficilis (Acosta 2011). Specimens in collections: MZFC.

\section{Strepsylla longicauda Acosta, 2010}

DURANGO: 804 m SE of Buenos Aires: Peromyscus sp. (Acosta 2011). Specimens in collections: CMNH.

\section{Strepsylla machadoi Barrera and Traub, 1963}

GUERRERO: Puerto Chico, Mpio. De Leonardo Bravo, Omiltemi: Peromyscus sp. (Barrera and Traub 1963). Ojo de Agua de Puerto Chico, Mpio. de Chichihualco: Osgoodomys banderanus (recorded as Peromyscus banderanus). Agua Fría, 22 km SW of Yextla; 5 mi SW of Omiltemi: Peromyscus sp. (Ayala-Barajas et al. 1988). Chilpancingo de los Bravo, $4 \mathrm{~km} \mathrm{~N}$ of Omiltemi: P. megalops, Peromyscus sp. Chilpancingo de los Bravo, Omiltemi, Cañada de Agua Fría: Megadontomys thomasi. General Heliodoro Castillo, El Iris: P. megalops. San Miguel Totolapan, Estación Toro Muerto; Leonardo Bravo, Carrizal del Bravo: Peromyscus sp. (Acosta et al. 2008). Specimens in collections: MZFC. Chichihualco, Puerto Chico, Camotla: Osgoodomys banderanus. Los Retrocesos: Handleyomys alfaroi (recorded as Orzyomys alfaroi). Toro Muerto, San Miguel Totolapan; Leonardo Bravo, Carrizal de Bravo; km 18, Puerto del Gallo - El Paraíso Highway, La Golondrina; Nueva Delhi; 1.6 km SW of Omiltemi; Agua Fria, 22 km SW of Yextla: Peromyscus sp. Km 14 Puerto del Gallo - El Paraíso Highway; Chilpancingo, Omiltemi, Cañada de agua fría: M. thomasi. Tlacotepec, Puerto del Gallo: $M$. thomasi, P. levipes, P. megalops, Peromyscus sp. Tlacotepec, El Iris, $7 \mathrm{~km} \mathrm{~W}$ of Puerto del Gallo; Chilpancingo, $4 \mathrm{~km} \mathrm{~N}$ of Omiltemi: P. megalops, Peromyscus sp. Tlacotepec, El Iris: M. thomasi, P. megalops, Peromyscus sp. La Golondrina: P. megalops (Acosta 2011). Specimens in collections: BMNH, CMNH, MZFC, USNM.

\section{Strepsylla mina Traub, 1950}

CIUDAD DE MÉXICO: El Guarda: Neotomodon alstoni, Peromyscus hylocetes. Slopes of volcán Popocatépetl: $P$. hylocetes, P. melanotis. El Zarco: P. maniculatus. La Venta: P. gratus (recorded as P. truei), P. hylocetes (Barrera 1953). El Zarco: P. hylocetes, P. maniculatus. La Venta: P. gratus (recorded as P. truei), P. hylocetes. $2 \mathrm{~km}$ NE of Ajusco; Contreras: Peromyscus sp. Parres: N. alstoni, Peromyscus sp.
Cuajimalpa de Morelos, Cabeza del Toro, Parque Nacional Desierto de los Leones: P. maniculatus. Cuajimalpa 1 km del Paraje Cruz Blanca, on firebreaks, Parque Nacional Desierto de los Leones: P. difficilis (Ayala-Barajas et al. 1988; Acosta et al. 2008; Acosta 2011). Specimens in collections: MZFC. Parque Nacional Insurgente Miguel Hidalgo y Costilla: Microtus mexicanus, P. maniculatus (Méndez-L. 1974). Unknown if specimens are in collections. ESTADO DE MÉXICO: Popocatépetl: Neotomodon alsonti, Peromyscus melanotis, P. difficilis, P. maniculatus, P. hylocetes, Reithrodontomys chrysopsis, R. megalotis (Barrera 1953; 1968; Ayala-Barajas et al. 1988; Acosta 2011). Specimens in collections: MZFC. 5 km E of San Pedro Nexapa: Microtus mexicanus, P. difficilis, P. maniculatus, Peromyscus sp., Reithrodontomys sp. Popocatépetl, San Pedro Nexapa: $P$. difficilis, P. maniculatus, Reithrodontomys sp., Reithrodontomys sp. nest (Ayala-Barajas et al. 1988; Acosta 2011). Lagunas de Zempoala, near Ojotongo: P. maniculatus, Peromyscus sp. Lagunas de Zempoala, near Morelos; Popocatépetl, $5.5 \mathrm{~km} \mathrm{~S}$ of San Pedro Nexapa: Peromyscus sp. Lagunas de Zempoala, La Cachucha: P. maniculatus (Acosta 2011). Specimens in collections: CMNH, MZFC. GUERRERO: Chilpancingo de los Bravo, Omiltemi: Peromyscus megalops (Acosta et al. 2008). Specimens in collections: MZFC. HIDALGO: El Chico: Peromyscus maniculatus (Ayala-Barajas et al. 1988; Acosta 2011). Specimens in collections: MZFC. JALISCO: Nevado de Colima: Microtus mexicanus, Microtus sp., Peromyscus sp. (Ayala-Barajas et al. 1988; Acosta 2011). Nevado de Colima near la Joya: Microtus sp., Peromyscus hylocetes, P. melanotis, Peromyscus sp. Nevado de Colima, $6.4 \mathrm{~km}$ W of La Joya: Microtus sp., $P$. melanotis (Acosta 2011). Specimens in collections: $\mathrm{CMNH}$, MWH, MZFC, USNM. MICHOACÁN: Tancítaro: Microtus mexicanus, Neotomodon alstoni, Peromyscus melanotis (Traub 1950; Hopkins and Rothschild 1962). Tancítaro, Mt. Tancítaro: M. mexicanus, P. melanotis (Acosta 2011). Specimens in collections: BMNH, FMNH, USNM. MORELOS: Km 42, highwayCiudad de México to Cuernavaca: Peromyscus hylocetes (Ayala-Barajas et al. 1988). Km 14, highway Tres Cumbres-Zempoala: Peromyscus maniculatus (Barrera 1954a). Specimens in collections: MZFC. PUEBLA: San Juan Tetla, Mpio. de Chiautzingo: Microtus mexicanus, Peromyscus maniculatus (Ramírez 1982). Unknown if specimens are in collections. QUERÉTARO: $1 \mathrm{~km}$ S of Pinal de Amoles: Peromyscus levipes (Acosta 2003; Acosta 2011). Specimens in collections: CMNH, MZFC. TLAXCALA: Calpulalpan: Peromyscus difficilis (Barrera 1953). Specimens in collections: MZFC. SIERRA MADRE ORIENTAL: Multiple localities in Hidalgo, Querétaro, Veracruz: Peromyscus sp. (Gutiérrez-Velázquez and Acosta 2004). Specimens in collections: MZFC.

\section{Strepsylla queretana Acosta, 2010}

QUERÉTARO: Maguey Verde: Peromyscus difficilis Acosta 2011). Specimens in collections: MZFC. 
Strepsylla schmidti Traub and Barrera, 1955

CHIAPAS: 17 km NW of Teopisca: Peromyscus beatae, $P$. boylii (Traub and Barrera 1955; Acosta 2011). Tzontehuitz: P. beatae (Acosta 2011). Specimens in collections: $\mathrm{CMNH}$, USNM. Note: $P$. boylii is not distributed in Chiapas according to Ceballos (2014).

Strepsylla taluna Traub and Johnson, 1952

CIUDAD DE MÉXICO: El Zarco: Peromyscus hylocetes. La Venta: P. maniculatus, Peromyscus sp. Parres: Neotomodon alstoni, Neotomodon sp. (Ayala-Barajas et al. 1988; Acosta 2011). Specimens in collections: CMNH, MZFC. $2 \mathrm{~km}$ SW of Parres: Neotomodon sp. (Ayala-Barajas et al. 1988). Specimens in collections: MZFC. Note: Neotomodon sp. likely refers to Neotomodon alstoni, as this is the only species in the genus ( $N$. orizabae and N. perotensis were synonymized with N. alstoni). ESTADO DE MÉXICO: Popocatépetl: Neotomodon alstoni, Peromyscus melanotis, Reithrodontomys chrysopsis (Barrera 1968). $5 \mathrm{mi} \mathrm{W}$ of Río Frío: $N$. alstoni. Laguna de Zempoala, $\mathrm{N}$ of Ojotongo: Neotomodon sp. (Ayala-Barajas et al. 1988). Specimens in collections: MZFC. 8 km W of Río Frío: N. alstoni. Lagunas de Zempoala near Ojotongo: Neotomodon sp. (Acosta 2011). Specimens in collections: BMNH, MZFC. Note: Neotomodon sp. likely refers to Neotomodon alstoni, as this is the only species in the genus ( $N$. orizabae and $N$. perotensis were synonymized with N. alstoni). MORELOS: 2 mi N of Tres Cumbres Marías; 3 mi N of Tres Marías: Neotomodon alstoni, Reithrodontomys megalotis (Traub and Johnson 1952c). Specimens in collections: AMNH. 11 km Tres Cumbres-Zempoala Highway: Peromyscus hylocetes (Barrera 1954a). $1 \mathrm{~km}$ NE of Lagunas de Zempoala: P. maniculatus (Ayala-Barajas et al. 1988; Acosta 2011). Specimens in collections: MZFC. Lagunas de Zampoala, near Ojo de Agua: Neotomodon sp. (Acosta 2011). Specimens in collections: USNM. Note: Neotomodon sp. likely refers to Neotomodon alstoni, as this is the only species in the genus ( $N$. orizabae and $N$. perotensis were synonymized with N. alstoni). Tres Marías: N. alsonti (Hopkins and Rothschild 1962). Specimens in collections: BMNH. QUERÉTARO: El Derramadero: Peromyscus difficilis, P. pectoralis (Acosta 2003). Specimens in collections: CMNH. Tolimán, El Derramadero: P. pectoralis (Acosta et al. 2008). Sierra Madre Oriental: Peromyscus difficilis (Gutiérrez-Velázquez and Acosta 2004). Specimens in collections: MZFC. TLAXCALA: La Malinche: Neotomodon alstoni, Peromyscus difficilis, Reithrodontomys fulvescens (Aguilar-Montiel et al. 2018). La Malinche: Peromyscus sp. (Acosta and Fernández 2006). Ixtenco, La Malinche (Caseta \#5): Peromyscus sp. (Acosta et al. 2008). Altamira, La Malinche (Caseta \#5): Peromyscus sp. (Acosta 2011). Specimens in collections: MZFC.

\section{Strepsylla tezontli Acosta, 2010}

ESTADO DE MÉXICO: Iztaccíhuatl, Veriente oriental: Microtus mexicanus, Peromyscus melanotis. Popocatépetl, Cerro Tlamaca: Neotomodon alstoni, P. melanotis. Popoca- tépetl; Paso de Cortez: N. alstoni. Otlaltepec; Nexpayantla; 1 km NE of Mirador del Poeta; Paraje Providencial; Río Frío: Peromyscus sp. Paraje Zumpango: P. melanotis (Acosta 2011). Specimens in collections: MZFC. TLAXCALA: La Malinche: Neotomodon alstoni, Peromyscus difficilis, P. melanotis (Aguilar-Montiel et al. 2018). Specimens in collections: MZFC.

\section{Strepsylla vargasi Acosta, 2010}

ESTADO DE MÉXICO: Peromyscus sp., Sigmodon sp. (Acosta 2010). Specimens in collections: IBUNAM. NUEVO LEÓN: $7.4 \mathrm{~km} \mathrm{~S}, 0.2 \mathrm{~km}$ W of San Josecito: Peromyscus sp. $5.2 \mathrm{~km} \mathrm{~N}, 0.2 \mathrm{~km}$ W of San Josecito: Peromyscus sp. (Acosta 2010, 2011). NUEVO LEÓN: Peromyscus sp., Sigmodon sp. (Acosta 2011). Specimens in collections: IBUNAM. ZACATECAS: 4.3 km N, 5.4 km E of San Juan Capistrano: Peromyscus sp. (Acosta 2011). Specimens in collections: IBUNAM.

\section{Strepsylla villai Traub and Barrera, 1955}

CIUDAD DE MÉXICO: Pedregal de San Angel: Peromyscus gratus (recorded as Peromyscus truei gratus; Ayala-Barajas et al. 1988; Acosta 2011). Cuajimalpa de Morelos, Cabeza del Toro, Parque Nacional Desierto de los Leones: Reithrodontomys sp. (Acosta et al. 2008; Acosta 2011). 2 km SW of Parres: Neotomodon sp. Popocatépetl, Diego de Ordaz: P. maniculatus. Popocatépetl, Mirador del Poeta; Popocatépetl, Tlamacas: P. melanotis. Popocatépetl, Paraje Providencial: P. maniculatus, P. melanotis. Popocatépetl, Pie del Ventorrillo: Peromyscus sp. (Acosta 2011). Specimens in collections: MZFC. Note: Neotomodon sp. likely refers to Neotomodon alstoni, as this is the only species in the genus ( $N$. orizabae and $N$. perotensis were synonymized with $N$. alstoni). ESTADO DE MÉXICO: Río Frío; $8 \mathrm{~km}$ W of Río Frío: Neotomodon alstoni (Acosta 2011). Specimens in collections: MZFC. GUERRERO: Taxco de Alarcón, Parque Estatal El Huizteco: Peromyscus levipes (Acosta et al. 2008). Specimens in collections: MZFC. OAXACA: Ixtlán de Juárez, 8.75 km SE of Santa María Yavesía: Peromyscus difficilis (Acosta et al. 2008). Specimens in collections: MZFC. PUEBLA: $1 \mathrm{~km}$ SW of San Pedro Atlixco: Peromyscus difficilis, Peromyscus sp. (Ayala-Barajas et al. 1988). Specimens in collections: MZFC. Atzitzintla, Santa Cruz Cuyachapa, Ejido Maguey Cenizo: Peromyscus sp. (Acosta et al. 2008; Acosta 2011). Specimens in collections: MZFC. QUERÉTARO: Tolimán, El Derramadero: Peromyscus pectoralis (Acosta 2011). Specimens in collections: MZFC. TLAXCALA: $10 \mathrm{~km} \mathrm{E}$ of Calpulalpan: Peromyscus difficilis (Traub and Barrera 1955, Acosta 2011). Specimens in collections: USNM. $10 \mathrm{~km}$ NE of Calpulalpan: Neotomodon sp. Humantla, La Malinche (Caseta \#4): Neotomodon alstoni, Reithrodontomys chrysopsis. Sanctorum, on the rural road to Benito Juárez; Tlaxco: Peromyscus sp. (Acosta 2011). Tlaxco: Peromyscus sp. La Malinche: N. alstoni, P. difficilis, P. gratus, P. maniculatus, P. melanotis, R. chrysopsis (Ayala- 
Barajas et al. 1988; Acosta and Fernández 2006; AguilarMontiel et al. 2018). Ixtenco, La Malinche (Caseta \#5): N. alstoni. Huamantla, Las Malinche (Caseta \#4): Microtus mexicanus, P. melanotis, R. chrysopsis. Sanctorum de Larzaro Cardenas, on the rural road to Benito Juárez, La Joya: Peromyscus sp. (Acosta et al. 2008). Specimens in collections: MZFC. Note: Neotomodon sp. likely refers to Neotomodon alstoni, as this is the only species in the genus ( $N$. orizabae and $N$. perotensis were synonymized with N. alstoni). VERACRUZ: Perote, $3 \mathrm{~km}$ S of El Frijol Colorado: Peromyscus difficilis (Acosta and Fernández 2015). Cofre de Perote: Reithrodontomys sp. (Acosta 2011). Specimens in collections: MZFC.

\section{Strepsylla sp.}

ESTADO DE MÉXICO: Popocatépetl: Neotomodon alstoni, Peromyscus maniculatus, P. melanotis (Barrera 1968). Popocatépetl, Diego de Ordaz: P. maniculatus. Popocatépetl, Mirador del Poeta; Popocatépetl Otlaltepec; Popocatépetl, Pie del Ventorrillo; Popocatépetl, 1 km NE Mirador del Poeta: Peromyscus sp. Popocatépetl, Praraje Providencial: P. maniculatus, P. melanotis. Popocatépetl, Paraje Zumpango; Popocatépetl, Tlamacas: P. melanotis. $5 \mathrm{mi}$ W of Río Frío: Neotomodon alstoni. 2 km SW of Parres: Neotomodon sp. (Ayala-Barajas et al. 1988). Specimens in collections: MZFC. Note: Neotomodon sp. likely refers to Neotomodon alstoni, as this is the only species in the genus ( $N$. orizabae and $N$. perotensis were synonymized with N. alstoni). GUERRERO: Omiltemi: Peromyscus sp. (Barrera 1958). Chilpancingo de los Bravo, Omiltemi: Peromyscus megalops (Acosta et al. 2008). Specimens in collections: MZFC. NUEVO LEÓN: Cerro Potosí: Peromyscus difficilis, P. melanotis, Peromyscus sp., Microtus mexicanus (Tipton and Mendez 1968). Unknown if specimens are in collections. Note: Tipton and Mendez (1968) reported this flea species as Strepsylla species and stated that it was to be described by Traub and Barrera. OAXACA: Santiago Comaltepec, Tuxtepec-Oaxaca Highway, km 87, El Suspiro: Peromyscus melanocarpus (Acosta et al. 2008). Specimens in collections: MZFC. TLAXCALA: La Malinche: Microtus mexicanus, Neotomodon alstoni, Peromyscus difficilis, P. gratus, P. maniculatus, P. melanotis, Heteromys irroratus (Aguilar-Montiel et al. 2018). 10 km NE of Calpulalpan: Neotomodon sp. (Ayala-Barajas et al. 1988). Specimens in collections: MZFC. Note: Neotomodon sp. likely refers to Neotomodon alstoni, as this is the only species in the genus ( $N$. orizabae and $N$. perotensis were synonymized with N. alstoni). VERACRUZ: Cofre de Perote: Reithrodontomys sp. (Ayala-Barajas et al. 1988). Specimens in collections: MZFC. SIERRA MADRE ORIENTAL: Multiple localities in Hidalgo and Querétaro: Peromyscus levipes, Peromyscus sp., Reithrodontomys sumichrasti (Gutiérrez-Velázquez and Acosta 2004). Specimens in collections: MZFC.

Wenzella obscura Traub, 1953

CHIAPAS: Tonala, El Triunfo: Heteromys desmarestianus (Acosta et al. 2008). Specimens in collecions: MZFC.
Rhadinopsyllinae Wagner, 1930

Rhadinopsylla fraterna (Baker, 1895)

ESTADO DE MÉXICO: Popocatépetl: Neotoma mexicana, Peromyscus maniculatus (Barrera 1968). Slope of Volcán Popocatépetl: P. melanotis (Barrera 1953). Popocatépetl, 300 m SW of Tlamacas: Neotoma sp. (Ayala-Barajas et al. 1988). Specimens in collections: MZFC. NUEVO LEÓN: Cerro Potosí: Peromyscus melanotis (Tipton and Mendez 1968). Unknown if specimens are in collections.

\section{Rhadinopsylla mexicana (Barrera, 1952)}

CIUDAD DE MÉXICO: Parque Nacional Insurgente Miguel Hidalgo y Costilla: Microtus mexicanus (Méndez-L. 1974). Unknown if specimens are in collections. ESTADO DE MÉXICO: Slopes of Volcán Popocatépetl: Peromyscus melanotis (Barrera 1952a; Tipton and Mendez 1968). Popocatépetl: Microtus mexicanus (Barrera 1952a; 1968). Iztaccíhuatl, Vert. Occid.: Neotomodon alstoni. Iztaccíhuatl, Vert. Occid., 1 km E of Trancas: M. mexicanus (Ayala-Barajas et al. 1988). Specimens in collections: MZFC. NUEVO LEÓN: Cerro Potosí: Mictrotus mexicanus, N. leucodon (recorded as N. albigula), Peromyscus difficilis, P. melanotis, Peromyscus sp. (Tipton and Mendez 1968). El Potosí, 18 km N of Galeana: M. mexicanus, P. maniculatus (Ayala-Barajas et al. 1988). Sierra Madre Oriental: P. maniculatus (Gutiérrez-Velázquez and Acosta 2004). Specimens in collections: MZFC.

\section{Rhadinopsylla sp.}

ESTADO DE MÉXICO: Lagunas de Zempoala, La Piedra; Nevado de Toluca, $16 \mathrm{mi}$ SW of Toluca: Microtus sp. Monte Río Frío: Neotoma mexicana (Ayala-Barajas et al. 1988). Specimens in collections: MZFC. NUEVO LEÓN: Cerro Potosí: Peromyscus maniculatus. El Potosí, 18 km N of Galeana: Microtus mexicanus, P. maniculatus (Ayala-Barajas et al. 1988). Specimens in collections: MZFC.

\section{Stenoponiinae Cunha, 1914}

Stenoponia americana (Baker, 1899)

HIDALGO: Tenango de Doria, $21 \mathrm{~km}$ NE of Metepec (by road): Megadontomys nelsoni (Salceda-Sánchez and Hastriter 2006). Specimens in collections: CAIM, InDRE. Note: Megadontomys sp. are not distributed in Hidalgo according to Ceballos (2014). NUEVO LEÓN: Sierra San Antonio Peña Nevada: Microtus mexicanus, Peromyscus maniculatus (Tijerina-Medina et al. 2006). No specimens in collections. PUEBLA: Cerro Chingnautla, 3 km W (by road) of Chignautla: Peromyscus levipes (Salceda-Sánchez and Hastriter 2006). Specimens in collections: CAIM, InDRE.

\section{Stenoponia ponera Traub and Johnson, 1952}

CIUDAD DE MÉXICO: La Venta: Peromyscus hylocetes, P. maniculatus (Barrera 1953). Specimens in collections: MZFC. DURANGO: Laguna del Progresso: Peromyscus sp. 
(Traub and Johnson 1952c). Specimens in collections: AMNH, USNM. ESTADO DE MÉXICO: San Cayetano: Microtus mexicanus, Peromyscus sp. (Machado-A. 1960; Ayala-Barajas et al. 1988). Specimens in collections: MZFC. La Venta: Peromyscus hylocetes, P. maniculatus (Barrera 1953). El Zarco: M. mexicanus sp. nest. (Ayala-Barajas et al. 1988). Specimens in collections: MZFC. NUEVO LEÓN: Cerro Potosí: Peromyscus difficilis, P. melanotis, Peromyscus sp., Microtus mexicanus (Tipton and Mendez 1968). Unknown if specimens are in collections. QUERÉTARO: $1 \mathrm{~km}$ SE of Chavarría, Cadereyta de Montes: Peromyscus difficilis. Pinal de Amoles, $1 \mathrm{~km} \mathrm{~S}$ of Pinal de Amoles: Neotoma mexicana, P. difficilis, P. levipes, Peromyscus sp. $1 \mathrm{~km}$ SW of Pinal de Amoles: P. difficilis, $P$. levipes. Pinal de Amoles, $3.5 \mathrm{~km} S$ of Pinal de Amoles; Pinal de Amoles, $5.6 \mathrm{~km} S$ of Tejamanil: $P$. levipes (recorded as $P$. boylii levipes; Acosta 2003, Acosta et al. 2008). Sierra Madre Oriental: P. difficilis, P. levipes, Microtus mexicanus, Neotoma mexicana (Gutiérrez-Velázquez and Acosta 2004). Specimens in collections: MZFC.

\section{Stenoponia sp.}

QUERÉTARO: $1 \mathrm{~km}$ S of Pinal de Amoles: Peromyscus difficilis (Acosta 2003). Specimens in collections: MZFC.

Hystrichopsyllidae Tiraboschi, 1904

Hystrichopsyllinae Tiraboschi, 1904

Atyphloceras echis Jordan and Rothschild, 1915

SONORA: La Mesa: Peromyscus maniculatus (Zapata-Valdés et al. 2018). No specimens in collections. QUERÉTARO: 1 km S of Pinal de Amoles: Microtus mexicanus (Acosta 2003). Specimens in collections: MZFC.

\section{Atyphloceras multidentatus alvarezi Barrera, 1963}

GUERRERO: Agua Fría, 32 km SW of Yextla: Peromyscus megalops (Barrera 1963). Camotla, Mpío. de Chichihualco: Osgoodomys banderanus (recorded as Peromyscus banderanus; Barrera 1963; Ayala-Barajas et al. 1988). Specimens in collections: MZFC.

Atyphloceras tancitari Traub and Johnson, 1952

CIUDAD DE MÉXICO: La Venta: Peromyscus maniculatus (Barrera 1953; Hopkins and Rothschild 1962; Ayala-Barajas et al. 1988). Specimens in collections: BMNH, MZFC. Parque Nacional Insurgente Miguel Hidalgo y Costilla: Microtus mexicanus (Méndez-L 1974). Unknown if specimens are in collections. La Venta: Peromyscus maniculatus (Hopkins and Rothschild 1962). Specimens in collections: BMNH. ESTADO DE MÉXICO: Popocatépetl: Neotomodon alstoni, Peromyscus difficilis, P. melanotis, Reithrodontomys sp. (Barrera 1968; AyalaBarajas et al. 1988). Nevado de Toluca, Ojo de Agua, $16 \mathrm{mi}$ al SSO de Toluca: Peromyscus sp. Lagunas de Zempoala, Ojotongo: Microtus sp., Reithrodontomys sp. nest. Iztaccíhuatl, Vert. Occid: P. melanotis. Popocatépetl, Paraje Providencia:
N. alstoni, P. maniculatus. Popocatépetl, 5 km E of San Pedro Nexapa; Popocatépetl, San Pedro Nexapa: P. maniculatus (Ayala-Barajas et al. 1988). Specimens in collections: MZFC. GUERRERO: San Miguel Totolapan, Puerto del Gallo: Megadontomys thomasi. San Miguel Totolapan, Estación Toro Muerto: Peromyscus sp. (Acosta et al. 2008). Specimens in collections: MZFC. HIDALGO: Tlanchinol: Reithrodontomys chrysopsis (Salceda-Sánchez and Hastriter 2006). Specimens in collections: CAIM, InDRE. Note: R. chrysopsis is not distributed in this part of Hidalgo according to Ceballos (2014). MICHOACÁN: Tancítaro: Reithrodontomys chrysopsis, Microtus mexicanus, Peromyscus hylocetes, P. melanotis (Traub and Johnson 1952b; Barrera 1953; Hopkins and Rothschild 1962). Specimens in collections: BMNH, FMNH. MORELOS: Derrame del Chichinautzin: Peromyscus difficilis (Pérez-Ortiz 1976; Ayala-Barajas et al. 1988). Atzompa, Huitzilac: P. hylocetes (Ayala-Barajas et al. 1988). pecimens in collections: MZFC. OAXACA: Ixtlán de Juárez, 6.5 km E-SE of Santa María Yavesía: Oryzomys sp., Peromyscus difficilis, P. melanocarpus. Ixtlán de Juárez, 6.5 km SE of Santa María Yavesía: P. mexicanus. Ixtlán de Juárez, $8.75 \mathrm{~km}$ SE of Santa María Yavesía: P. difficilis (Acosta et al. 2008). Specimens in collections: MZFC. QUERÉTARO: Xilitla-Jalpan Highway: Peromyscus levipes (Acosta 2003). Specimens in collections: MZFC. TLAXCALA: La Malinche: Neotomodon alstoni, Peromyscus difficilis, P. melanotis (Aguilar-Montiel et al. 2018). Specimens in collections: MZFC.

Hystrichopyslla cryptotis Acosta and Morrone, 2005

HIDALGO: Tlanchinol: Peromyscus furvus (Salceda-Sánchez and Hastriter 2006). Specimens in collections: CAIM, InDRE. OAXACA: Ixtlán de Juárez, 6.5 km E-SE of Santa María Yavesía: Peromyscus aztecus. Ixtlán de Juárez, $4.5 \mathrm{~km}$ SE of Santa María Yavesía: P. mexicanus (Acosta et al. 2008). Specimens in collections: MZFC.

\section{Hystrichopyslla dippiei Rothschild, 1902}

NUEVO LEÓN: Cerro Potosí, 18 km N of Galeana: Peromyscus maniculatus (Ayala-Barajas et al. 1988). Sierra Madre Oriental: P. maniculatus (Gutiérrez-Velázquez and Acosta 2004). Specimens in collections: MZFC.

Hystrichopyslla llorentei Ayala and Morales, 1990

GUERRERO: Atoyac de Álvarez, Puerto del Gallo-Paraíso Highway, km 14; General Heliodoro Castillo, El Iris: Peromyscus megalops (Acosta et al. 2008). Specimens in collections: MZFC. OAXACA: Ixtlán de Juárez, 8.75 km SE of Santa María Yavesía: Peromyscus difficilis (Acosta et al. 2008). Specimens in collections: MZFC.

\section{Hystrichopyslla occidentalis Holland, 1949}

OAXACA: Ixtlán de Juárez, 6.5 km E-SE of Santa María Yavesía: Microtus mexicanus, Peromyscus difficilis. Ixtlán de Juárez, 8.75 km SE of Santa María Yavesía: P. difficilis (Acosta et al. 2008). Specimens in collections: MZFC. 
Hystrichopyslla orophila Barrera, 1952

CIUDAD DE MÉXICO: Parque Nacional Insurgente Miguel Hidalgo y Costilla: Microtus mexicanus (Méndez-L. 1974). Unknown if specimens are in collections. Zarco: M. mexicanus (Ayala-Barajas et al. 1988). Specimens in collections: MZFC. ESTADO DE MÉXICO: Slope of Volcán Popocatépetl: Microtus mexicanus (Barrera 1952b; 1953). Popocatépetl: Microtus mexicanus, Peromyscus maniculatus, Reithrodontomys chrysopsis (Hopkins and Rothschild 1962; Barrera 1968). Nevado de Toluca, 4 mi S of Raíces: Peromyscus sp. (Ayala-Barajas et al. 1988). Specimens in collections: MZFC. MICHOACÁN: Tancítaro: Neotomodon alstoni (Traub and Johnson 1952c). Specimens in collections: FMNH. Note: See Morales and Llorente (1986) for additional information about this association. QUERÉTARO: $1 \mathrm{~km}$ $S$ of Pinal de Amoles: Peromyscus levipes (Acosta 2003). Sierra Madre Oriental: P. levipes (Gutiérrez-Velázquez and Acosta 2004). Specimens in collections: MZFC.

\section{Hystrichopyslla sp.}

GUERRERO: Omiltemi: Peromyscus megalops (Barrera 1958). Omiltemi: Peromyscus sp. 22 km SW of Yextla: Peromyscus megalops (Ayala-Barajas et al. 1988). Specimens in collections: MZFC. NUEVO LEÓN: Cerro Potosí: Neotoma leucodon (recorded as N. albigula), Peromyscus difficilis, $P$. melanotis (Tipton and Mendez 1968). Unknown if specimens are in collections. Note: The specimens from Tipton and Mendez (1968) were reported as Hystrichopsylla species, to be described by Traub and Barrera. OAXACA: $7 \mathrm{~km}$ S of Suchitepec: Peromyscus sp. (Ayala-Barajas et al. 1988). Specimens in collections: MZFC. QUERÉTARO: $1 \mathrm{~km}$ $S$ of Pinal de Amoles: Peromyscus difficilis, P. levipes (Acosta 2003). Specimens in collections: MZFC.

Ischnopsyllidae Wahlgren, 1907

Myodopsylla gentilis Jordan and Rothschild, 1921

OAXACA: Ixtlán de Juárez, 2.5 km SE of Santa María Yavesía: Peromyscus mexicanus (Acosta et al. 2008). Specimens in collections: MZFC.

Leptopsyllidae Rothschild, 1915

Leptopsyllinae Rothschild and Jordan, 1915

Peromyscopsylla draco Hopkins, 1951

CHIHUAHUA: Guachochic: Peromyscus maniculatus (Johnson and Traub 1954). Unknown if specimens are in collections. Guachochic a Batopilas, Sierra Tarahumara: Peromyscus maniculatus (Ayala-Barajas et al. 1988). Specimens in collections: MZFC.

Peromyscopsylla hesperomys adelpha (Rothschild, 1915)

DURANGO: Hidalgo, 4 km S-SE of la Zarca: Peromyscus maniculatus (Acosta et al. 2006; 2008). Specimens in collections: MZFC. ESTADO DE MÉXICO: Popocatépetl: Peromyscus difficilis, P. maniculatus, P. melanotis (Barrera
1968). Popocatépetl, 5.5 km E of San Pedro Nexapa: $P$. maniculatus. Popocatépetl, San Pedro Nexapa: P. difficilis (Ayala-Barajas et al. 1988). Specimens in collections: MZFC. GUERRERO: Tlacotepec, Cerro de Teotepec: Peromyscus boylii (Acosta et al. 2008). Specimens in collections: MZFC. Note: P. boylii is not distributed in Guerrero according to Ceballos (2014). MICHOACÁN: Peromyscus sp. (Johnson and Traub 1954). Unknown if specimens are in collections. Note: Tipton and Mendez (1968) also report that this flea species has been collected from Michoacán ex. Peromyscus sp. MORELOS: Laguna de Zempoala, 1 km NE de al Laguna: Peromyscus hylocetes, P. maniculatus (Barrera 1954a). Specimens in collections: BMNH, MZFC. Zempoala: P. maniculatus (Hopkins and Rothschild 1971). Specimens in collections: BMNH (BMNH 1958.328). NUEVO LEÓN: Cerro Potosí: Peromyscus melanotis (Tipton and Mendez 1968). Unknown if specimens are in collections. ZACATECAS: El Pinal: Neotoma mexicana (Ayala-Barajas et al. 1988). Specimens in collections: MZFC.

Pulicidae Billberg, 1820

Ctenocephalides felis (Bouché, 1835)

CIUDAD DE MÉXICO: Chapultepec: Microtus mexicanus (Barrera 1953). Specimens in collections: MZFC. YUCATÁN: Mpio. of Oxkutzcab: Peromyscus yucatanicus (Peniche-Lara et al. 2015). No specimens in collections.

\section{Echidnophaga gallinacea (Westwood, 1875)}

CHIHUAHUA: Janos Biosphere Reserve: Neotoma albigula, Onychomys arenicola, Peromyscus leucopus, Chaetodipus hispidus, Dipodomys merriami, D. spectabilis (Fernández-González et al. 2016). No specimens in collections. MICHOACÁN: Zamora: Heteromys sp. (AyalaBarajas et al. 1988). Specimens in collections: MZFC. PUEBLA: Multiple localities: Heteromys irroratus (Acosta and Fernández 2015). $1.5 \mathrm{~km}$ S Oriental, Mpio. de Oriental: H. irroratus (Falcón-Ordaz et al. 2012). Specimens in collections: MZFC. QUERÉTARO: $8 \mathrm{~km} \mathrm{~N}$ of Jalpan: Heteromys irroratus. Maguey Verde: Peromyscus difficilis (Acosta 2003). Amealco de Bonfil, Galindo-Amealco Highway km 11: Peromyscus levipes. Jalpan de Serra, 8 $\mathrm{km} \mathrm{N}$ of Jalpan: $H$. irroratus (Acosta et al. 2008). Specimens in collections: MZFC. SONORA: $60 \mathrm{~km}$ NW of Caborca (km 2450); Rancho Noche Buena, 30 km N-NW of Guaymas: Neotoma sp. (Ayala-Barajas et al. 1988). Specimens in collections: MZFC. VERACRUZ: near El Frijol Colorado, Mpio. of Perote: Neotoma nelsoni (Acosta and Fernández 2009). Specimens in collections: MZFC.

\section{Echidnophaga sp.}

SIERRA MADRE ORIENTAL: Multiple locations in Nuevo León and Veracruz: Peromyscus difficilis (Gutiérrez-Velázquez and Acosta 2004). Specimens in collections: MZFC. 
Euhoplopsyllus glacialis affinis (Baker, 1904)

NUEVO LEÓN: Sierra San Antonio Peña Nevada: Neotoma goldmani, N. mexicana, Peromyscus boylii, P. maniculatus (Tijerina-Medina et al. 2006). No specimens in collections. Note: P. boylii is not distributed in Nuevo León according to Ceballos (2014). QUERÉTARO: Peña Bernal: Peromyscus difficilis (Acosta 2003). Specimens in collections: MZFC.

\section{Pulex irritans Linnaeus, 1758}

QUERÉTARO: $8 \mathrm{~km} \mathrm{~N}$ of Jalpan: Heteromys irroratus (Acosta 2003; Acosta et al. 2008). Specimens in collections: MZFC.

\section{Pulex simulans Baker, 1895}

NUEVO LEÓN: Cerro Potosí: Microtus mexicanus (Tipton and Mendez 1968). Unknown if specimens are in collections. SONORA: 60 km NW of Caborca (km 2450): Peromyscus sp. (Ayala-Barajas et al. 1988). Specimens in collections: MZFC. YUCATÁN: Heteromys gaumeri (Eckerlin 2005). Specimens in collections: CMNH B57315.

\section{Pulex sp.}

CIUDAD DE MÉXICO: San Ángel: Neotoma sp. (AyalaBarajas et al. 1988). Specimens in collections: MZFC.

\section{Tungidae Taschenberg, 1880}

Tunga monositus Barnes and Radovsky, 1969

BAJA CALIFORNIA: San Martín Island: Peromyscus maniculatus. Mainland: P. fraterculus, P. maniculatus (Camargo et al. 2017). No specimens in collections. Bahía de San Quintín: Neotoma bryanti, N. martinensis, Peromyscus fraterculus, P. maniculatus (Barnes and Radowsky 1969). Specimens in collections: USNM. Note: N. martinensis is considered extinct. Note: Other hosts include Peromyscus crinitus and Neotoma sp. (Barnes and Radowsky 1969; Hastriter 1997; Linardi and Moreira de Avelar 2014). P. maniculatus is not known to occur on San Martin Island (Ceballos 2014). P. eremicus was recognized as the original host. However, $P$. eremicus from the northern part of the Baja California peninsula is now recognized as $P$. fraterculus (Álvarez-Castañeda et al. 2010). N. lepida was recognized as the original host. However, all Neotoma from the Baja California peninsula are now recognized as N. bryanti (Patton et al. 2007).

Rhopalopysllidae Oudemans, 1909

Rhopalopsyllinae Oudemans, 1909

Polygenis (Polygenis) adocetus Traub, 1950

QUERÉTARO: Peña Bernal, Ezequiel Montes: Peromyscus sp. $5 \mathrm{~km}$ SE of Tequisquiapan, Tequisquiapan: Heteromys irroratus (Acosta 2003; Acosta et al. 2008). Specimens in collections: MZFC.

\section{Polygenis (Polygenis) gwyni (C. Fox, 1914)}

CAMPECHE: $128 \mathrm{~km}$ E of Escarcega: Sigmodon hispidus (Eckerlin 2005). Specimens in collections: CMNH. Note: S. hispidus is not distributed in Campeche according to Ceballos (2014). A possible alternative host includes $S$. toltecus (Ceballos 2014). CHIHUAHUA: To the N of Rancho Santa Barbara: "Cotton rat" (Ayala-Barajas et al. 1988). Specimens in collections: MZFC. MICHOACÁN: Mt. St. Miguel: "Rat" (Smit 1987). Specimens in collections: BMNH. Note: Host most likely to be a cricetid rodent. QUERÉTARO: San Miguel Palma, Peñamiller; $9 \mathrm{~km}$ SE of Tequisquiapan, Tequisquiapan: Heteromys irroratus. $5 \mathrm{~km}$ SE of Tequisquiapan, Tequisquiapan: $\mathrm{H}$. irroratus, Sigmodon hispidus (Acosta 2003; Acosta et al. 2008). Specimens in collections: MZFC. Note: S. hispidus is not distributed in Querétaro according to Ceballos (2014). A possible alternative host includes S. leucotis (Ceballos 2014). QUINTANA ROO: Sigmodon hispidus. Isla Cozumel, $3.5 \mathrm{~km} \mathrm{~N}$ of San Miguel: Reithrodontomys sp. (Eckerlin 2005). Specimens in collections: $\mathrm{CMNH}$. Note: S. hispidus is not distributed in Quintana Roo according to Ceballos (2014). A possible alternative host includes S. leucotis (Ceballos 2014). SAN LUIS POTOSÍ: San Bartolo Mpio De Río Verde: Sigmodon sp. (Ayala-Barajas et al. 1988). Specimens in collections: MZFC.

Polygenis (Polygenis) martinezbaezi Vargas, 1951

GUANAJUATO: Cortazar: Sigmodon hispidus (Ayala-Barajas et al. 1988). Specimens in collections: MZFC. Note: S. hispidus is not distributed in Guanajuato according to Ceballos (2014). Possible alternative hosts include S. fulviventer and S. leucotis (Ceballos 2014). GUERRERO: Atoyac de Álvarez, Puerto del Gallo-Paraíso Highway, Km 14: Peromyscus sp. Atoyac de Álvarez, El Faisanal: Oryzomys palustris, Oryzomys sp., Heteromys pictus. Chilpancingo de los Bravo, 4 km N of Omiltemi: Peromyscus boylii. Tetipac, Huizteco-Tetipac Highway, km 10, Los Llanos: P. aztecus (Acosta et al. 2008). Specimens in collections: MZFC. Note: $O$. palustris is not distributed in Guerrero and $P$. boylii is not distributed in Guerrero according to Ceballos (2014). Note: Oryzomys sp. was recorded in the original literature but may represent Handleyomys sp. JALISCO: 7 km S of Acatlán: Heteromys sp. (AyalaBarajas et al. 1988). Specimens in collections: MZFC. La Barca, Hacienda Briseñas: Sigmodon sp. (Smit 1987). Specimens in collections: BMNH. MICHOACÁN: La Barca, Jalisco, and Briseñas: Sigmodon sp. (Vargas 1951d). Specimens in collections: ISET. $10 \mathrm{~km}$ E of Zamora: Heteromys irroratus (Ayala-Barajas et al. 1988). Specimens in collections: MZFC. OAXACA: Miahuatlán de Porfirio Díaz, 2.3 km de Finca Brasil: Peromyscus sp. (Acosta et al. 2008). Specimens in collections: MZFC. QUERÉTARO: Ezequiel Montes, $5 \mathrm{~km}$ W of Peña Bernal: Sigmodon hispidus. Peñamiller, San Miguel Palma: Heteromys irroratus (Acosta et al. 2008). Specimens in collections: MZFC. Note: S. hispidus is not distributed in Querétaro according to Ceballos (2014). Possible host includes $S$. leucotis (Ceballos 2014). TLAXCALA: El Carmen Tequexqui- 
tla, El Piñonal: Heteromys irroratus. Calpulalpan, San Felipe Hidalgo, Piedra Canteada: Neotoma mexicana. Huamantla, La Malinche (Caseta \#4): Reithrodontomys megalotis (Acosta et al. 2008). Specimens in collections: MZFC.

\section{Polygenis (Polygenis) odiosus Smit, 1958}

CAMPECHE: $7.5 \mathrm{~km}$ W of Escárcega: Ototylomys phyllotis (Eckerlin 2005). Specimens in collections: CMNH. QUINTANA ROO: Isla Cozumel, 3.5 km N of San Miguel: Oryzomys couesi. Pueblo Nuevo X-Cán: Peromyscus yucatanicus (Eckerlin 2005). Specimens in collections: CMNH. YUCATÁN: 4 km N-NE of Felipe Carrillo Puerto; Uxmal; Mérida: Peromyscus yucatanicus. $3 \mathrm{~km} \mathrm{~N}$ of Piste; $66 \mathrm{~km} \mathrm{NE}$ of Mérida; $5 \mathrm{~km} \mathrm{~W}$ of Merida: Ototylomys phyllotis (Eckerlin 2005). Specimens in collections: $\mathrm{BMNH}, \mathrm{CMNH}$, RPE. Mpio. of Oxkutzcab: Ototylomys phyllotis (Peniche-Lara 2015). No specimens in collections. $12 \mathrm{~km} \mathrm{~N}$ of Mérida: Peromyscus yucatanicus (Smit 1987). Specimens in collections: BMNH.

\section{Polygenis (Polygenis) rozeboomi Vargas, 1952}

COLIMA: Potrero Grande: Sigmodon sp. (Vargas 1952). Specimens in collections: BMNH, ISET.

\section{Polygenis (Polygenis) vazquezi Vargas, 1951}

CHIAPAS: Pan-American Highway over Río San Gregorio, $20 \mathrm{mi}$ from Guatemalan border: Neotoma ferruginea, Peromyscus guatemalensis (recorded as $P$. mexicanus guatemalensis; Ayala-Barajas et al. 1988). Specimens in collections: MZFC. Note: Flea specimens from Chiapas were originally reported as Polygenis vulcanius Smit, 1958, now a synonym of $P$. vazquezi. CIUDAD DE MÉXICO: kms 14 and 45 Free México-Cuernavaca Highway: Neotomodon alstoni (Vargas 1951c). Specimens in collections: IBUNAM. DURANGO: Hidalgo $4 \mathrm{~km} \mathrm{S-SE} \mathrm{of} \mathrm{la} \mathrm{Zarca:} \mathrm{Perognathus} \mathrm{fla-}$ vus (Acosta et al. 2006; Acosta et al. 2008). Specimens in collections: MZFC. GUERRERO: Atoyac de Álvarez, Nueva Dehli: Handleyomys guerrerensis (recorded as Oryzomys chapmani guerrerensis; Acosta et al. 2008). Specimens in collections: MZFC. HIDALGO: Huehuetla, Huehuetla: Peromyscus mexicanus, Sigmodon hispidus (Acosta et al. 2008). Specimens in collections: MZFC. Note: S. hispidus is not distributed in Hidalgo according to Ceballos (2014). A possible alternative host includes S. leucotis (Ceballos 2014). MORELOS: Comitán de Domínguez: Sigmodon hispidus. San Pedro Tapanatepec: Heteromys pictus (Smit 1987). Specimens in collections: BMNH. Note: S. hispidus is not distributed in Morelos according to Ceballos (2014). A possible alternative host includes S. leucotis (Ceballos 2014). OAXACA: Veracruz: Peromyscus boylii. Tepanatepec: Heteromys pictus (Hubbard 1958). Specimens in collections: BMNH. Note: $P$. boylii is not distributed in Oaxaca according to Ceballos (2014). PUEBLA: San Juan Tetla, Mpio. de Chautzingo: Neotomodon alstoni (Ramírez 1982). Unknown if specimens are in collections. $1.5 \mathrm{~km}$ S Oriental, Mpio. de Oriental: Het- eromys irroratus (Falcón-Ordaz et al. 2012). Specimens in collections: MZFC. QUERÉTARO: Peñamiller, Peñamiller: Sigmodon hispidus (Acosta 2003; Acosta et al. 2008). 5 km SW of Tequisquiapan: Heteromys irroratus (Acosta 2003). Specimens in collections: MZFC. Note: S. hispidus is not distributed in Querétaro according to Ceballos (2014). A possible alternative host includes S. leucotis (Ceballos 2014). TLAXCALA: 2.5 km NW El Carmen Tequexquitla, Mpio. de El Carmen Tequexquitla: Heteromys irroratus (Falcón-Ordaz et al. 2012). Specimens in collections: MZFC. ORIENTAL BASIN: Multiple localities in Puebla, Tlaxcala, and Veracruz: Peromyscus difficilis, Heteromys irroratus (Acosta and Fernández 2015). Specimens in collections: MZFC. UNKNOWN LOCALITY: Peromyscus boylii (Smit 1987). Specimens in collections: $\mathrm{BMNH}$.

\section{Polygenis sp.}

CAMPECHE: 128 km E of Escarcega: Sigmodon toltecus (listed as S. hispidus microdon; Ayala-Barajas et al. 1988; Eckerlin 2005). Specimens in collections: CMNH, MZFC. CHIAPAS: Ocosingo, Zona Arqueológica Monumento Natural, Ocosingo: Ototylomys phyllotis, Heteromys desmarestianus (Acosta et al. 2008). Specimens in collections: MZFC. JALISCO: 20 km de Guadalajara: Baiomys sp., Heteromys sp. (Ayala-Barajas et al. 1988). Specimens in collections: MZFC. OAXACA: $13 \mathrm{~km}$ S of San Juan Lachao: Oryzomys sp. (AyalaBarajas et al. 1988). Specimens in collections: MZFC. Note: Oryzomys sp. was recorded in the original literature but may represent Handleyomys sp. PUEBLA: $6 \mathrm{~km}$ E of Tutumihuacan: Sigmodon sp. (Ayala-Barajas et al. 1988). Specimens in collections: MZFC. QUERÉTARO: $5 \mathrm{~km}$ W of Peña Bernal: Sigmodon hispidus (Acosta 2003). Specimens in collections: MZFC. Note: S. hispidus is not distributed in Querétaro according to Ceballos (2014). A possible alternative host includes S. leucotis (Ceballos 2014). QUINTANA ROO: Pueblo Nuevo Xcan: Peromyscus yucatanicus, Peromyscus sp. (AyalaBarajas et al. 1988; Eckerlin 2005). Isla Cozumel, 3.5 km N of San Miguel: Oryzomys couesi (Eckerlin 2005). Specimens in collections: CMNH, MZFC. SAN LUIS POTOSÍ: $5 \mathrm{~km}$ SW of Nuñez: Sigmodon sp. (Ayala-Barajas et al. 1988). Specimens in collections: MZFC. YUCATÁN: 3 km N of Pisté: Oryzomys sp., Peromyscus yucatanicus (Eckerlin 2005). Specimens in collections: CMNH. Península de Yucatán: Oryzomys sp. 2 km N of Pisté: Peromyscus yucatanicus (Ayala-Barajas et al. 1988). Specimens in collections: MZFC. Note: Oryzomys sp. was recorded in the original literature but may represent Handleyomys sp.

\section{Acknowledgments}

We thank J. A. Fernández for providing this opportunity to publish this checklist. Comments from several anonymous reviewers helped to improve the quality of this checklist. This is publications 1613 of the Biodiversity Research and Teaching Collections at Texas A\&M University. 


\section{Literature cited}

Acosta, R. 2003. New records of rodent fleas from Queretaro, Mexico (Siphonaptera). Zootaxa 369:1-15.

Acosta, R. 2010. Five new Mexican species of the flea genus Strepsylla Traub, 1950 (Siphonaptera: Ctenophthalmidae: Neopsyllinae: Phalacropsyllini) with a phylogenetic analysis. Journal of Parsitology 96:285-298.

Acosta, R. 2011. Distributional data and taxonomic notes on the flea Strepsylla (Siphonaptera: Ctenophthalmidae: Neopsyllinae: Phalacropsyllini). Revista Mexicana de Biodiversidad 82:1154-1162.

Acosta, R. 2014. Biodiversity of Siphonaptera in Mexico. Revista Mexicana de Biodiversidad 85:S345-S352.

Acosta, R., AND J. J. Morrone. 2003. Clave ilustrada para la identificación de los taxones supraespecíficos de Siphonaptera de México. Acta Zoologica Mexicana 89:39-53.

Acosta, R., and J. A. Fernández. 2006. Pulgas (Insecta: Siphonaptera) Fauna de pulgas asociada a mamíferos. Pp. 157-174 in Biodiversidad del Parque Nacional Malinche Tlaxcala, México (Fernández, J. A. and J. C. López-Domínguez, eds.). Coordinación General de Ecología, Gobierno del Estado de Tlaxcala, Tlaxcala, México.

Acosta, R., and J. A. Fernández. 2009. A new species of Anomiopsyllus Baker, 1904 (Insecta: Siphonaptera), and noteworthy records of fleas from Nelson's woodrat, Neotoma nelsoni (Rodentia: Cricetidae), in the Oriental Basin, Mexico. Journal of Parasitology 95:532-535.

Acosta, R., and J. A. Fernández. 2015. Flea diversity and prevalence on arid-adapted rodents in the Oriental Basin, Mexico. Revista Mexicana de Biodiversidad 86:981-988.

Acosta, R., AND M. W. Hastriter. 2017. A review of the flea genus Phalacropsylla Rothschild, 1915 (Siphonaptera, Ctenophthalmidae, Neopsyllinae, Phalacropsyllini) with new host and distributional records. Zookeys 675:27-43.

Acosta, R., J. A. Fernández, and J. Falcón-Ordaz. 2006. New records of mammal fleas (Siphonaptera) in northern and central Mexico. Entomological News 117:69-72.

Acosta, R., B. Salceda-Sánchez, and H. E. Ponce-Ulloa. 2009. Two new species of fleas of the genus Kohlsia Traub, 1950 (Siphonaptera: Ceratophyllidae) from Mexico. Zootaxa 2224:60-68.

Acosta, R., J. A. Fernández, J. Llorente Bousquets, and M. Carmen Jiménez. 2008. Catálogo de Pulgas (Insecta: Siphonaptera) En El Museo de Zoología, Facultad de Ciencias UNAM. Volumen 2. Universidad Nacional Autónoma de México. Ciudad de México, México.

Aguilar-Montiel, F., A. Estrada Torres, R. Acosta, M. Rubio-Godoy, AND J. VÁzquez. 2018. The host species influence on infection parameters of terrestrial micromammal fleas (Siphonaptera) in a temperate forest of Mexico. Parasitology 29:1-8.

Ayala-Barajas, R., J. C. Morales, N. Wilson, J. E. Llorente and H. E. PoncE. 1988. Catálogo de las pulgas (Insecta: Siphonaptera) en el Museo de Zoología, Facultad de Ciencias, Universidad Nacional Autónoma de México. 1: Colección Alfredo Barrera. Serie de Catálogos del Museo de Zoología “Alfonso L. Herrera" 1:1-102.

Álvarez-Castañeda, S. T., P. Cortés-Calva, F. X. González-Cózatl, D. Rojas and I. Leyva. 2010. Comparison of distribution and habitat characteristics between an endemic and a wide ranging cryptic species of Peromyscus on the Baja California Peninsula. Western North American Naturalist 70:323-333.

Álvarez-Castañeda, S. T., and E. Rios. 2011. Revision of Chaetodipus arenarius (Rodentia: Heteromyidae). The Zoological Journal of the Linnean Society 161:213-228.

Barnes, A. M. 1965. Three new species of the genus Anomiopsyllus. The Pan-Pacific Entomologist 41:272-280.

Barnes, A. M., and F. J. Radovsky. 1969. A new Tunga (Siphonaptera) from the Nearctic region with description of all stages. Journal of Medical Entomology 6:19-36.

Barnes, A. M., V. J. Tipton, And J. A. Wilde. 1977. The subfamily Anomiopysllinae (Hystrichopsyllidae: Siphonaptera). I. A revision of the genus Anomiopysllus Baker. Great Basin Naturalist 37:138-206.

BarRera, A. 1952a. Notas sobre sifonápteros. III. Descripción de Ractofrontia mexicana nov. sp. (Siph. Hystrichops.). Ciencia, México 9:293-294.

BarRera, A. 1952b. Notas sobre sifonápteros. IV. Descripción de Hystrichopsylla orophila nov. sp. (Siph., Hystrichops.). Ciencia, México 12:39-42.

Barrera, A. 1953. Sinopsis de los sifonápteros de la Cuenca de México. (Ins. Siph.). Anales de la Escuela Nacional de Ciencias Biológicas 7:155-245.

Barrera, A. 1954a. Notas sobre sifonápteros. VII. Lista de especies colectadas en el Municipio de Huitzilac, Morelos, y descripción de Peromyscopsylla zempoalensis nov. sp. (Siph. Leptops). Ciencia 14:87-90.

Barrera, A. 1954b. Notas sobre sifonápteros. VIII. Nuevas localidades de especies concidas y nuevas para Mexico y disgnosis de Pleochatis apollinaris aztecus subsp. nov. Ciencia 14:137-139.

Barrera, A. 1955a. Notas sobre sifonápteros. IX. Algunas especies mexicanas; consideraciones sobre su distribución geográfica. Revista de la Sociedad Mexicana Entomología 1:85-98.

BarRera, A. 1955b. Un nuevo sifonáptera mexicano: Pleochaetis ponsi nov. sp. (Cerat.). Acta Zoológica Mexicana 1: 1-7.

BarRera, A. 1956. Notas sobre sifonápteros. IX. Descripción de Kohlsia pelaezi nov. sp. (Siph, Cerat.). Ciencia, México 16:13-16.

BarRera, A. 1958. Insectos parásitos de mamíferos salvajes de Omiltemi, Gro, y descripción de un Nuevo sifonáptero: Pleochaetis soberoni nov. sp. Anales de la Escuela Nacional de Ciencias Biológicas 9:89-96.

Barrera, A. 1963. Diagnosis de Atyphloceras multidentatus salvarezi subsp. nov. (Siphonaptera: Hystrichopsyllidae). Anales de la Escuela Nacional de Ciencias Biológicas 12:97100.

Barrera, A. 1968. Distribución cliserial de los Siphonaptera del Volcán Popocatépetl, su interpretación biogeográfica. Anales del Instituto de Biología, Universidad Nacional Autónoma de México 39:35-100.

Barrera, A., AND C. Machado-A. 1960. Un nuevo ectoparásito de Microtus m. mexicanus Saussure: Ctenophthalmus caballeroi sp. nov. y claves para las especies americanas hasta ahora conocidas (Insecta: Siphonaptera). Pp. 549-553 in Libro homenaje al Dr. Caballero y Caballero. Instituto Politécnico Nacional. Ciudad de México, México.

Barrera, A., and R. Traub. 1963. Notas sobre sifonápteros. X. Descripción de Strepsylla machadoi nov. sp. (Siph., Hystrichops., Neops.). Ciencia 22:191-196. 
Barrera, A., ANd R. Traub. 1967. Phalacropsylla nivalis a new species of flea from México (Siphonaptera, Hystrichopsyllidae). Anales de la Escuela Nacional de Ciencias Biológicas 14:35-46.

Bassols, I. 1981. Catálogo de los ácaros Mesostigmata de mamíferos de México. Anales de la Escuela Nacional de Ciencias Biológicas 24:9-49.

Bassols B., I. R. LiRAY, ANd S. RamiRez. 1976. Los representantes del género Hirstionyssus in México (Acarina, Mesostigmata, Laelapidae, Hirstionyssinae). XI. Congreso Nacional de Entomología Folia Entomologica Mexicana 38:103.

Bassols-Batalla, I., M. T. Quintero-Martinez, J. A. MorenoMoreno, and T. Vessi-Lobato. 1991. Acaros del género Hirstionyssus Fonseca en México, con descripción de una nueva especie (Mesostigmata, Laelapidae). Anales de la Escuela Nacional de Ciencias Biológicas 34:145-157.

Bassols de Barrera, I. 1970. Nuevos datos sobre Gigantolaelaps Fonseca, 1939 (Acarina: Dermanyssidae: Laelapinae). Anales de Escuela Nacional de Ciencias Biológicas 17:55-63.

Bell, K. C., C. J. Carlson, and A. J. Phillips. 2018. Parasite collections: overlooked resources for integrative research and conservation. Trends in Parasitology 34:637-639.

Bochrov, A. V., And C. Guzmán-Cornejo. 2014. Mites of the subgenus Neotomobia n. subg. (Acariformes: Myobiidae: Radfordia), parasites of the subfamily Neotominae (Rodentia: Cricetidae). Systematic Parasitology 89:91-100.

Bradley, R. D., AND M. R. Mauldin. 2016. Molecular data indicate a cryptic species in Neotoma albigula (Cricetidae: Neotominae) from northwestern Mexico. Journal of Mammalogy 97:187-199.

Brennan, J. M. 1960a. Ectonyx, a new neotropical genus of chiggers (Acarina: Trombiculidae). Acarologia 2:88-91.

Brennan, J. M. 1960b. Eight new species of Pseudoschoengastia from Mexico and Panama with a revised key to the species (Acarina:Trombiculidae). Acarologia 2:480-492.

Brennan, J. M. 1962. Four new chiggers from Mexico. Journal of Parasitology 48:618-620.

BRennan, J. M. 1966. New records of chiggers (Acarina: Trombiculidae) from Baja California and islands of the Gulf of California. Journal of Parasitology 52:772-775.

Brennan, J. M., And H. C. Dalmat. 1960. Chiggers of Guatemala (Acarina: Trombiculidae). Annals of the Entomological Society of America 53:183-191.

Brennan, J. M., AND E. K. Jones. 1959. Pseudoschoengastia and four new Neotropical species of the genus (Acarina: Trombiculidae). Journal of Parasitology 45:421-429.

Brumpt, E., L. Mazzotti, and L. C. Brumpt. 1939. Étude épidemiologique de la fiévre récurrente endémique des hauts plateau Mexicains. Annales de Parasitologie Humaine et Comparée 17:275-286.

Burgin, C. J., J. P. Colella, P. L. Kahn, and N. S. Upham. 2018. How many species of mammals are there? Journal of Mammalogy 99:1-14.

Camargo, I., E. Romero-Callejas, C. Cornejo-Latorre, E. Rios, and S. T. Álvarez-Castañeda. 2017. Prevalence and intensity of flea Tunga monositus (Siphonaptera) in an insular population of Peromyscus maniculatus (Rodentia) from northwest Mexico. Mammalia 81:429-432.

Ceballos, G. (ed). 2014. Mammals of Mexico. Johns Hopkins University Press. Baltimore, U.S.A.
Ceballos, G., And J. Arroyo-Cabrales. 2012. Lista actualizada de los mamíferos de México 2012. Revista Mexicana de Mastozoología, Nueva Época 2:27-80.

Cooley, R. A., AND G. M. Kohls. 1942. Ixodes mexicanus n. sp. e. Ixodes tancitarius s. sp. dos nuevas garrapatas mexicanas (Acarina, Ixodidae). Revista de la Sociedad Mexicana de Historia Natural 3:149-154.

Cooley, R. A., AND G. M. Kohls. 1944. The Argasidae of North America, Central America and Cuba. American Midland Naturalist Monograph No. 1. The University Press. Notre Dame, U.S.A.

Cook. E. F. 1954. A technique for preventing post-mortem ectoparasite contamination. Journal of Mammalogy 35:266-267.

Cook, J. A., S. Greiman, S. Agosta, R. P. Anderson, B. S. Arbogast, R. J. Baker, W. Boeger, R. D. Bradley, D. R. Brooks, R. Cole, J. R. Demboski, A. P. Dobson, J. L. Dunnum, R. P. Eckerlin, J. Esselstyn, K. Galbreath, J. Hawdon, H. Hoekstra, S. Kutz, J. E. Light, L. Olson, B. D. Patterson, J. L. Patton, A. J. Phillips, E. Rickart, D. S. Rogers, M. E. Siddall, V. TKACH, AND E. P. HoBERG. 2016. Transformational principles for NEON sampling of mammalian parasites and pathogens: a response to Springer and colleagues. BioScience 66:917-919.

Сook, J. A., K. E. Galbreath, K. C. Bell, M. L. Campbell, S. Carrière, J. P. Colella, N. G. Dawson, J. L. Dunnum, R. P. Eckerlin, S. E. Greiman, V. Fedorov, G. M. S. Hass, V. Haukisalmi, H. Henttonen, A. G. Hope, D. Jackson, T. Jung, A. V. Koehler, M. Kinsella, D. Krejsa, S.J. Kutz, S. Liphardt, S. O. MacDonald, J. L. Malaney, A. Makarikov, J. Martin, B. S. Mclean, R. Mulders, B. Nyamsuren, S. L. Talbot, V. V. TKach, A. Tsvetkova, H. M. Toman, E. C. Waltari, J. L. Whitman, and E. P. Hoberg. 2017. The Beringian coevolution project: Holistic collections of mammals and associated parasites reveal novel perspectives on evolutionary and environmental change in the north. Arctic Science 3:585-617.

Cook, J. A. AND J. E. Light. 2019. The emerging role of mammal collections in 21st century mammalogy. Journal of Mammalogy 100:733-750.

Damp, A. 1942. Nuevos datos sobre la pulga Pleochatis mundus (Jordan y Rothschild 1922). Revista de la Sociedad Mexicana de Historia Natural 3:135-148.

Davis, G. E. 1943. Studies on the biology of the argasid tick, Ornithodoros nicollei Mooser. Journal of Parasitology 20:393395.

Durden, L. A., AND G. G. Musser. 1994a. The sucking lice (Insecta, Anoplura) of the world: a taxonomic checklist with records of mammalian hosts and geographical distributions. Bulletin of the American Museum of Natural History 218:1-90.

Durden, L. A., AND G. G. Musser. 1994b. The mammalian hosts of the sucking lice (Anoplura) of the world: a host-parasite list. Bulletin of the Society for Vector Ecology 19:130-168.

EAds, R. B. 1951. A new species of Jellisonia Traub from Mexico (Ceratophyllidae, Siphonaptera). Journal of Parasitology 37:147-150.

EAds, R. B., AND M. Borom. 1975. Host and distributional records for the tick Amblyomma inornatum (Banks; Acarina: Ixodidae), with descriptions of immature stages. Journal of Medical Entomology 12:493-496.

Eckerlin, R. P. 2005. Fleas (Siphonaptera) of the Yucatan Peninsula (Campeche, Quintana Roo, and Yucatan), Mexico. Caribbean Journal of Science 41:152-157. 
Emerson, K. C. 1971. New records of Anoplura from Mexico. Journal of the Kansas Entomological Society 44:374-377.

Estébanes-Gonzáles, M. L., And F. A. Cervantes. 2005. Mites and ticks associated with some small mammals in Mexico. International Journal of Acarology 31:23-37.

Estébanes-González, M. L., C. Sánchez-Hernández, M. de L. Romero-Almaraz, and G.D. Schnell. 2011. Ácaros parásitos de roedores de Playa de Oro, Colima, México. Acta Zoológica Mexicana 27:169-176.

Fain, A. 1969. Les deutonymphes hypopiales vivant en association phoretique sur les mammiferes (Acarina: Sarcoptiformes). Bulletin de I'Institut royal des Sciences Naturelles de Belgique 45:1-262.

Fain, A. 1970. Diagnose de nouveaux Lobalgides et Listrophoroides (Acarina: Sarcoptiformes). Revue de Zoologie et de Botanique Africaine 81:271-300.

Fain, A., AND M. L. Estébanes. 2000. Notes on the fur mites of the genus Geomylichus Fain, 1970 (Acari Astigmata Listrophoridae), with description of a new species from Mexico. Bulletin Société royale belge d'Entomologie/Koninklijke Belgische Vereniging voor Entomologie 136:53-59.

Fain, A., And K. Hyland. 1974. The listrophoroid mites in North America II. The family Listrophoridae Megnin and Trouessart (Acarina: Sarcoptiformes). Bulletin de l'Institut royal des Sciences Naturelles de Belgique Entomologie 50:1-69.

Fain, A., AND G. S. IDE. 1978. A new hypopus, Dermacarus liomys sp. n. (Acari: Glycyphagidae) from a Mexican rodent, Liomys irroratus. International Journal of Acarology 4:233-234.

Fain, A., AND F. S. Lukoschus. 1978. New endofollicular or subcutaneous hypopi from mammals (Acarina: Astigmata). Acarologia 19:484-493.

Fain, A., AND J. O. Whitaker, JR. 1987. New observations on the genus Geomylichus Fain, 1970 (Acari, Listrophoridae) with description of four new species and a new subgenus. International Journal of Acarology 13:15-28.

Fain, A., J. O. Whitaker JR., AND H. H. Thomas. 1978. Two new species of Geomylichus (Acari: Listrophoridae) from California, U.S.A. International Journal of Acarology 14:121-125.

Fain, A., J. O. Whitaker, JR., AND H. H. Thomas. 1991. Two new fur mites of the genus Geomylichus Fain, 1970 (Acari: Listrophoridae) from kangaroo rats, from U.S.A. International Journal of Acarology 17:175-180.

Falcón-Ordaz, J., R. Acosta, J. A. Fernández, and G. LiraGuerRero. 2012. Helmintos y sifonápteros parásitos de cinco especies de roedores en localidades de la Cuenca Oriental, en el Centro de México. Acta Zoológica Mexicana 28:287-304.

Fernández, J. A., ANd R. Acosta. 2005. First record of fleas (Insecta: Siphonaptera) from Nelson's kangaroo rat, Dipodomys nelsoni (Rodentia : Heteromyidae) in Durango, Mexico. Journal of the New York Entomological Society 113:230-232.

Fernández, J. A., F. A. Cervantes, and M. S. Hafner. 2012. Molecular systematics and biogeography of the Mexican endemic kangaroo rat, Dipodomys phillipsii (Rodentia: Heteromyidae). Journal of Mammalogy 93:560-571.

Fernández, J. A., M. S. Hafner, D. J. Hafner, and F. A. Cervantes. 2014. Conservation status of rodents of the families Geomyidae and Heteromyidae of Mexico. Revista Mexicana de Biodiversidad 85:576-588.
Fernández-González, A. M., M. Y. Kosoy, A. V. Rubio, C. B. Graham, J. A. Montenierı, L. M. Osikowicz, Y. Bal, R. Acosta-Gutiérrez, R. Ávila-Flores, K. L. Gage, And G. Suzán. 2016. Molecular Survey of Bartonella Species and Yersinia pestis in rodent fleas (Siphonaptera) from Chihuahua, Mexico. Journal of Medical Entomology 53:199-205.

FerRIS, G. F. 1921. Contributions towards a monograph of the sucking lice. Part II. Stanford University Publications, Biological Sciences 2:52-133.

FerRIS, G. F. 1922. Contributions towards a monograph of the sucking lice. Part III. Stanford University Publications, Biological Sciences 2:134-178.

FerRIS, G. F. 1923. Contributions towards a monograph of the sucking lice. Part IV. Stanford University Publications, Biological Sciences 2:179-270.

FerRIS, G. F. 1942. Some North American rodent-infesting lice (Insecta: Anoplura). Microentomology 7:84-90.

Ferris, G. F. 1951. The sucking lice. Memoirs of the Pacific Coast Entomological Society 1:1-320.

Fox, I. 1939. New species and records of Siphonaptera from México. lowa State College Journal of Science 13:335-339.

Furman, D. P. 1955a. Steptolaelaps (Acarina: Laelapidae) a new genus of mites parasitic on neotropical rodents. Journal of Parasitology 41:519-525.

Furman, D. P. 1955b. Revision of the genus Eubrachylaelaps (Acarina: Laelaptidae) with the descriptions of two new species from Mexico. Annals of the Entomological Society of America 48:51-59.

Gardner, S. L. 1996. Essential techniques for collection of parasites during surveys of mammals. Pp. 291-298 in Measuring and monitoring biological diversity-standard methods for mammals (Wilson, D. E., F. R. Cole, J. D. Nichols, R. Rudran, and M. S. Foster, eds.), Smithsonian Institution Press, Washington, D.C., U.S.A.

Genoways, H. H. 1973. Systematics and evolutionary relationships of spiny pocket mice, genus Liomys. Special Publication Museum Texas Tech University 5:1-368.

Goff, M. L., AND R. B. Loomis. 1973. Two new species of Odontacarus Ewing (Acarina: Trombiculidae) from California and Baja California, Mexico. Journal of Medical Entomology 19:333-336.

Goff, M. L., AND R. B. Loomis. 1977. The genus Odontacarus (Acari: Trombiculidae) from North America. Journal of Medical Entomology 14:370-372.

Gómez-Ródríguez, R. A., G. Gutiérrez-Granados, G. MontielParra, A. Rodríguez-Moreno, and V. Sánchez-Cordero. 2015. Diversity and coexistence of ectoparasites in small rodents in a tropical dry forest. Biotropica 47:484-490.

Grant, C. D. 1947. North American species of the genus Laelaps (Arachnida: Acarina: Parasitidae). Microentomology 12:2-21.

Gutiérrez-Velázquez, A. L., ANd R. Acosta. 2004. Relaciones biogeográficas basadas en la distribución de Siphonaptera (Insecta). Pp. 393-416 in Biodiversidad de la Sierra Madre Oriental (Luna, I., J. J. Morrone, and D. Espinosa, eds.). Las Prensas de Ciencias. Ciudad de México, México.

Guzmán-Cornejo, C., R. G. Robbins, and T. M. Pérez. 2007. The Ixodes (Acari: Ixodidae) of Mexico: parasite-host and hostparasite checklists. Zootaxa 1553:47-58. 
Guzmán-Cornejo, C., R. G. Robbins, A. A. Guglielmone, G. Montiel-Parra, and T. M. Pérez. 2011. The Amblyomma (Acari, Ixodida, Ixodidae) of Mexico: identification keys, distribution and hosts. Zootaxa 2998:16-38.

Guzmán-Cornejo, C., R. G. Robbins, A. A. Guglielmone, G. MontielParra, G. Rivas, And T. M. Pérez. 2016. The Dermacentor (Acari, Ixodida, Ixodidae) of Mexico: hosts, geographical distribution and new records. Zookeys 569:1-22.

Hastriter, M. W. 1997. Establishment of the tungid flea, Tunga monositus (Siphonaptera: Pulicidae), in the United States. Great Basin Naturalist 57:281-282.

Hastriter, M. W. 2004. Revision of the flea genus Jellisonia Traub, 1944 (Siphonaptera: Ceratophyllidae). Annals of Carnegie Museum 73:213-238.

Herrin, C. S. 1970. A systematic revision of the genus Hirstionyssus (Acari: Mesostigmata) of the Nearctic region. Journal of Medical Entomology 10:391-437.

HoberG, E. P. 2002. Foundations for an integrative parasitology: collections, archives, and biodiversity informatics. Comparative Parasitology 69:124-131.

Hoffmann, A. 1950. Contribuciones al conocimiento de los trombicúlidos mexicanos (Acarina: Trombiculidae (2a parte). Ciencia, México 10:148-153.

Hoffmann, A. 1951a. Contribuciones al conocimiento de los trombicúlidos Mexicanos (Acarina: Trombiculidae; 3a parte). Ciencia, México 11:29-36.

Hoffmann, A. 1951b. Contribuciones al conocimiento de los trombicúloidos Mexicanos (Acarina:Trombiculidae; 4a parte). Ciencia, México 11:97-103.

Hoffmann, A. 1952. Contribuciones al conocimiento de los trombicúlidos mexicanos (Acarina: Trombiculidae (5a parte). Ciencia, México 12:87-94.

Hofrmann, A. 1954. Contribuciones al conocimiento de los trombicúlidos Mexicanos (Acarina: Trombiculidae; 6a parte). Anales de la Escuela Nacional de Ciencias Biológicas 8:17-30.

Hoffmann, A. 1960a. Una nueva especie mexícana del género Trombicula (Acarina: Trombiculidae). Pp. 555-558 in Libro Hom. Doctor Eduardo Caballero y Caballero. Instituto Politécnico Nacional. Ciudad de México, México

Hoffmann, A. 1960b. Contribuciones al conocimiento de los trombicúloidos Mexicanos (Acarina: Trombiculidae; 8a parte). Ciencia 20: 99-105.

Hoffmann, A. 1960c. Contribuciones al conocimiento de los trombicúloidos Mexicanos (Acarina:Trombiculidae; 9a parte). Acta Zoológica Mexicana 4:1-10.

Hoffmann, A. 1962. Monografía de los Ixodoidea de México. Parte I. Revista de la Sociedad Mexicana de Historia Natural 23:191-307.

Hoffmann, A. 1963. Contribuciones al conocimiento de los trombicúlidos mexicanos (Acarina: Trombiculidae (10a parte). Anales de la Escuela Nacional de Ciencias Biológicas 12:101-109.

Hoffmann, A. 1965. Contribuciones al conocimiento de los trombicúlidos mexicanos (Acarina: Trombiculidae (11a parte) Folia Entomologica Mexicana 9:3-18.

Hoffmann, A. 1990. Los trombiculidos de México (Acarida: Trombiculidae). Publicaciones especiales, Universidad Nacional Autónoma de México 2:1-275.
Hoffmann, A., And R. Servín. 1990. Una especie nueva de listroforido asociado a un roedor de Baja California Sur. The Southwestern Entomologist 15:333-308.

Hoffmann, A., I. B. De Barrera, And C. Méndez. 1972. Nuevos hallazgos de ácaros en México. Revista del Sociedad Mexicana de Historia Natural 33:151-159.

Hoffmann, A., M. OJeda, And G. López. 1989. Los ectosimbiontes de Peromyscus difficilis (J.A. Allen, 1891; Rodentia: Cricetidae). Revista de la Sociedad Mexicana de Historia Natural 40:49-58.

Holland, G.P. 1965. Newspeciesand subspeciesofAnomiopsyllus Baker from México (Siphonaptera: Hystrichopsyllidae). The Canadian Entomologist 97:1051-1058.

Holland, G. P. 1971. New Siphonaptera from southern México. The Canadian Entomologist 103:95-104.

Hopkins, G. H. E., AND M. RothschiLd. 1962. An Illustrated Catalogue of the Rothschild Collection of Fleas (Siphonaptera) in the British Museum (Nat. Hist.) Vol. 3. Hystrichopsyllidae. British Museum (Nat. Hist.), London, United Kingdom.

Hopkins, G. H. E., AND M. Rothschild. 1966. An Illustrated Catalogue of the Rothschild Collection of Fleas (Siphonaptera) in the British Museum (Nat. Hist.) Vol. 4 Hystrichopsyllidae. British Museum (Nat. Hist.), London, U.K.

Hopkins, G. H. E., AND M. Rothschild. 1971. An Illustrated Catalogue of the Rothschild Collection of Fleas (Siphonaptera) in the British Museum (Nat. Hist.) Vol. 5 Leptopsyllidae and Ancistropsyllidae. British Museum (Nat. Hist.), London, U.K.

Hubbard, C. A. 1958. Mexican jungle and desert fleas with three new descriptions. Entomological News 69:161-166.

Jameson, E. W. 1951. Eubrachylaelaps martini, a new mite (Acarina: Laelaptinae) from the volcano mouse (Mammalia: Cricetinae). Journal of Parasitology 37:556-559.

Jameson, E. W. 1952. Euhaemogamasus keegani, new species, a parasitic mite from Western North America (Acarina: Laelaptidae: Haemogamasinae). Annals of the Entomological Society of America 45:600-604.

Johnson, P. T. 1962. The species of Fahrenholzia Kellogg and Ferris from spiny pocket mice (Anoplura: Hoplopleuridae). Annals of the Entomological Society of America 55:415-428.

Johnson, P. T., And R. Traub. 1954. Revision of the flea genus Peromyscopyslla. Smithsonian Miscellaneous Collections 123:1-68

JoRDAN, K. 1925. New Siphonaptera. Novitates Zoologicae 32:96-112.

Keirans, J. E., And E. K. Jones. 1972. Description of the immature stages of Ixodes ( $I$.) sinaloa Kohls and Clifford (Acarina: Ixodidae), from rodents in Mexico and Nicaragua. Acarologia 13:471-475.

Kıм, K. C. 1965. A review of the Hoplopleura hesperomydis complex (Anoplura: Hoplopleuridae). Journal of Parasitology 51:871-887.

Kım, K. C., H. D. Pratt, and C. J. Stojanovich. 1986. The sucking lice of North America: An illustrated manual for identification. The Pennsylvania State University Press. University Park, U.S.A.

Kohts, G. M., AND C. M. Clifford. 1966. Three new species of Ixodes from Mexico and description of the male of I. auritulus auritulus Neumann, I. conepati Cooley and Kohls, and I. Iasallei Mendez and Ortiz (Acarina: Ixodidae). Journal of Parasitology 52:810-820. 
Kohls, G. M., D. E. Sonenshine, And C. M. Clifford. 1965. The systematics of the subfamily Ornithodorinae (Acarina: Argasidae). II. Identification of the larvae of the Western Hemisphere and descriptions of three new species. Annals of the Entomological Society of America 58:331-364.

Light, J. E., And M. S. Hafner. 2007. Phylogenetics and host associations of Fahrenholzia sucking lice (Phthiraptera: Anoplura). Systematic Entomology 32:359-370.

Linardi, P.M., And D. Moreira de Avelar. 2014. Neosomes of tungid fleas on wild and domestic animals. Parasitology Research 113:3517-3533.

Loomis, R. B. 1956. The chigger mites of Kansas (Acarina: Trombiculidae). University of Kansas Science Bulletin 37:1195-1443.

Loomis, R. B. 1969. Chiggers (Acarina, Trombiculidae) from vertebrates of the Yucatan Peninsula, Mexico. University of Kansas Museum of Natural History Publications 50:1-22.

Loomis, R. B. 1971. The genus Euschoengastoides (Acarina: Trombiculidae) from North America. Journal of Parasitology 57:689-707.

Loomis, R. B., AND M. Bunnell. 1962. A new species of chigger, genus Euschoengastia (Acarina, Trombiculidae), with notes on other species of chiggers from the Santa Ana Mountains, California. Bulletin of the Southern California Academy of Science 61:177-184.

Loomis R. B., AND D. A. Crossley, JR. 1963. New species and new records of chiggers (Acarina: Trombiculidae) from Texas. Acarologia 5:371-383.

Loomis, R. B., AND M.L. Goff. 1973. A new genus and two new species of North American Leeuwenhoekiinae chiggers (Acarina, Trombiculidae). Journal of Medical Entomology 10:113-117.

Loomis, R. B., AND J. L. Lucas. 1970. A new subgenus and two new species of Hexidionis (Acarina: Trombiculidae) from North America. Bulletin of the Southern California Academy of Science 69:52-59.

Loomis, R. B., And R. E. Somerby. 1966. New species and new records of Euschoengastia (Acarina, Trombiculidae) from Western Mexico. Bulletin of the Southern California Academy of Science 65:211-224.

Loomis, R. B., AND J. P. WebB, JR. 1969. A new species of Speleocola (Acarina: Trombiculidae), off a bat, Pizonyx vivesi, from Baja California, Mexico. Bulletin of the Southern California Academy of Science 68:36-42.

Loomis, R. B., AND J. P. WebB, JR. 1972. A new species of Microtrombicula (Acarina: Trombiculidae) from Hidalgo, Mexico. Bulletin of the Southern California Academy of Science 71:159-161.

Loomis, R. B., ANd W. J. WrenN. 1973. The North American genus Otorhinophila Wrenn and Loomis (Acarina: rombiculidae), with the descriptions of three new species. Journal of Parasitology 59:175-182.

LucAs, J. L., AND R. B. Loomis. 1968. The genus Hexidionis (Acarina: Trombiculidae) with the description of a new species from western Mexico. Bulletin of the Southern California Academy of Science 67:233-239.

Machado-A. C. E. 1960. Microtus mexicanus mexicanus (De Santssate, 1861). Su biología ectoparásitos y otras formas animale ecológicamente relacionadas. Tesis profesional. Facultad de Ciencias, UNAM.
MatocQ, M. D. 2002. Morphological and molecular analysis of a contact zone in the Neotoma fuscipes species comples. Journal of Mammalogy 83:866-883.

Mazzottı, L. 1943. Una nueva especie de Ornithodoros en México. Revista del Instituto Salubridad y Enfermedades Tropicales 4:371-373.

Mazzotri, L. 1949. Sobre una nueva espiroqueta de la fiebre recurrente encontrada en México. Revista del Instituto de Salubridad y Enfermedades Tropicales 10:227-281.

Méndez-L. J. 1974. Composición específica y fluctuación del número de sifonápteros en una población local de Microtus m. mexicanus (Saussure; INS.: SIPH.: MAMM.; CRICET.). Tesis doctoral. Facultad de Ciencias UNAM.

Montiel-Parra, G., H. Fuentes-Moreno, and M. Vargas. 2007. Primer registro de Ixodes cookei (Acari: Ixodidae) para Mexico. Revista Mexicana de Biodiversidad 78:205-206.

Morales-Muciño, J. C., AND J. Llorente-Bousquets. 1985. Estado actual del conocimiento de los Siphonaptera de Mexico. Anales del Instituto de Biología Universidad Nacional Autónoma de México 56:497-554.

Morales, J. C., AND J. Llorente. 1986. Estado actual del conocimiento de los Siphonaptera de México. Anales del Instituto de Biología, UNAM, Serie Zoología 2:497-554.

Morlan, H. B., AND C. C. Hoff. 1957. Notes on some Anoplura from New Mexico and Mexico. Journal of Parasitology 43:347-351.

Morrone, J. J., R. Acosta, ANd A. L. Gutiérrez. 2000. Cladistics, biogeography, and host relationships of the flea subgenus Ctenophthalmus (Alloctenus), with the description of a new Mexican species (Siphonaptera: Ctenophthalmidae). Journal of the New York Entomological Society 108:1-12.

Muñiz, A. M., J. C. Morales-Muciño, R. Ayalá- Barajas, and J. Llorente-Bousquets. 1981. Primera lista de tipos depositados en el Museo de Zoología "Alfonso L. Herrera" de la Facultad de Ciencias de la Universidad Autónoma de México: Colección de insectos ectoparásitos "Alfredo Barrera". Folia Entomológica Mexicana 49:155-168.

Patton J. L., and S. T. Álvarez-Castañeda. 1999. Family Heteromyidae. Pp. 351-442 in Mamíferos del Noroeste de México (Álvarez-Castañeda S. T., and J. L. Patton, eds.). Centro de Investigaciones Biológicas del Noroeste, SC. La Paz, Mexico.

Patton, J. L., D. G. Huckaby, and S. T. Álvarez-Castañeda. 2007. The systematic and evolutionary history of woodrats of the Neotoma lepida complex. University of California Press 135:1-411.

Pence, D. B., And H. H. Genoways. 1974. Neolabidophorus yucatanensis gen. et sp. n. and a new record for Dermacarus ornatus Fain, 1967 (Acarina: Gllycyphagidae) from Heteromys gaumeri Allen and Chapman, 1897, Gaumer's spiny pocket mouse (Rodentia: Heteromyidae). Journal of Parasitology 60: 712-715.

Peniche-Lara, G., K. Dzul-Rosado, C. Pérez-Osorio, and J. ZavalaCAStro. 2015. Rickettsia typhi in rodents and $R$. felis in fleas in Yucatan as a possible causal agent of undefined febrile cases. Revista do Instituto de Medicina Tropical de Sao Paulo 57:129-132.

Pérez-Ortiz, T. M. 1976. Distribución de Siphonaptera en el Derrame Lávico del Chichinautzin, Morelos: Su interpretación ecológica y biogeográfica. Tesis Profesional. Facultad de Ciencias, UNAM. 
Pomeroy, L. V., AND R. B. Loomis. 1984. A new genus of trombiculine chiggers (Acari: Trombiculidae) from western North America. Journal of Medical Entomology 21:268-273.

Ponce-Ulloa, H. E., AND J. E. Llorente-Bosquets. 1996. Siphonaptera. Pp. 553-565 in Biodiversidad, Taxonomía y Biogeografía de Artrópodos de México: hacia una síntesis de su conocimiento (Llorente-Bousquets, J., A. N. García Aldrete, and E. González Soriano, eds.). Universidad Nacional Autónoma de México, Instituto de Biología. Ciudad Universitaria, Ciudad de México, México.

Porter, C. A., N. E. Beasley, N. Ordoñez-Garza, L. L. Lindsey, D. S. Rogers, N. Lewis-Rogers, J. W. Sites, and R. D. Bradley. 2017. A new species of big-eared climbing rat, genus Ototylomys (Cricetidae: Tylomyinae), from Chiapas, Mexico. Journal of Mammalogy 98:1310-1329.

Preisser, W. C., and J. Falcón-Ordaz. 2019. A checklist of the parasitic helminthes of cricetid and heteromyid rodents in Mexico. Therya 10:329-341.

Quintero, M. T., M. Vargas, B. S. Hernández, P. García, and N. J. Otero. 2001. Ectoparasitic mites on Heteromys guameri in the south of Yucatán, Mexico. Pp. 583-585 in Acarology (Halliday, R. B., D. E. Walter, H. C. Proctor, R. A. Norton, and M. J. Colloff, eds). Proceedings of the $10^{\text {th }}$ International Congress, Commonwealth Scientific and Industrial Research Organisation. Melbourne, Australia.

Radovsky, F. J. 1960. Haemogamasus liponyssoides hesperus n. ssp. With a discussion of the $\mathrm{H}$. liponyssoides complex (Acarina: Haemogamasidae). Journal of Parasitology 46:401-409.

Ramírez, S. 1982. Distribución altitudinal de los ácaros mesostigmados y los sifonápteros de roedores en el campo experimental forestall "San Juan Tetla" Puebla México. Tesis professional. Facultad de Ciencias, UNAM.

Ramírez, V. S., I. Bassols B., and S. A. Santillán. 1980. Hirstionyssus (Acarina: Mesostigmata) del volcán Iztaccíhuatl, México. Folia Entomológica Mexicana 44:157-167.

Ramírez-Pulido, J., N. González-Ruiz, A. L. Gardner, And J. Arroyo-Cabrales. 2014. List of recent land mammals of Mexico, 2014. Special Publications of the Museum of Texas Tech University 63:1-69.

Ramos-Casillas, F. 2003. Detección de Rickettsia typhi (Rickettsiales: Rickettsiaceae) en roedores y vectores relacionados en el noreste de México. M. Sc. Thesis. Facultad de Ciencias Biológicas, Universidad Autónoma de Nuevo León, San Nicolás de los Garza, Nuevo León.

Ridde, B. R., D. J. Hafner, And L. F. Alexander. 2000. Comparative phylogeography of Baileys' pocket mouse (Chaetodipus baileyi) and the Peromyscus eremicus species group: historical vicariance of the Baja California Peninsular Desert. Molecular Phylogenetics and Evolution 17: 61-172.

Rıos E., And S. T. Álvarez-Castañeda. 2013. Nomenclatural change of Chaetodipus dalquesti. Western North America Naturalist 73:399-400.

Robbins, R. G., AND J. E. Keirans. 1987. Ixodes (Ixodiopsis) woodi (Acari: Ixodidae): description of the larva and redescription of the nymph. Journal of Medical Entomology 24:310-314.

Robbins, R. G., AND J. E. Keirans. 1992. Systematics and ecology of the subgenus Ixodiopsis (Acari: Ixodidae: Ixodes). Thomas Say Foundation Monograph No. XIV, Entomological Society of America. Lanham, U.S.A.
Rogers, D. S., R. N. Leite, And R. J. Reed. 2011. Molecular phylogenetics of an endangered species: the Tamaulipan woodrat (Neotoma angustapalata). Conservation Genetics 12:1035-1048.

Rrckman, R. E., AND J. C. Roos. 1955. Chiggers associated with squamous papillomata on a Perognathus mouse. Journal of Parasitology 41:639.

Salceda-Sánhez, B., And M. W. Hastriter. 2006. A list of the fleas (Siphonaptera) of Mexico with new host and distribution records. Zootaxa 1296:29-43.

Sánchez-Montes, S., C. Guzmán-Cornejo, L. León-Paniagua, and G. RIvAs. 2013. A checklist of sucking lice (Insecta: Phthiraptera: Anoplura) associated with Mexican wild mammals, including geographical records and a host-parasite list. Zootaxa 3722:183-203.

Sánchez-Montes, S., C. Guzmán-Cornejo, G. Herrera-Montalvo, A. D. Richman, J. J. Flores-Martínez, G. F. García-Ruiz, M. Berzunza-Cruz, P. Gaytán-Colin, R. Pérez-Montfort, V. E. Alcántara-Rodriguez, and I. Becker. 2016a. First record of Bartonella vinsonii in the sucking louse Hoplopleura hirsuta collected from hispid cotton rats, Sigmodon hispidus, in Mexico. Southwestern Entomologist 41:1031-1036.

Sánchez-Montes, S., C. Guzmán-Cornejo, F. Ramírez-Corona, and L. León-Paniagua. 2016b. Anoplurans (Insecta: Psocodea: Anoplura) associated with rodents distributed in the neotropical region of Mexico. Revista Mexicana de Biodiversidad 87:427-435.

Sánchez-Montes, S., P. Colunga-Salas, L. Álvarez-Castillo, C. Guzmán-Cornejo, and G. Montiel-Parra. 2018. Chewing lice (Insecta: Phthiraptera) associated with vertebrates in Mexico. Zootaxa 4372:1-109.

Sandoval, D., A. Perez-Miravelli, And A. Barrera. 1962. Hallazgo de una cepa de Pasteurella pestis en Microtus capturado en la ciudad de México. Revista Latinoamericana de Microbiología 5:55-60.

Servín, R., R. Aguilar, and S. T. Álvarez-Castañeda. 1992. New species of the genus Geomylichus (Acarida, Listrophoridae) Fain 1970 on Cerralvo Island (Baja-California Sur, Mexico). Southwestern Entomologist 17:341-345.

Servín, R., R. Aguilar, and S. T. Álvarez-Castañeda. 1994. A species of the genus Geomylichus Fain 1970 (Acarida, Listrophoridae), present in an endemic rodent population of Baja California Sur (Mexico). Southwestern Entomologist 19:285-289.

Sмiт, F. G. A. M. 1987. An illustrated catalog of the Rothschild collection of fleas (Siphonaptera) in the British Museum (Natural History). Volume VII. Oxford University Press. Oxford, U.K.

Sullivan, R. M., AND T. L. Best. 1997. Systematics and morphologic variation in two chromosomal forms of the agile kangaroo rate (Dipodomys agilis). Journal of Mammalogy 78:775-797.

StaRK, H. E. 1970. A revision of the flea genus Thrassis Jordan 1933 (Siphonaptera: Ceratophyllidae) with observations on ecology and relationships to plague. University of California Publications in Entomology 53:184.

TANigoshi, L. K., AND R. B. Loomis. 1974. The genus Hyponeocula (Acarina: Trombiculidae) of western North America. Melanderia 17:1-27.

Tujerina Medina, G., J. M. Torres, V. A. Rodríguez-Castro, H. Quiroz-Martinez, and J. I. González-Rojas. 2006. Fleas 
(Siphonaptera) and ticks (Arachnida: Acari: Ixodida) parasitizing small mammals in the Sierra San Antonio Pena Nevada, State of Nuevo Leon, Mexico. Entomological News 117:95-100.

Tıмm, R. M. 1985. Parasites. Pp. 455-534 in Biology of New World Microtus (Tamarin, R. H. ed.). Special Publications No. 8, The American Society of Mammalogists. Lawrence, U.S.A.

Tipton, V. J., And E. Mendez. 1968. New species of fleas (Siphonaptera) from Cerro Potosi, Mexico, with notes on ecology and host parasite relationships. Pacific Insects 10:177-214.

Traub, R. 1944. New North American fleas. Field Museum of Natural History, Zoological Series 29:211-220.

Traub, R. 1950. Siphonaptera from Central America and Mexico. A morphological study of the aedeagus with descriptions of new genera and species. Fieldiana Zoology Memoir, Chicago Natural History 1:1-127.

Traub, R., and C. C. Hoff. 1951. Records and descriptions of fleas from New Mexico. American Museum Novitates 1530:1-23.

Traub, R., And P. T. Johnson. 1952a. Atyphloceras tancitari and Jellisonia bonia, new species of fleas from México (Siphonaptera). American Museum Novitates 1558:1-19.

Traub, R., AND P. T. Johnson. 1952b Four new species of fleas from México (Siphonaptera). American Museum Novitates 1598:1-28.

Traub, R., and P. T. Johnson. 1952c. Kohlsia whartoni and Stenoponia ponera, new species of fleas from North America. Journal of Parasitology 38:6-18.

Traub, R., And A. Barrera. 1955. Three new fleas of the genus Strepsylla Traub (Siphonaptera: Hystrichopsyllidae). Fieldiana Zoology Memoir 37:541-550.

Traub, R., M. Rothschild, and J. F. Haddow. 1983. The Ceratophyllidae: key to the genera and host relationships with notes on their evolution, zoogeography and medical importance. Pp. 42-228 in The Rothschild collections of fleas. (Miriam Rothschild and Robert Traub, eds.). Cambridge University Press, London, U.K.

VARGAS, L. 1951a. Notas sobre una pulga mexicana Koh/sia fournieri n. sp. (Insecta: Suctoria). La Prensa Médica Mexicana 16:169-171.

VARGAS, L. 1951b. Nota sobre la pulga Polygenis vazquezi $\mathrm{n}$. sp. de México. Medicina 31:461-464.

VARGAS, L. 1951c. Jellisonia ortizi n. sp. pulga ceratofilida de México. Revista del Instituto de Salubridad y Enfermedades Tropicales 12:81-87.

Vargas, L. 1951d. Polygenis martinezbaezi n. sp. de México (Insecta: Suctoria). Revista del Instituto de Salubridad y Enfermedades Tropicales 12:107-111.

VarGas, L. 1951e. Notas acerca de las pulgas mexicanas (Insecta: Suctoria). Revista del Instituto de Salubridad y Enfermedades Tropicales 12:81-87.

Vargas, L. 1952. Pulgas de México Polygenis rozeboomi n. sp. Boletín de la Oficina Sanitaria Panamericana 32:515-520.

VARGAS, L. 1960. Orchopeas reevesi n. sp. de Sonora, México (Siphonaptera: Ceratophyllidae). Revista del Instituto de Salubridad y Enfermedades Tropicales 20:27-35.

Vargas, M., And O. J. Polaco. 2001. Una nueva especie del genero Kleemannia (Gamasida: Ameroseiidae) asociada a
Dipodomys nelsoni (Rodentia: Heteromidae). Pp. 171-175 in Contribuciones Entomologicas. Homenaje a la Dra Isabel Bassols Batalla (Vargas, M., O. J. Polaco, and G. Zuñiga, eds.). Instituto Politecnico Nacional, Escuela Nacional de Ciencias Biológicas. Ciudad México, México.

Vargas-Sandoval, M., I. Bassols-Batalla, and O. J. Polaco. 1991. Un caso de mamíferos dispersores de acaros en Mexico. Anales de la Escuela Nacional de Ciencias Biológicas 35:117122.

Vargas, M., T. M. Pérez, and O. J. Polaco. 1999. The genus Geomylichus Fain (Acari: Listrophoridae) from Mexico, with descriptions of four new species. International Journal of Acarology 35:3-12.

Vargas, M., M. Garcia-Varela, J.P. Laclette, and T. M. Perez. 2005. Application if ITS-2 sequences as markers for identification and phylogenetic inference within the genus Geomylichus (Acari: Listrophoridae). Experimental and Applied Acarology 35:223-238.

WEBB JR., J.P., AND R. B. Loomis. 1971. The subgenus Scapuscutala of the genus Microtrombicula (Acarina: Trombiculidae) from North America. Journal of Medical Entomology 8:319-329.

WeBSter, M. S. 2017. The extended specimen: emerging frontiers in collections-based ornithological research. Studies in Avian Biology (no. 50), Boca Raton, Florida.

Wenzel, R. L., AND V. J. Tipton. 1966. Ectoparasites of Panama. Field Museum of Natural History. Illinois, U.S.A.

Werneck, F. L. 1952. Contribuição ao conhecimento dos anopluros. I. Revista Brasileira de Biologia 12:69-78.

WhItAKER JR., J. O. 1968. Parasites. Pp. 254-311 in Biology of Peromyscus (Rodentia; King, J. A., ed.). Special Publications No 2, The American Society of Mammalogists. Lawrence, U.S.A.

Whitaker JR., J. O., and J. E. Morales-Malacara. 2005. Ectoparasites and other associates (ectodytes) of mammals of Mexico. Pp. 535-666 in Contribuciones mastozoológicas en homenaje a Bernardo Villa (Sánchez-Cordero, V., and R. A. Medellín, eds.). Instituto de Biología, UNAM/Instituto de Ecología, UNAM/Conabio. Ciudad México, México.

Whitaker JR., J. O., J. I. Glendinning, and W. J. Wrenn. 1991. Ectoparasites of Sorex saussurei (Saussure's shrew) from Michoacan, Mexico. The Southwestern Naturalist 36:114-115.

WhitaKer JRo, J. O., W. J. WrenN, AND R. E. LeWIS. 1993. Parasites. Pp. 386-478 in Biology of the Heteromyidae (Genoways, $\mathrm{H}$. H., and J. H. Brown, eds.). Special Publications no 10, The American Society of Mammalogists. Lawrence, U.S.A.

WrenN, W. J. 1987. Key to larval Euschoengastia (Acari: Trombiculidae) in North America. Journal of Medical Entomology 24:221-228.

Wrenn, W. J., J. T. Baccus, And R. B. Loomis. 1976. Two new species of North American mites in the genus Euschoengastia (Acarina: Trombiculidae). Southwestern Naturalist 21:301309.

WrenN, W.J., AND R. B. Loomis. 1967. Otorhinophila, a new genus of chiggers (Acarina, Trombiculidae) from western North America. Acarologia 9:152-178.

Wrenn, W.L., AND R. B. Loomis. 1974. The Euschoengastia radfordi species complex (Acarina: Trombidulidae from western North America, with description of five new species. Annals of the Entomological Society of America 67:241-256. 
Wrenn, W. L., ANd R.E. Somerby. 1974. Descriptions of two new species of Euschoengastia (Acarina: Trombiculidae) from California and Baja California Norte, Mexico. Bulletin of the Southern California Academy of Science 73:5-8.

Zapata-Valdés, C., R. Avila-Flores, K. Gage, J. Holmes, J. MontenieRRI, M. Kosoy, AND G. SuzÁn. 2018. Mammalian hosts, vectors, and bacterial pathogens in communities with and without black-tailed prairie dogs (Cynomys ludovicianus) in northwestern Mexico. Journal of Wildlife Diseases 54:26-33.

Associated editor: Jesús Fernández

Submitted: March 14, 2019; Reviewed: April 28, 2019;

Accepted: December 20, 2019; Published on line: January 7, 2020. 